\title{
Supramolecular Recognition and Selective Protein Uptake by Penetrating Peptide Hybrids
}

\author{
Marisa Juanes †, Irene Lostalé-Seijo †, Juan R. Granjał \& Javier Montenegroł* \\ $†$ Centro Singular de Investigación en Química Biolóxica e Materiais Moleculares (CIQUS), Departamento de Química Orgánica, Universidade de Santiago \\ de Compostela, 15782 Santiago de Compostela, Spain. *e-mail: javier.montenegro@usc.es
}

\section{Table of Contents}

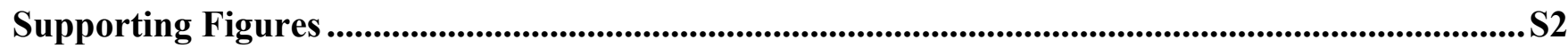

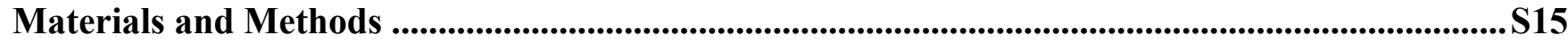

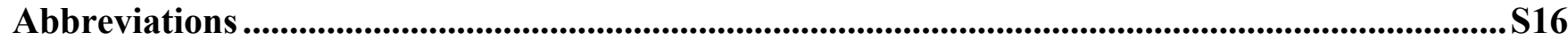

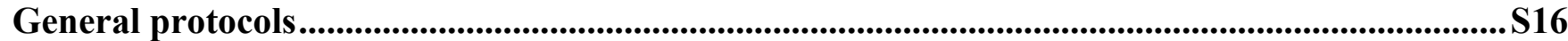

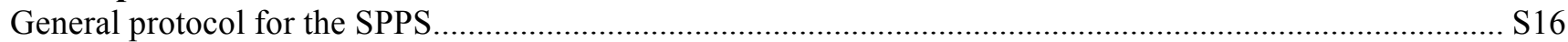

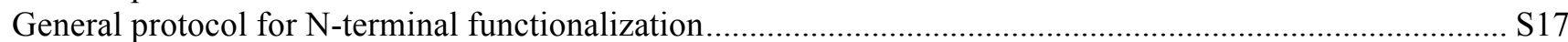

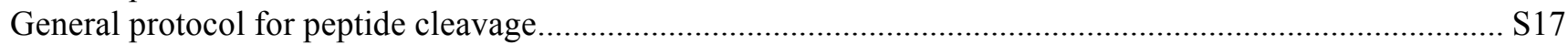

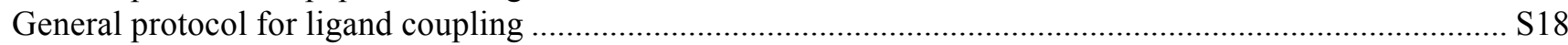

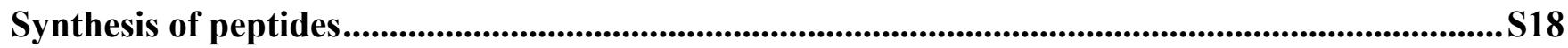

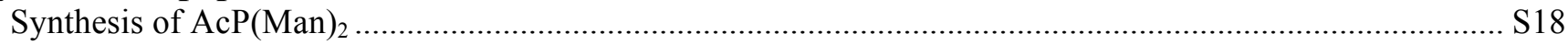

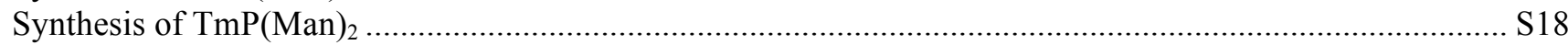

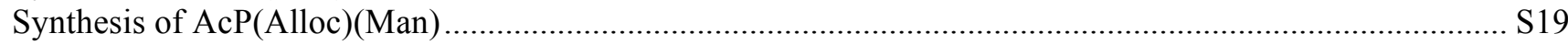

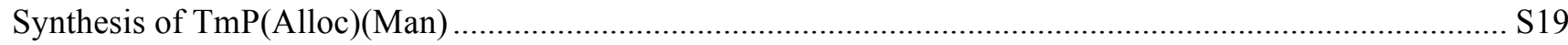

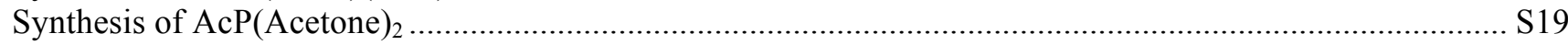

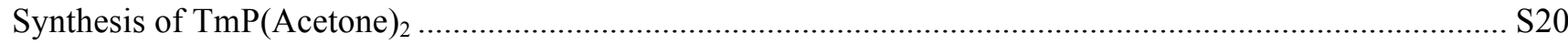

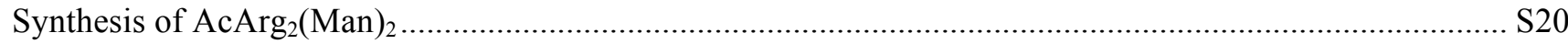

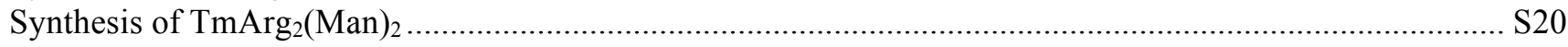

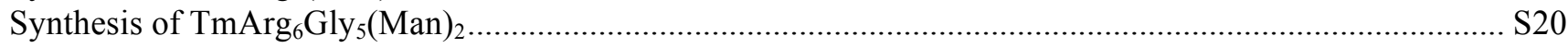

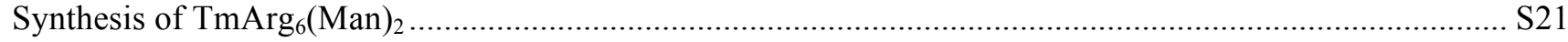

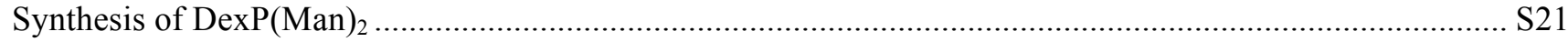

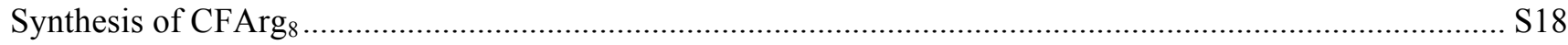

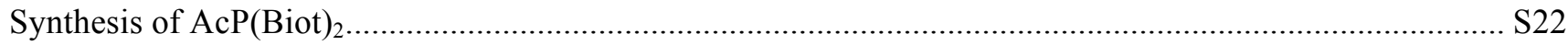

Preparation of Dexamethasone labelled Concanavalin A.............................................................S22

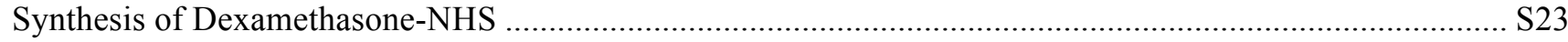

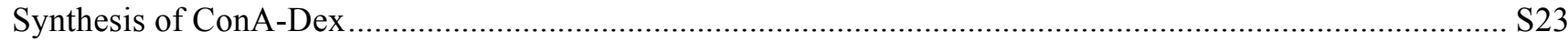

General Procedure for Circular Dichroism ..................................................................................S23

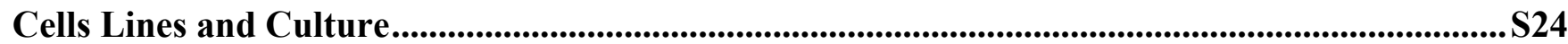

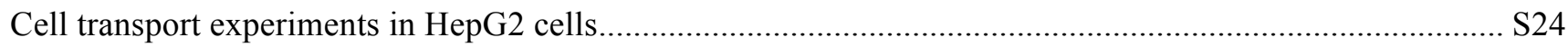

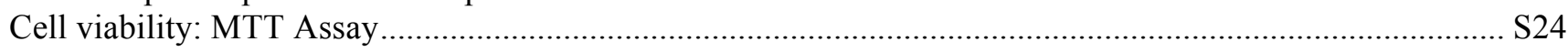

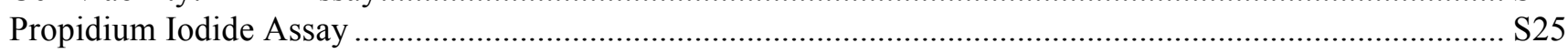

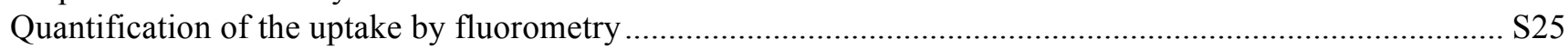

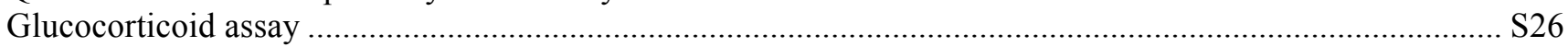

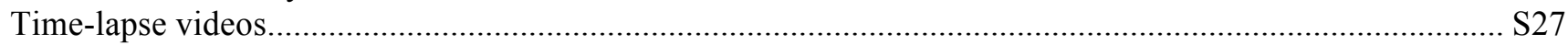

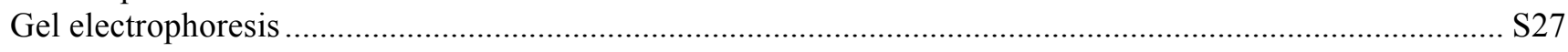

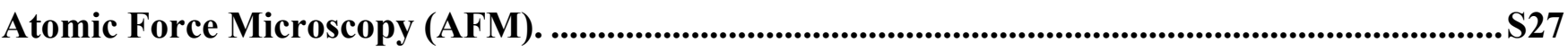

Supporting Figures for Characterization ............................................................................................S28

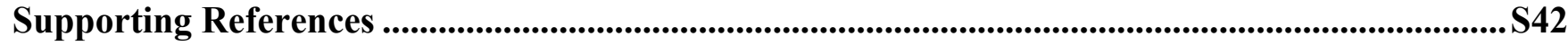



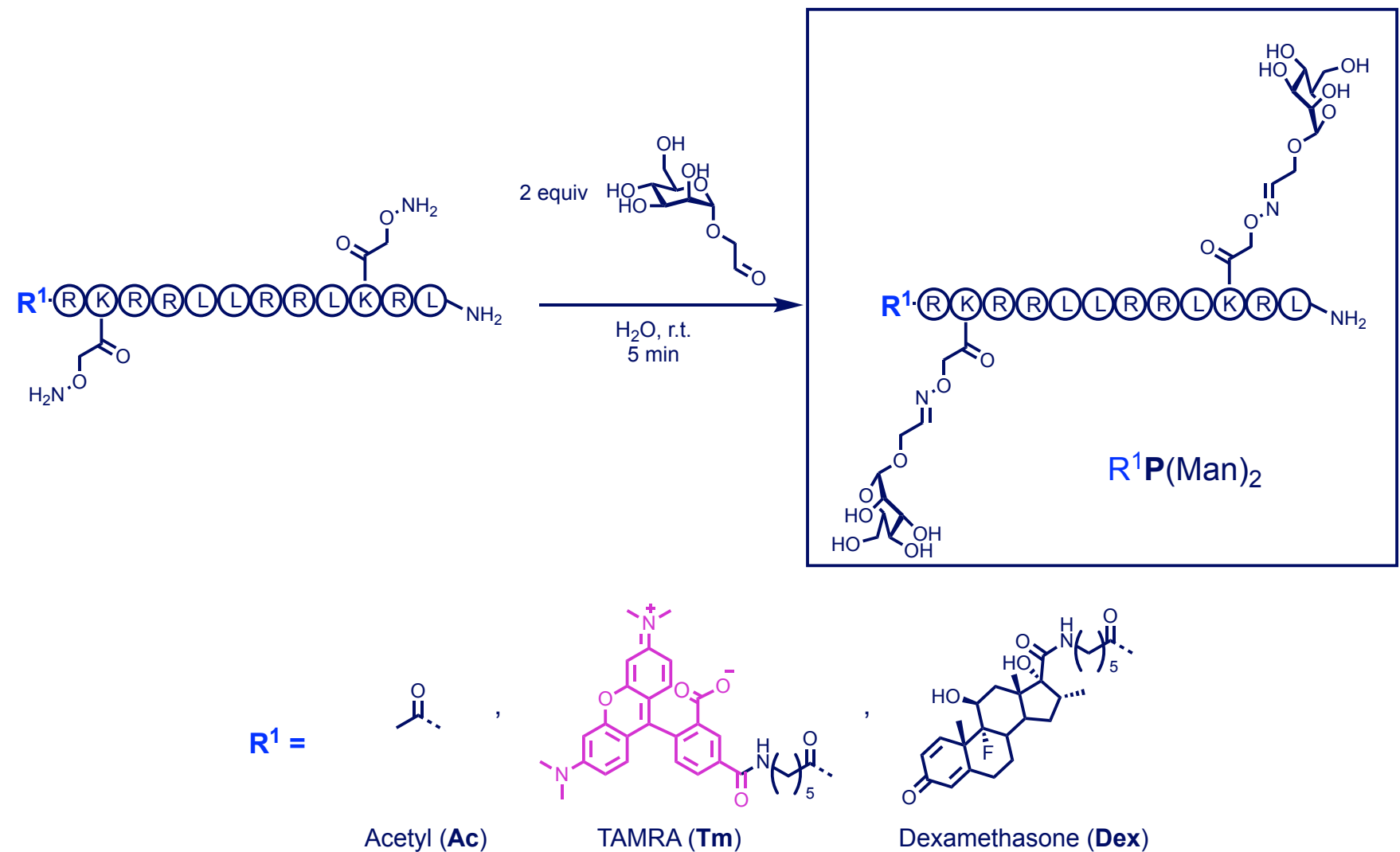

Figure S2. General synthetic scheme for the mannose aldehyde coupling. Peptides were obtained with an overall yield of: $28 \%$ for $\operatorname{AcP}(\operatorname{Man})_{2}, 5.6 \%$ for $\operatorname{TmP}(\operatorname{Man})_{2}$ and $5 \%$ for $\operatorname{DexP}(\operatorname{Man})_{2}$.

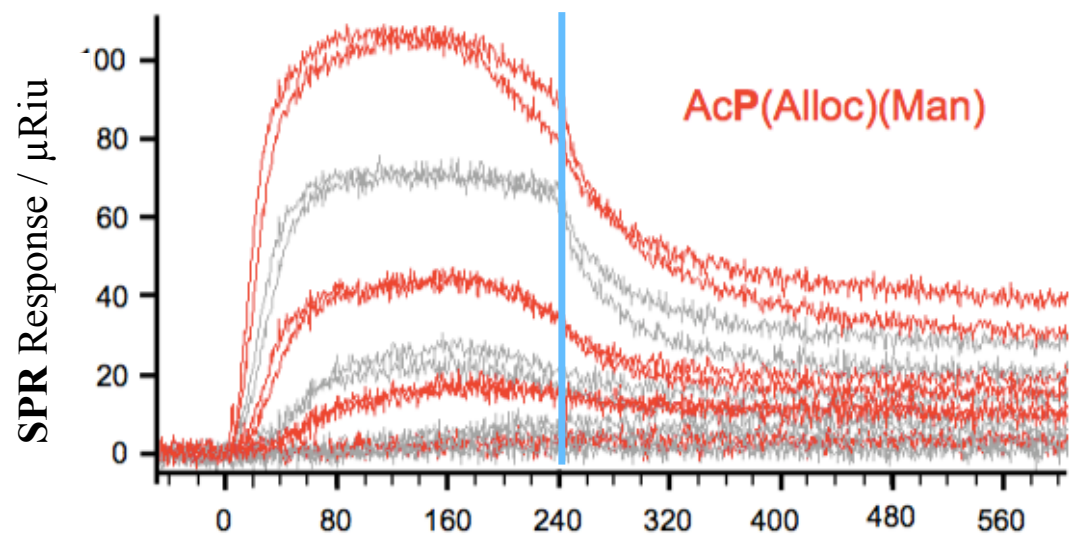

Time / seconds

Figure S3. SPR. Sensorgrams of the interaction of ConA (9668 $\mu$ RiU) in the concentration range $[$ AcP(Alloc)(Man) $]=6-2000 \mathrm{nM}$. 
A)

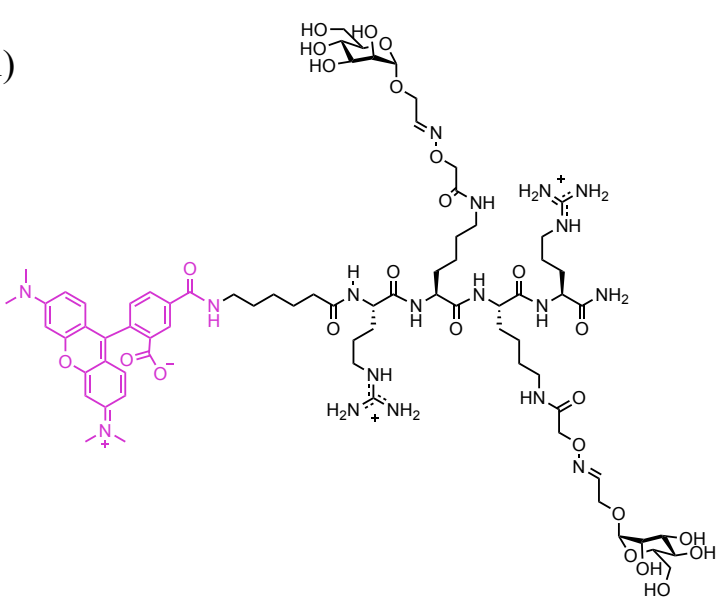

C)

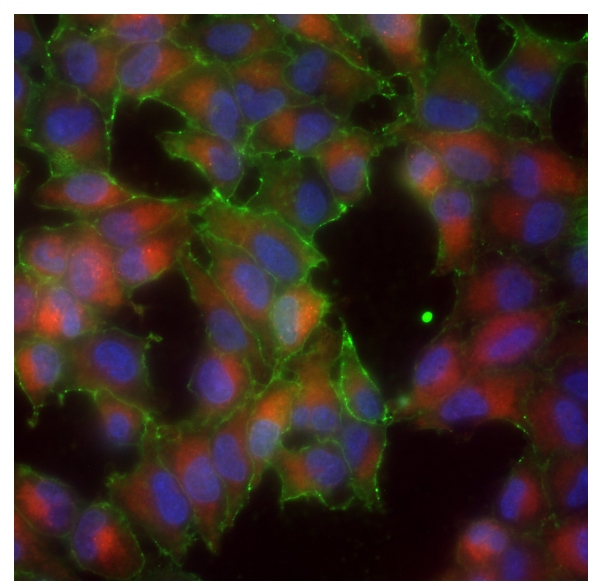

B)

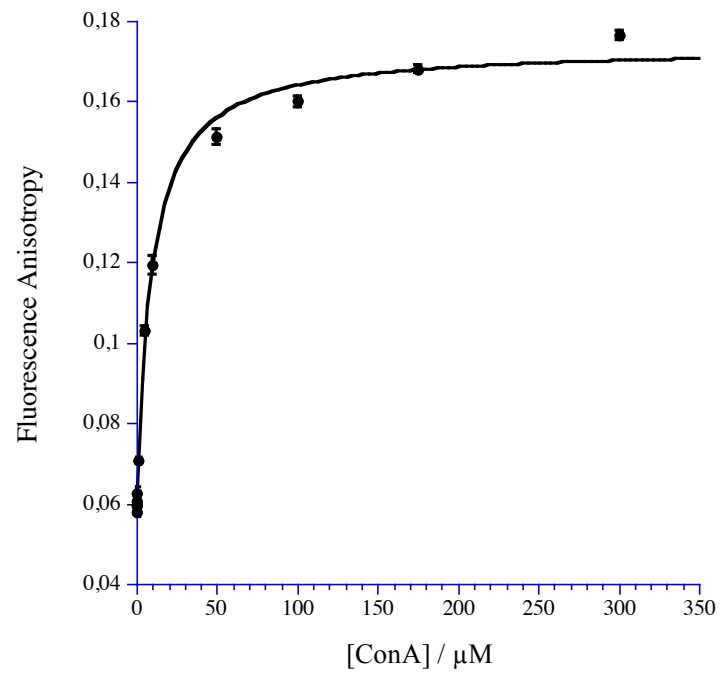

D)

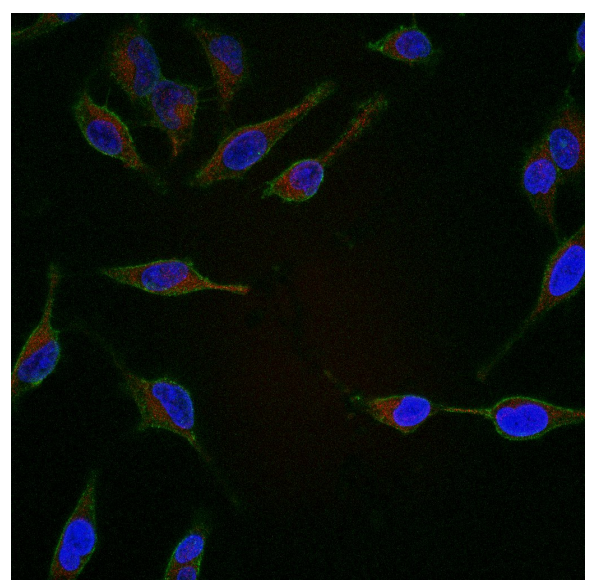

Figure S4. A) $\operatorname{TmArg}_{2}(\mathrm{Man})_{2}$ peptide structure. B) Fluorescence anisotropy titration and best fitting to a simple 1:1 binding model of $\operatorname{TmArg}_{2}(\mathrm{Man})_{2}$ with increasing amounts of ConA in HKR buffer (pH 7.4) at $22{ }^{\circ} \mathrm{C}$. Calculated $K_{\mathrm{d}}=9 \pm 1 \mu \mathrm{M}$. C) Epifluorescence and D) CLSM images of $\operatorname{TmArg}_{2}(\mathrm{Man})_{2}(3 \mu \mathrm{M}$, red $)$ treated with Con $\mathrm{A}_{\text {FITC }}(30 \mathrm{nM}$, green) and incubated with HeLa cells. Nuclei were counterstained with Hoechst (blue). 
A)

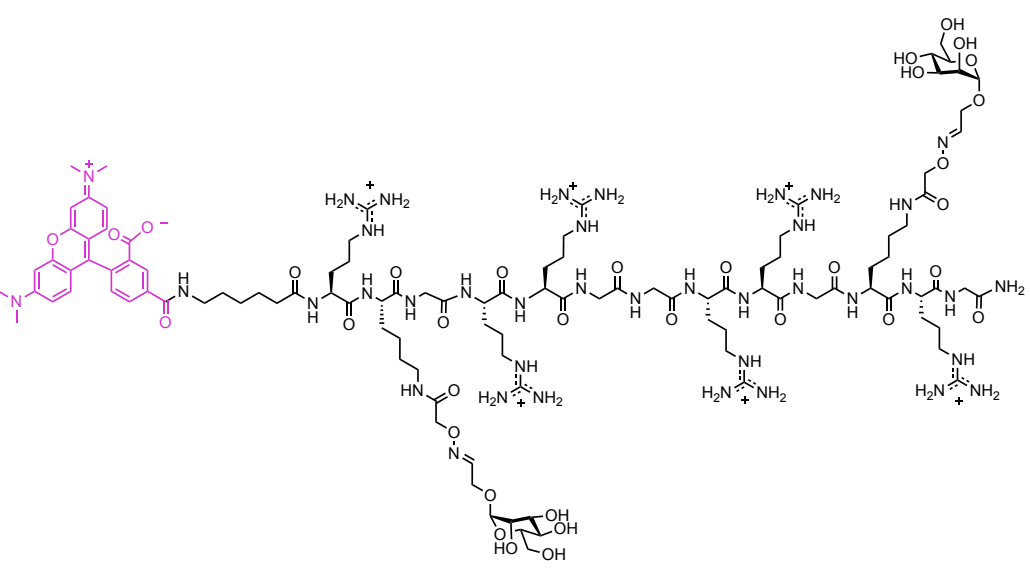

C)

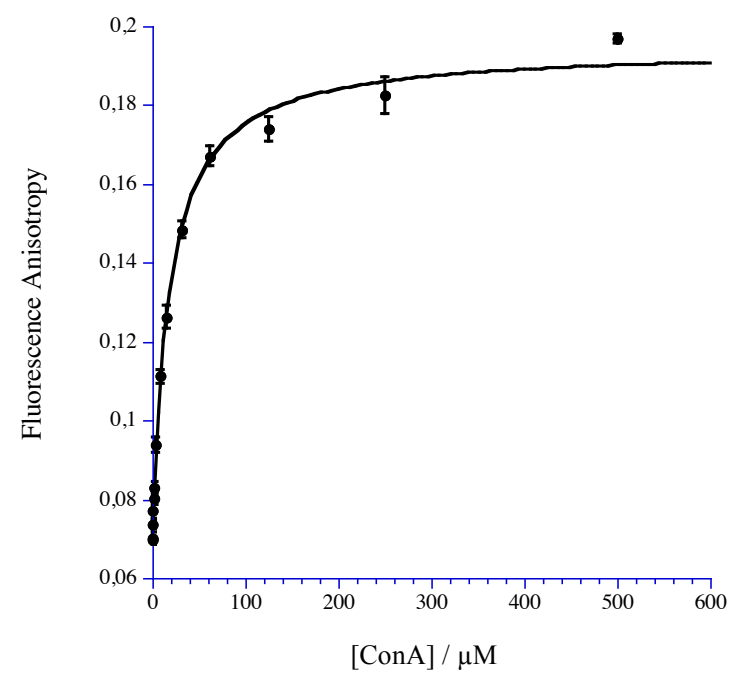

B)

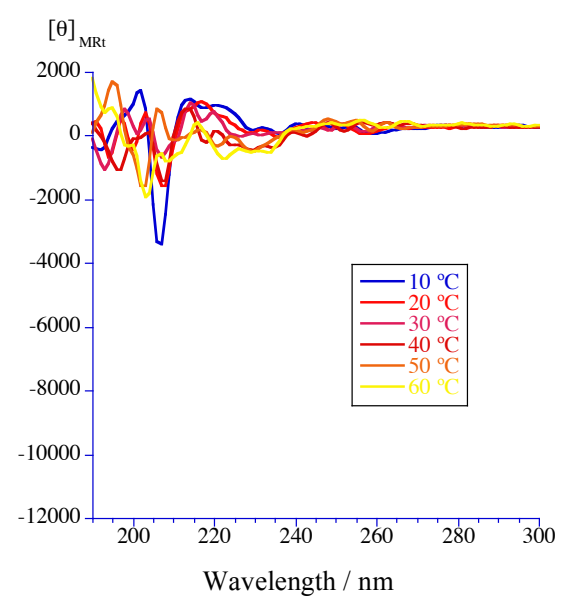

D)

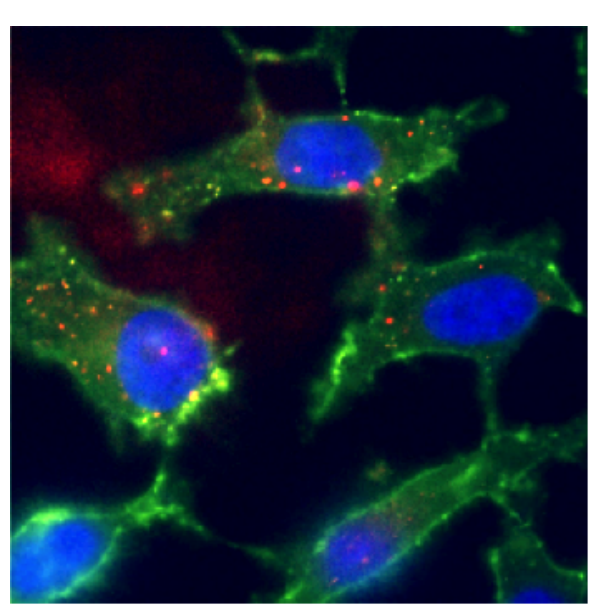

Figure S5. A) $\operatorname{TmArg}_{6} \mathrm{Gly}_{5}(\mathrm{Man})_{2}$ peptide structure. B) Circular dichroism of $\operatorname{TmArg}_{6} \mathrm{Gly}_{5}(\mathrm{Man})_{2}$ measured in HKR buffer at different temperatures. C) Fluorescence anisotropy titration and best fitting to a simple 1:1 binding model of $\operatorname{TmArg}_{6} \mathrm{Gly}_{5}(\mathrm{Man})_{2}$ with increasing amounts of ConA in HKR buffer (pH 7.4) at $22{ }^{\circ} \mathrm{C}$. Calculated $K_{\mathrm{d}}$ $=19 \pm 2 \mu \mathrm{M}$. D) Epifluorescence image of $\operatorname{TmArg}_{6} \mathrm{Gly}_{5}(\mathrm{Man})_{2}(3 \mu \mathrm{M}$, red $)$ treated with ConA $\mathrm{A}_{\text {FITC }}(30 \mathrm{nM}$, green $)$ and incubated with HeLa cells. Nuclei were counterstained with Hoechst (blue). 
A)

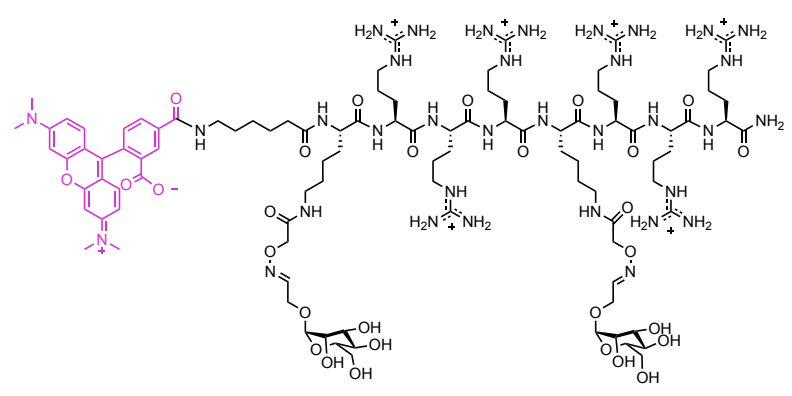

C)

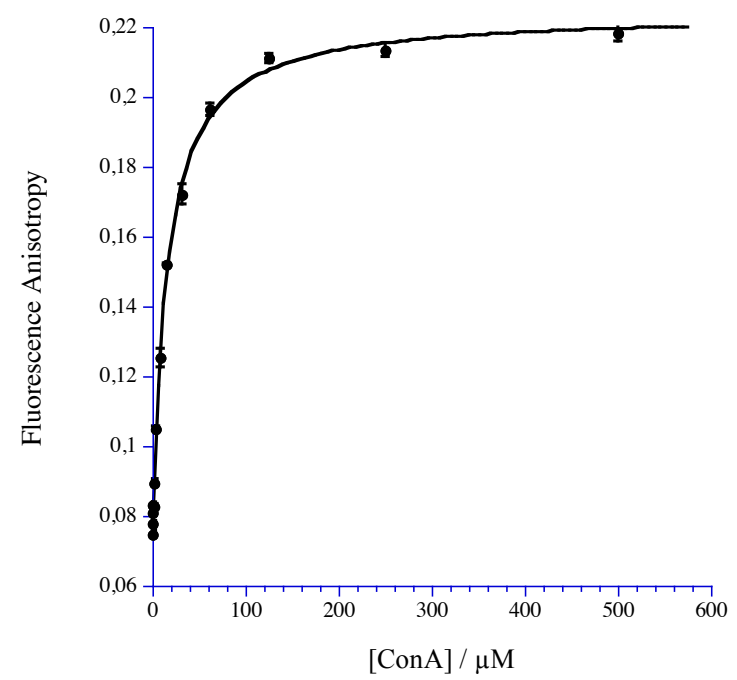

B)

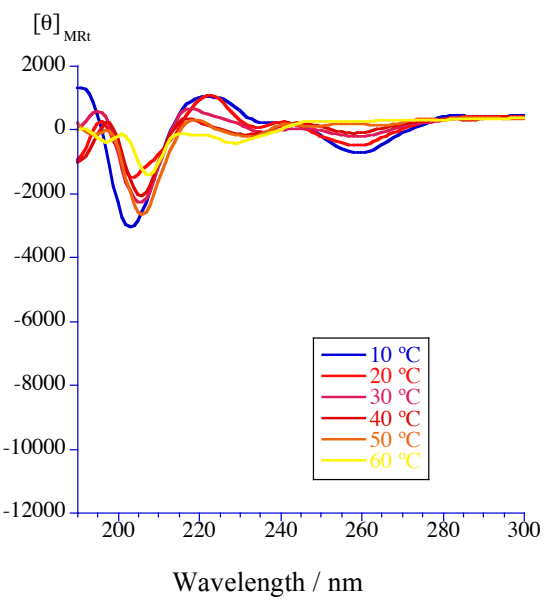

D)

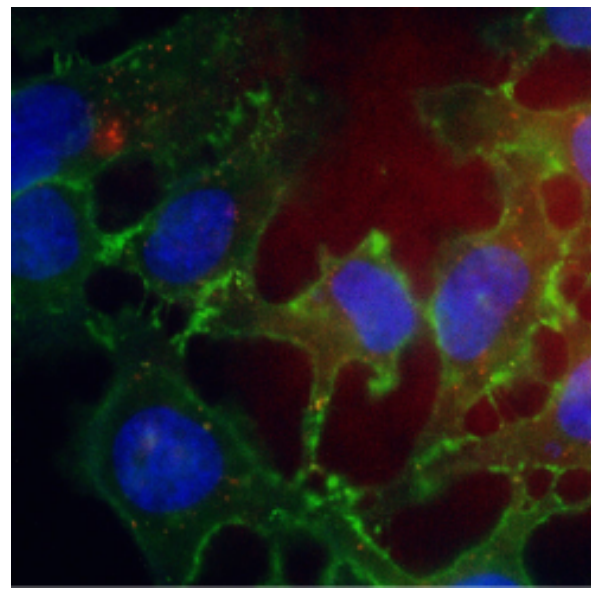

Figure S6. A) $\operatorname{TmArg}_{6}(\mathrm{Man})_{2}$ peptide structure. B) Circular dichroism of $\operatorname{TmArg}_{6}(\operatorname{Man})_{2}$ measured in HKR buffer at different temperatures. C) Fluorescence anisotropy titration and best fitting to a simple 1:1 binding model of $\operatorname{TmArg}_{6}(\mathrm{Man})_{2}$ with increasing amounts of ConA in HKR buffer $(\mathrm{pH} 7.4)$ at $22^{\circ} \mathrm{C}$. Calculated $K_{\mathrm{d}}=16 \pm$ $1 \mu \mathrm{M}$. D) Epifluorescence image of $\operatorname{TmArg}_{6}(\operatorname{Man})_{2}\left(3 \mu \mathrm{M}\right.$, red) treated with Con $\mathrm{A}_{\text {FITC }}(30 \mathrm{nM}$, green) and incubated with HeLa cells. Nuclei were counterstained with Hoechst (blue). 
A)

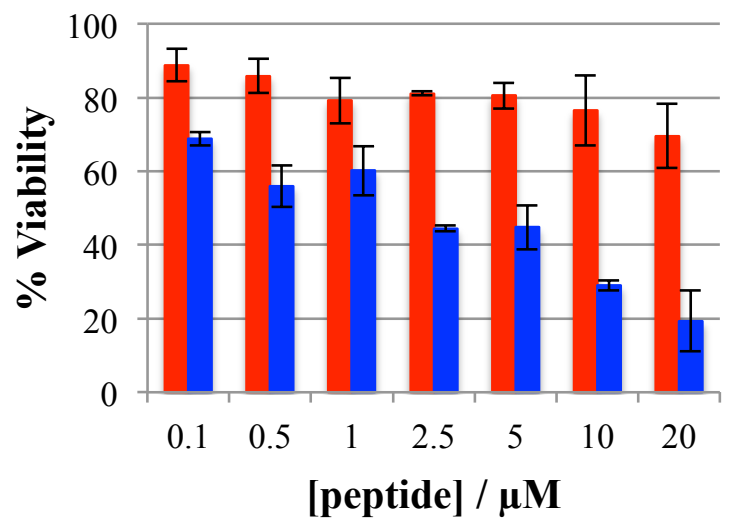

C)

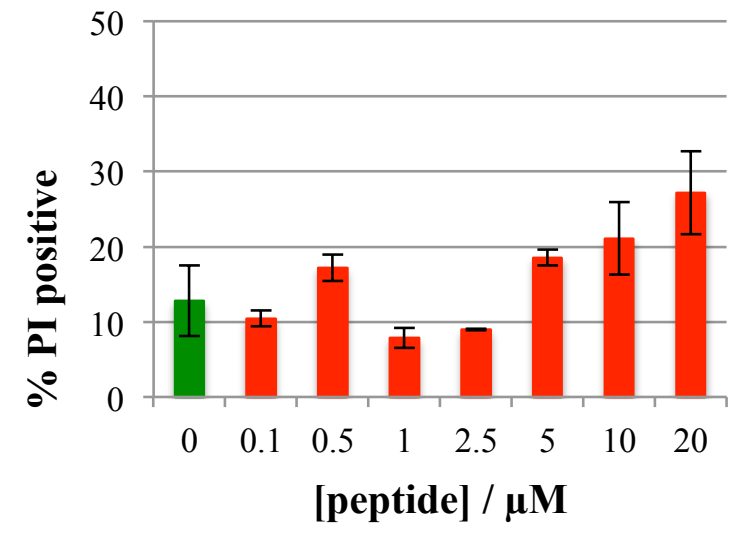

B)

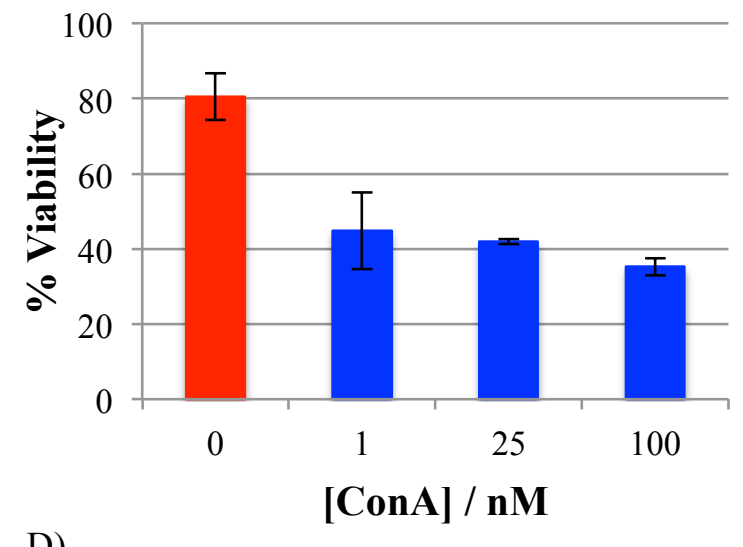

D)

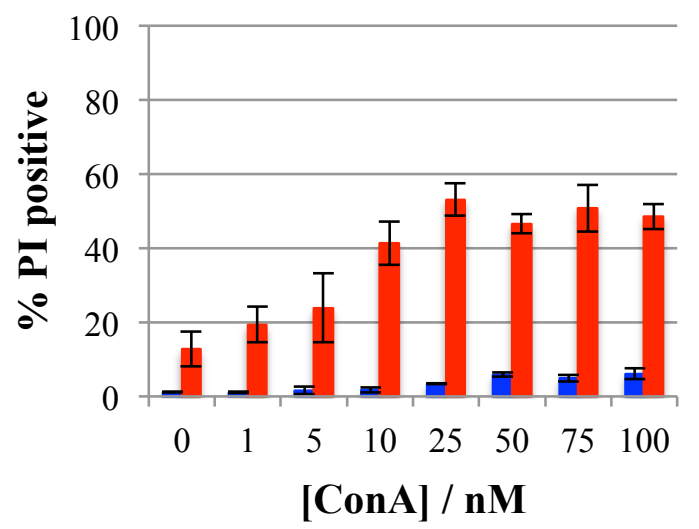

Figure S7. Cell viability in HeLa Cells. A) MTT assay at different concentrations of $\operatorname{AcP}(\mathrm{Man})_{2}$ (red) and $\mathrm{AcP}(\text { Acetone })_{2}$ (blue); B) MTT assay at different concentrations of ConA using $5 \mu \mathrm{M}$ of AcP(Man $)_{2}$, the viability for $\mathrm{AcP}(\mathrm{Man})_{2}$ alone is shown in red at $0 \mathrm{nM}$ of ConA; C) Propidium iodide staining of dead cells for flow cytometry at different concentrations of $\operatorname{AcP}(\operatorname{Man})_{2}$. The staining of untreated cells (control) is represented in green; D) Propidium iodide staining of dead cells for flow cytometry at different concentrations of ConA using 5 $\mu \mathrm{M}$ of $\mathrm{AcP}(\mathrm{Man})_{2}$ (red). Blue bars represent the cytotoxicity of the ConA alone. 
A)

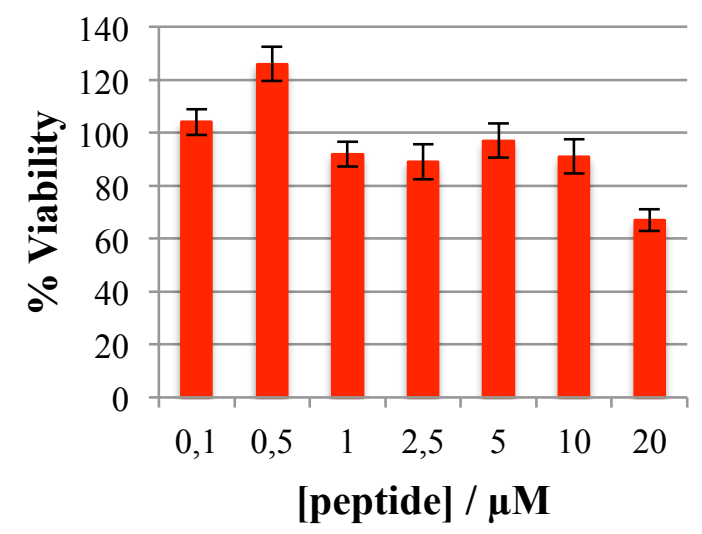

C)

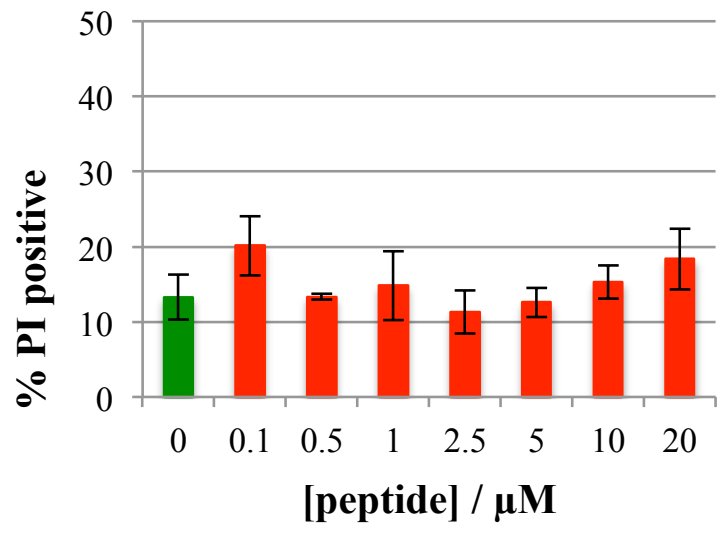

B)

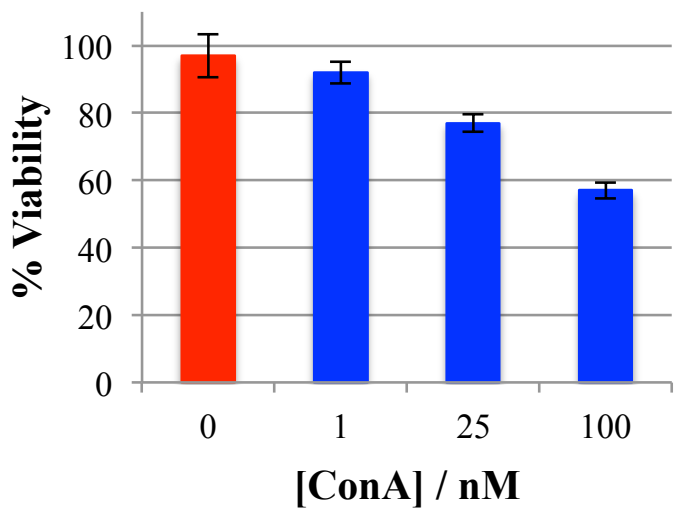

D)

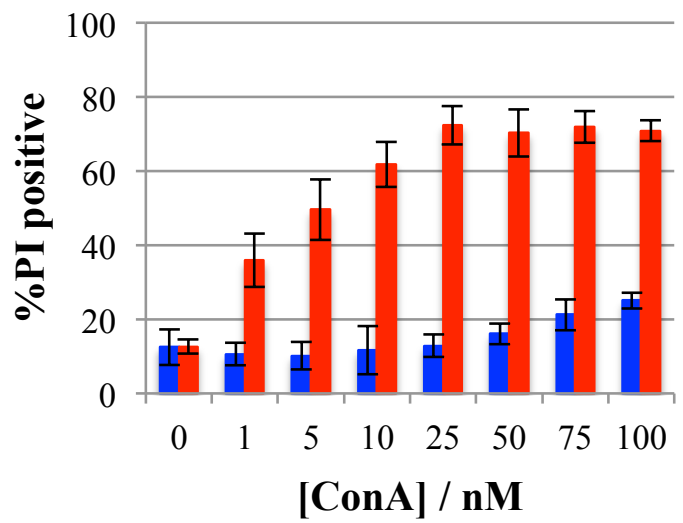

Figure S8. Cell viability in HepG2 Cells. A) MTT assay at different concentrations of $\mathrm{AcP}(\mathrm{Man})_{2}$ (red); B) MTT assay at different concentrations of ConA using $5 \mu \mathrm{M}$ of $\operatorname{AcP}(\operatorname{Man})_{2}$, the viability for $\operatorname{AcP}(\operatorname{Man})_{2}$ alone is shown in red at $0 \mathrm{nM}$ of ConA; C) Propidium iodide staining of dead cells for flow cytometry at different concentrations of $\mathrm{AcP}(\mathrm{Man})_{2}$. The staining of untreated cells (control) is represented in green; D) Propidium iodide staining of dead cells for flow cytometry at different concentrations of ConA using $5 \mu \mathrm{M}$ of $\mathrm{AcP}(\mathrm{Man})_{2}$ (red). Blue bars represent the cytotoxicity of the ConA alone. 


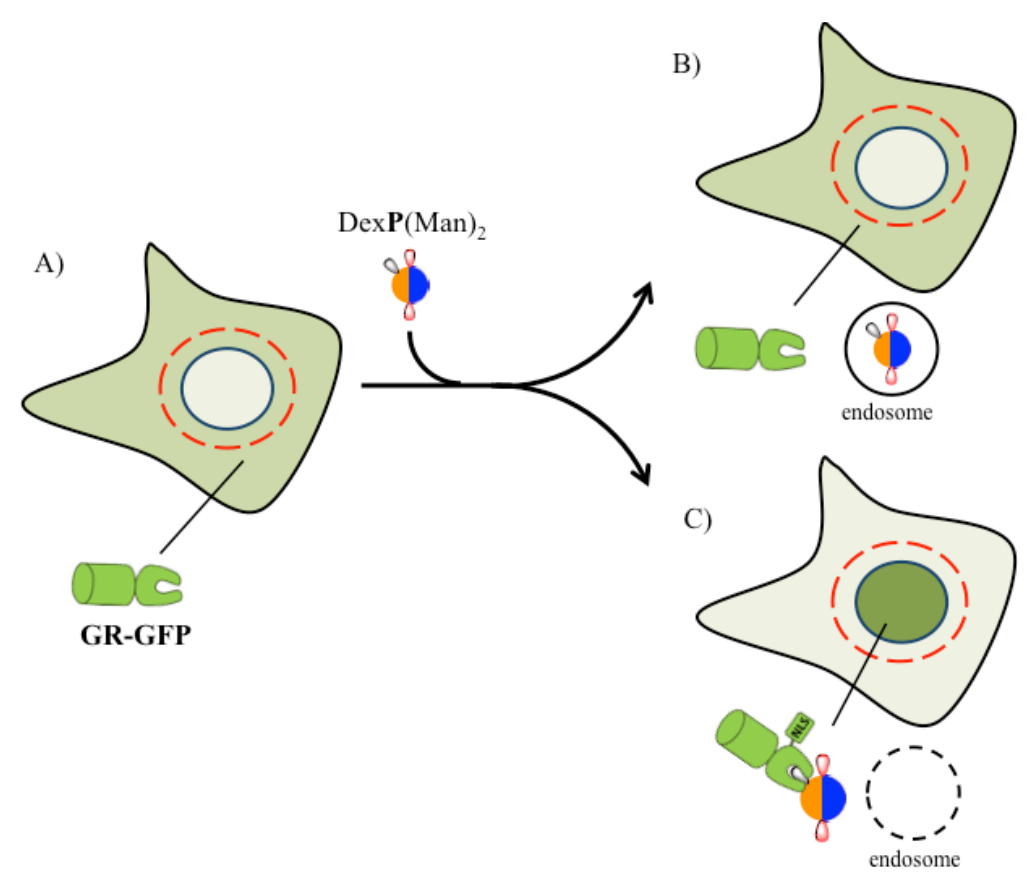

Figure S9. Glucocorticoid induced GFP translocation assay (GIGT). A) Cells transfected with the plasmid pK7GR-GFP show green fluorescence mostly on the cytoplasm, and so, the ratio between the median fluorescence in the nucleus and in the surrounding cytosolic region (red circle) will be low. Upon incubation with dexamethasone-labelled peptides, if the peptide remains trapped in the endosome (B) or it does not enter the cell, the glucocorticoid receptor will not be able to bind the dexamethasone and the translocation ratio will remain low. However, if the peptide is able to reach the cytosol, by direct translocation or endosomal escape (C), the binding to the glucocorticoid receptor triggers a conformational change that exposes NLSs. This causes the accumulation of GR-GFP in the nucleus and the increase in the translocation ratio.

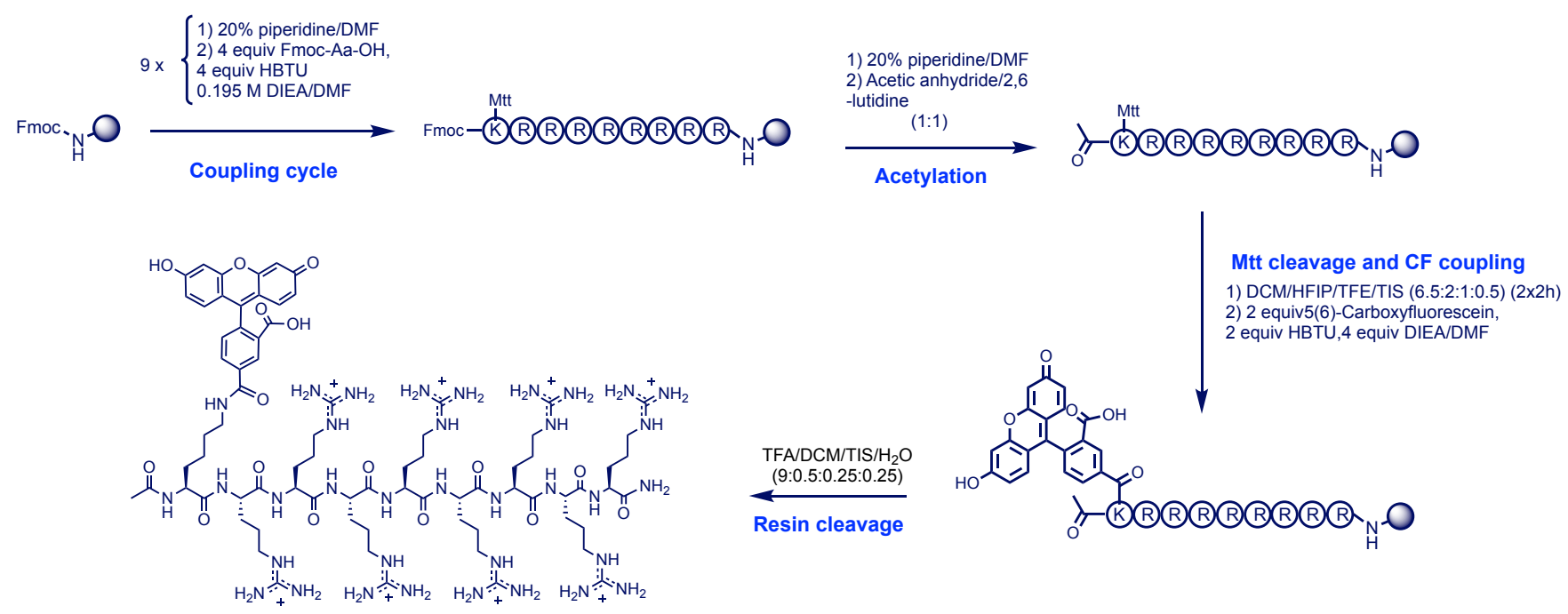

Figure S10. General synthetic scheme for the Solid Phase Peptide Synthesis (SPPS) for synthesizing the CFArg 8 peptide. 

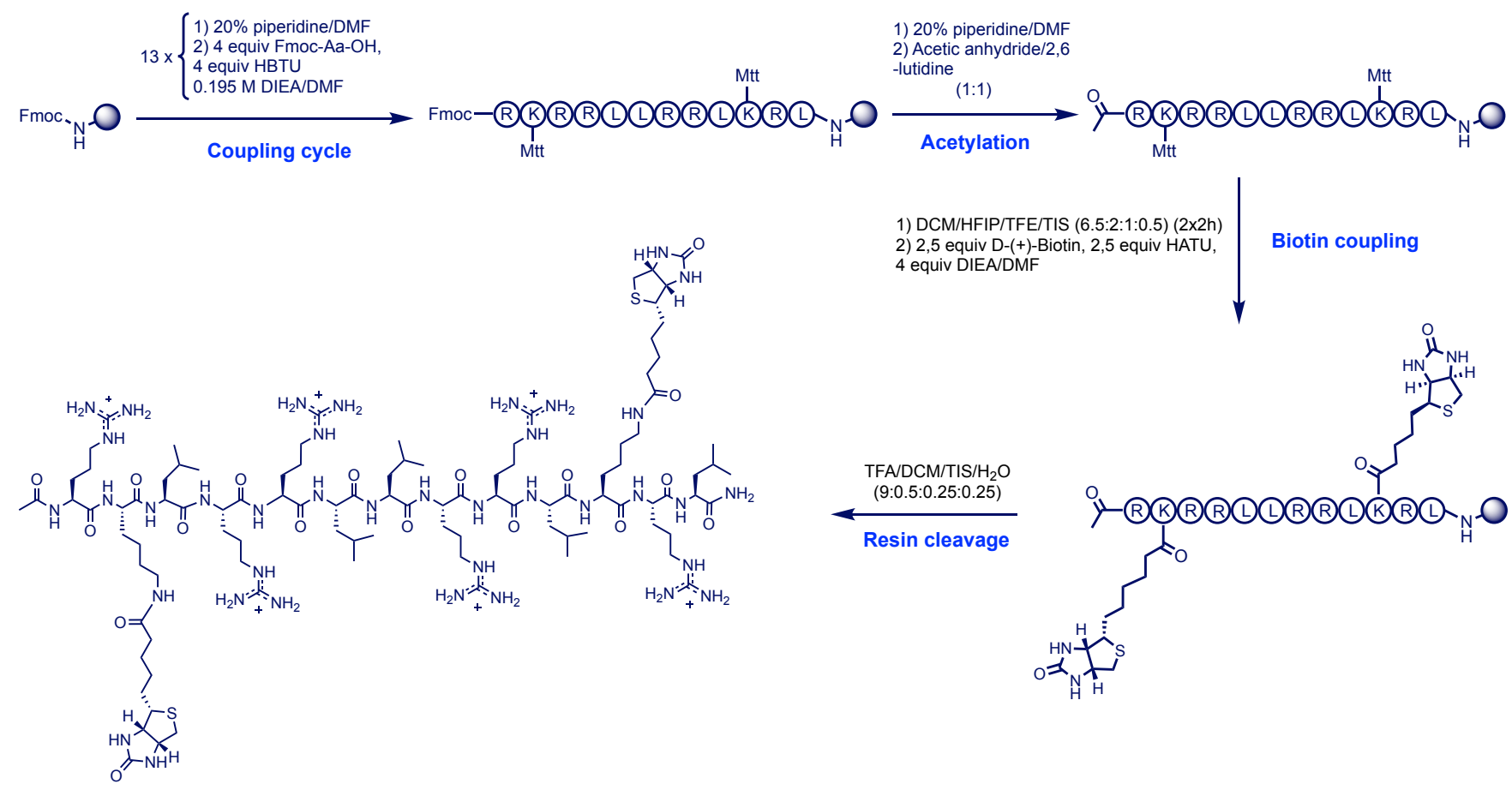

Figure S11. General synthetic scheme for the Solid Phase Peptide Synthesis (SPPS) for synthesizing the AcP(Biot $)_{2}$ peptide.

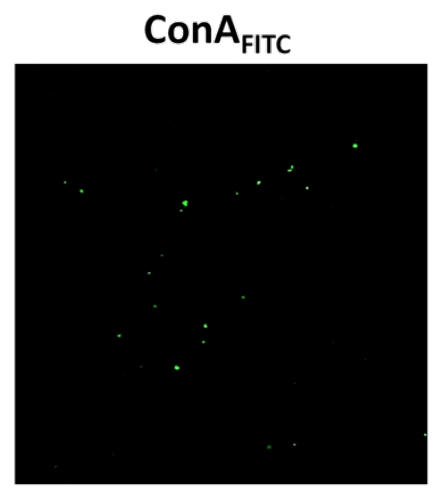

Streptavidin $_{594}$

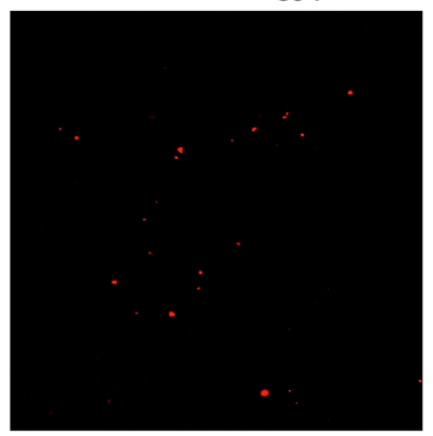

Merge

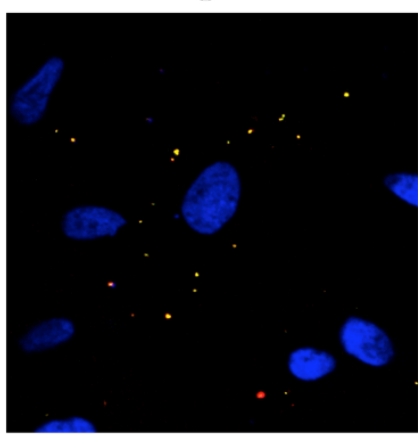

+DIC

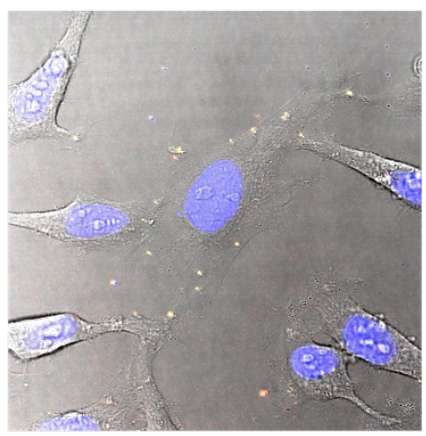

Figure S12. Lipofectamine is not a selective carrier. CLSM images of HeLa cells incubated with a mixture of 30 $\mathrm{nM}$ ConA $\mathrm{F}_{\mathrm{FITC}}, 30 \mathrm{nM}$ Streptavidin $_{594}$ and $2 \mathrm{ng} / \mu \mathrm{L}$ of Lipofectamine 2000 (protein/Lipofectamine complex formation was done by incubation in a tenth of the final volume for $20 \mathrm{~min}$ ) and incubated $30 \mathrm{~min}$ at $37^{\circ} \mathrm{C}$. Both proteins co-localize in punctate structures, located at the perifery of the cell. Nuclei were counterstained with Hoechst (blue). 


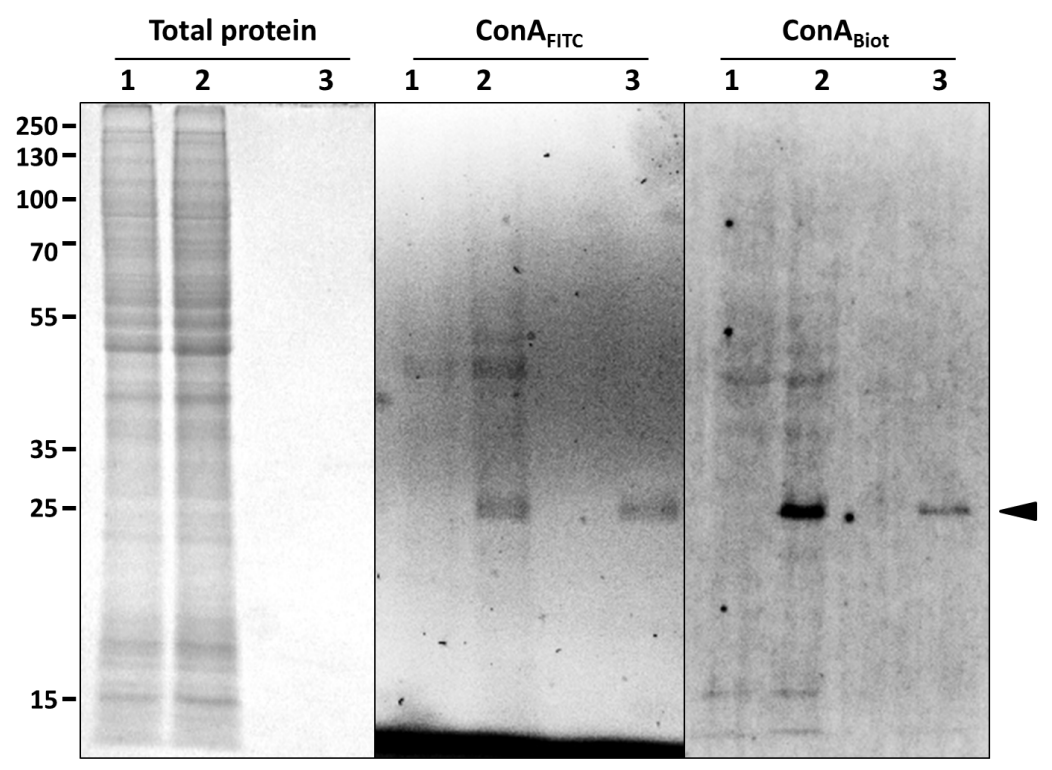

Figure S13. Gel electrophoresis to confirm integrity of the cargo after delivery. HeLa cells untreated (lane 1) or incubated with $3 \mu \mathrm{M}$ of $\mathrm{AcP}(\mathrm{Man})_{2}$ and $30 \mathrm{nM}$ of FITC- or biotin-labeled ConA (as indicated over the panels) (lane 2) for $30 \mathrm{~min}$ at $37{ }^{\circ} \mathrm{C}$ were washed, trypsinized and lysed, and proteins in the lysates resolved by SDSPAGE. A small amount of the original protein was loaded as a control (lane 3). ConA $\mathrm{A}_{\mathrm{FITC}}$ was imaged in the unfixed gel under UV light (ConA $\mathrm{A}_{\text {FITC }}$ panel) and afterwards the gel was fixed and stained with Coomassie Brilliant Blue to confirm that similar amounts of protein were loaded in lanes 1 and 2 (Total protein panel). ConA $_{\text {Biot }}$ was detected after protein transfer to PVDF membrane and incubation with Streptavidin 488 (Alexa Fluor$488)$. Arrowhead indicates the expected position of the ConA monomer ( $25 \mathrm{kDa})$. 


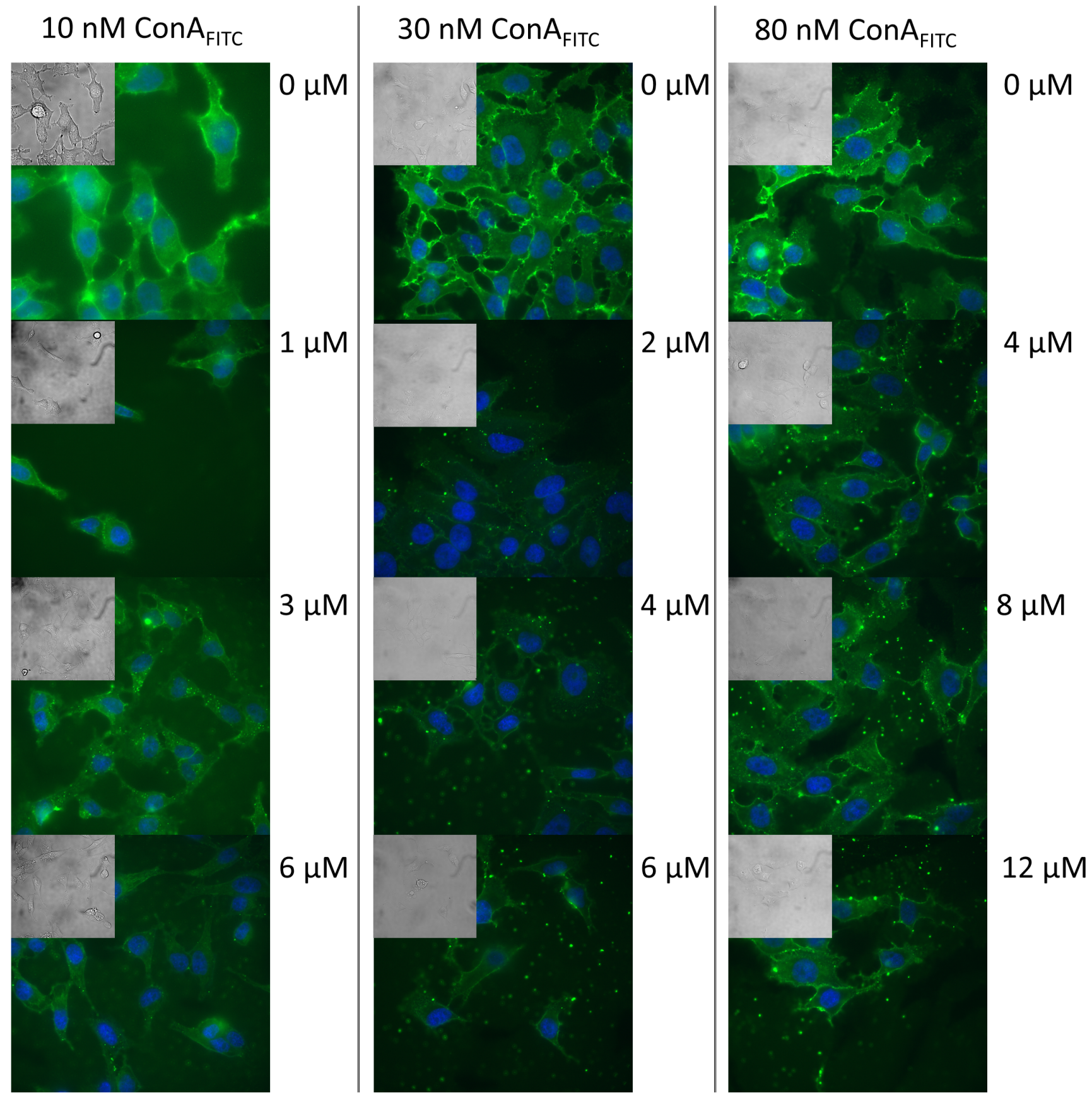

Figure S14. Importance of peptide/lectin ratio. Different amounts of Con $\mathrm{A}_{\mathrm{FITC}}$, as indicated above the panels, were incubated for $30 \mathrm{~min}$ with HeLa cells in the presence of the concentrations of $\mathrm{AcP}(\mathrm{Man})_{2}$ indicated at the right of the panels. Nuclei were counterstained with Hoechst (blue). 
A)
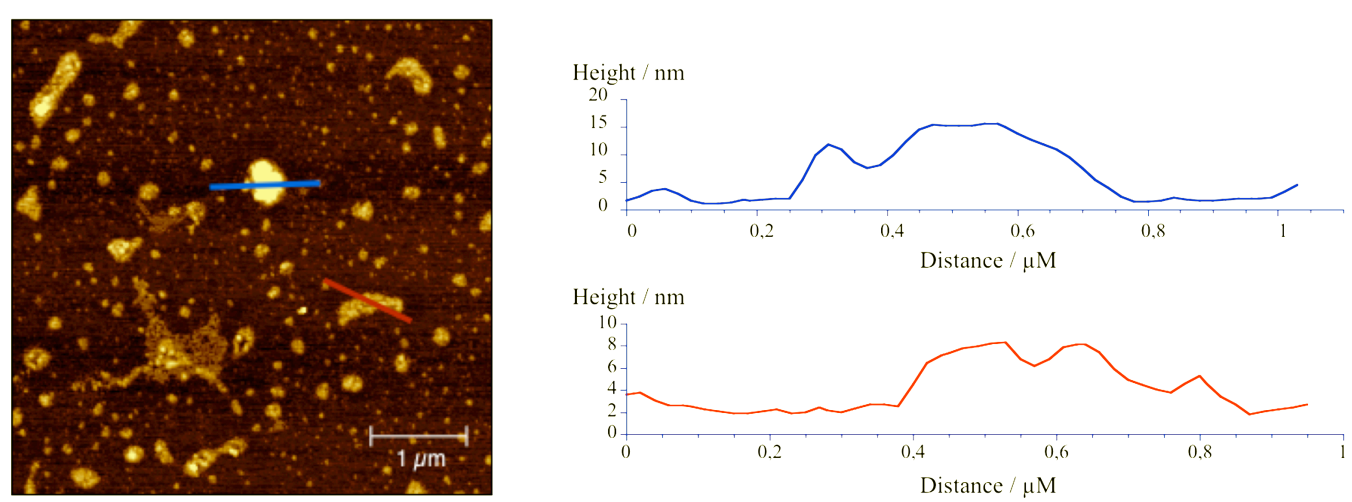

B)
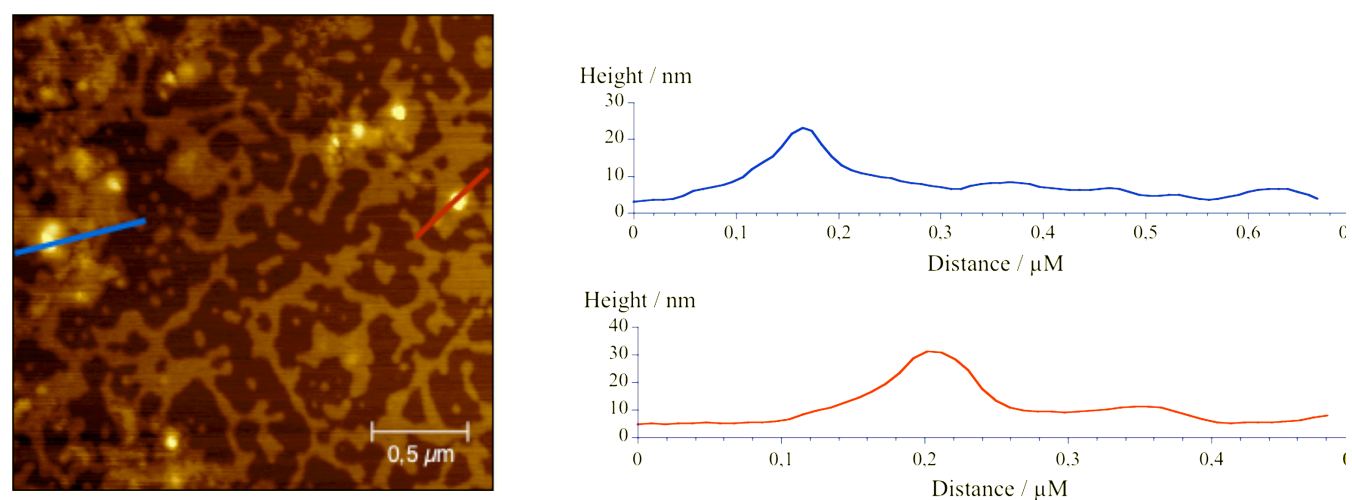

Figure S15. AFM topography images of $\mathrm{A}) \mathrm{AcP}(\operatorname{Man})_{2}(2 \mu \mathrm{M})$ and $\left.\mathrm{B}\right) \operatorname{AcP}(\mathrm{Man})_{2}(4 \mu \mathrm{M})$ with ConA $(30 \mathrm{nM})$ aqueous dispersions deposited on mica surface; images showed highly disperse aggregates. Dispersions prepared and deposited analogously as described in methods.
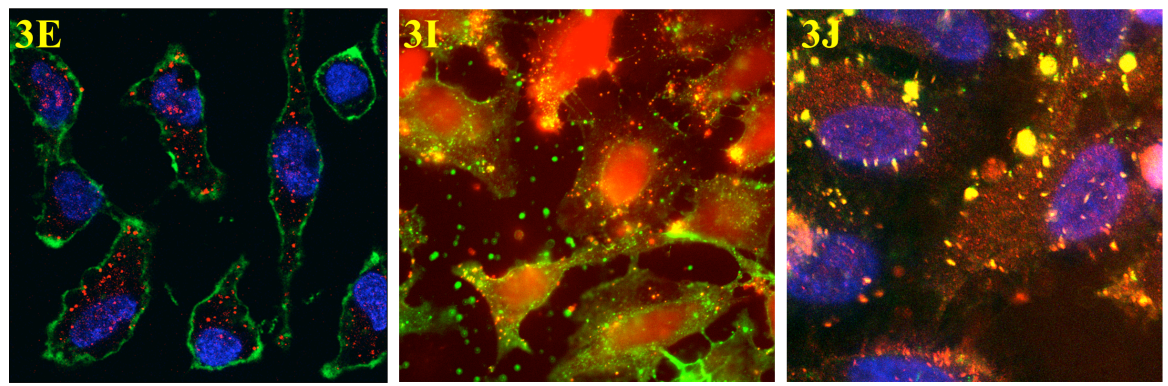

\begin{tabular}{|l|r|r|}
\hline Figure & Manders' tM $_{1}$ (Peptide) & Manders' tM $_{2}$ (Protein) \\
\hline 3E & 0.03 & 0.04 \\
\hline 3I & 0.52 & 0.64 \\
\hline 3J & 0.66 & 0.63 \\
\hline
\end{tabular}

Table S1. Co-localization parameters calculated for figures 3E, 3I, and 3J. 3E) CLSM image of CFArg 8 (red) and $\mathrm{ConA}_{647}$ (green); 3I) epifluorescence image of $\mathrm{TmP}(\mathrm{Man})_{2}$ (red) and $\mathrm{ConA}_{647}$ (green); 3J) CLSM image of

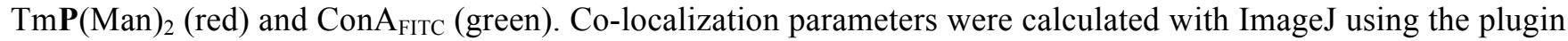
Coloc 2 and the Costes method for the estimation of the threshold. 


\begin{tabular}{|l|r|}
\hline Peptide & $K_{\mathrm{d}}$ \\
\hline TmP(Man) & \\
\hline $\operatorname{TmP}($ Alloc)(Man) & $14 \pm 1$ \\
\hline TmP(Acetone) ${ }_{2}$ & $27 \pm 4$ \\
\hline $\operatorname{TmArg}_{2}(\text { Man })_{2}$ & $151 \pm 7$ \\
\hline $\operatorname{TmArg}_{6} \mathrm{Gly}_{5}(\text { Man })_{2}$ & $9 \pm 1$ \\
\hline $\operatorname{TmArg}_{6}(\text { Man })_{2}$ & $19 \pm 2$ \\
\hline Methyl $\alpha$-D-mannopyranoside & $16 \pm 1$ \\
\hline
\end{tabular}

Table S2. Equilibrium dissociation constants obtained by fluorescence anisotropy after fitting to a simple 1:1 binding model.

Video S1. Internalization kinetics. To study the internalization kinetics, $\operatorname{TmP}(\mathrm{Man})_{2}(3 \mu \mathrm{M})$ and ConA $\mathrm{A}_{\text {FITC }}(30$ $\mathrm{nM}$ ) were incubated for $7 \mathrm{~min}$ in HKR to generate peptide/protein complexes. This solution was added to HeLa cells, previously washed with HKR, and the plate was immediately imaged on an epifluorescence microscope. Images for both peptide (red) and protein (green) channels were taken at intervals of $3 \mathrm{~min}$ for $20 \mathrm{~min}$. 


\section{Materials and Methods}

Commercially available Rink Amide-resin, $N$-HBTU, EDC and Fmoc- $L$-Lys(Mtt)-OH were used as obtained from Iris. [(tert-butoxycarbonyl)aminooxy]acetic acid, Chlorpromazine and Dexamethasone were purchased from TCI Chemicals. D-(+)-Biotin was used as obtained from Alfa Aesar. Dimethylaminopyridine, NHydroxysuccinimide, Fmoc-L-Gly-OH, Fmoc-L-Leu-OH, Fmoc-L-Arg(Pbf)-OH, Fmoc-6Ahx-OH, 5(6)Carboxyfluorescein, Concanavalin A from Canavalia ensiformis, Concanavalin A from Canavalia ensiformis (Jack bean) FITC conjugate, propidium iodide, Ammonium chloride, Chloroquine, Heparin sodium salt and 5-(NEthyl-N-isopropyl)amiloride were purchased from Sigma-Aldrich ${ }^{\circledR}$. 5(6)-Carboxytetramethlyrhodamine succinimidyl ester, 4-methylumbelliferyl- $\alpha-D$-mannopyranoside (4-MU- $\alpha$-D-Man) and Methyl- $\beta$-cyclodextrin were purchased from Carbosynth. Hoechst 33342 Trihydrochloride Trihydrate, Concanavalin A Alexa Fluor 647 conjugate, Lysotracker green DND-26, Streptavidin Alexa Fluor 594, Streptavidin Alexa Fluor 488, Lipofectamine 2000 and Coomassie (Bradford) protein assay kit were purchased in ThermoFisher. Wortmannin was obtained from Fluorochem. Egg yolk $L$ - $\alpha$-phosphatidylcholine (EYPC) was purchased from Avanti Polar Lipids, Inc. 1- $\alpha$-formylmethyl-mannopyranoside ${ }^{[1]}$, Ox-Dexamethasone $(\mathrm{Ox}-\mathrm{Dex})^{[2]}$ were synthesized according to protocols described in the literature ${ }^{1,2}$. Deuterated solvents $\left(\mathrm{D}_{2} \mathrm{O}\right.$ and $\left.\mathrm{CDCl}_{3}\right)$ were from EMD Millipore Corporation. $N, N$-Dimethylformamide, for peptide synthesis, was purchased from Scharlau. All the other solvents were HPLC grade, purchased from Sigma-Aldrich ${ }^{\circledR}$ or Fisher Scientific $^{\circledR}$, and used without further purification.

High-performance liquid chromatography coupled with mass spectrometry (HPLC-MS) analyses were carried out on Agilent Technologies 1260 Infinity II associated with a 6120 Quadrupole LC-MS using an Agilent SB-C18

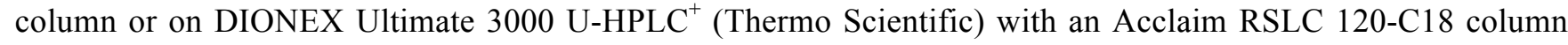
with Solvent A:Solvent $B$ gradients between 5:95 and 5:75 (Solvent $A$ : $\mathrm{H}_{2} \mathrm{O}$ with $0.1 \%$ TFA; Solvent B: $\mathrm{CH}_{3} \mathrm{CN}$ with $0.1 \%$ TFA). High-performance liquid chromatography (HPLC) preparative purification was carried out on Waters 1525 composed by a binary pump with a dual Waters 2489 detector with a Phenomenex Luna C18(2) 100A column. An Agilent 1200 with an Agilent Eclipse XDB-C18 column was used for semi-preparative purification using gradients between 5:95 and 5:75 (Solvent A: $\mathrm{H}_{2} \mathrm{O}$ with 0.1\% TFA; Solvent B: $\mathrm{CH}_{3} \mathrm{CN}$ with 0.1 \% TFA). Nuclear Magnetic Resonance (NMR) spectra were recorded on either a Varian Mercury $300 \mathrm{MHz}$ or a Varian Inova $500 \mathrm{MHz}$ spectrometer. Chemical shifts are reported in ppm ( $\delta$ units) referenced to the following solvent signals: $\mathrm{D}_{2} \mathrm{O} \delta \mathrm{H} 4.79$ and $\mathrm{CDCl}_{3} \delta \mathrm{H}$ 7.26. Spin multiplicities are reported as a singlet (s), doublet (d), triplet $(\mathrm{t})$ with coupling constants $(J$ ) given in Hz, or multiplet $(\mathrm{m})$. Accurate mass determinations (HR-MS) using ESI-MS were performed on a Sciex QSTAR Pulsar mass spectrometer and are reported as mass-per-charge ratio $(\mathrm{m} / \mathrm{z})$. Recalculation of the labelled peptides concentrations was performed by measuring the absorbance on a Dynamica HALO XB-10 UV-VIS Single Beam Spectrophotometer. Fluorescence measurements were performed with a FluoroMax-2 spectrofluorometer (Jobin-Yvon Spex) equipped with a stirrer and a temperature controller. Circular Dichroism (CD) measurements were performed with a Jasco J-1100 CD Spectrometer equipped with a Jasco MCB-100 Mini Circulation Bath. Cell microscopy images were acquired with an Andor Zyla 4.2 digital camera mounted on a Nikon Eclipse Ti-E epifluorescence microscope and with a Leica SP5 confocal microscope. 
Absorbance and fluorescence of cellular extracts were measured using a microplate reader Tecan Infinite F200Pro. Absorbance of labelled Concanavalin A was measured using a NanoDrop 1000 spectrophotometer. AFM images were acquired in a Park NX10 microscope in non-contact mode using ACTA silicon cantilevers with $37 \mathrm{~N} / \mathrm{m}$ nominal spring constant $(\mathrm{k})$ and $300 \mathrm{kHz}$ nominal resonance frequency.

\section{Abbreviations}

Peptide Abbreviations: TmP(Man $)_{2}(\mathrm{Tm}=$ TAMRA and Man $=$ Mannose aldehyde); Aa: Amino acid; AFM: Atomic Force Microscope; Arg: Arginine; BSA: Bovine Serum Albumin; Boc: tert-Butoxycarbonyl; Calcd: Calculated; CF: 5(6)-Carboxyfluorescein; CLSM: Confocal laser scanning microscopy; ConA: Concanavalin A; CPP: Cell-Penetrating Peptide; DCM: Dichloromethane; DIEA: N,N-Diisopropylethylamine; DMAP: 4Dimethylaminopyridine; DMEM: Dulbecco's Modified Eagle Medium; DMF: N,N-Dimethylformamide; DMSO: Dimethylsulfoxide; EDC: 1-Ethyl-3-(3-dimethylaminopropyl)carbodiimide hydrochloride; EIPA: 5-(N-Ethyl-Nisopropyl)amiloride; EYPC: Egg yolk phosphatidylcholine; FBS: Fetal Bovine Serum; Fmoc: 9fluorenylmethoxycarbonyl; GFP: Green Fluorescent Protein; GR-GFP: Glucocorticoid receptor-Green Fluorescent Protein; HFIP: 1,1,1,3,3,3-Hexafluoro-2-propanol; HKR: HEPES-Krebs-Ringer buffer; HRMS (ESI): High resolution mass spectrometry (electrospray ionization); Lys: Lysine; Mtt: 4-Methyltrityl; MTT: 3-(4,5dimethylthiazol-2-yl)-2,5-diphenyltetrazolium bromide; $N$-HATU: N-[(Dimethylamino)-1H-1,2,3-triazolo[4,5b]pyridin-1-ylmethylene]-N-methylmethanaminiun hexafluorophosphate $\quad \mathrm{N}$-oxide; $\quad N$-HBTU: $\quad \mathrm{N}-[(1 \mathrm{H}-$ Benzotriazol-1-yl)4-(dimethylamino)methylene]-N-methylmethanaminium hexafluorophosphate N-oxide; NHS: N-Hydroxysuccinimide; NLS: nuclear localization signal; Ox: Oxime; Ox-Dex: Dexamethasone Acid; Pbf: 2,2,4,6,7-Pentamethyldihydrobenzofuran-5-sulfonyl; PI: propidium iodide; RP: Reverse Phase; SPPS: Solid Phase Peptide Synthesis; TAMRA: 5(6)-Carboxytetramethlyrhodamine succinimidyl ester; TFE: Trifluoroethanol; TIS: Triisopropylsilane; TNBS: 2,4,6-Trinitrobenzenesulfonic acid; 6Ahx: 6-aminohexanoic acid.

\section{General protocols}

\section{General protocol for the SPPS}

All peptides were synthesized by manual Fmoc solid-phase peptide synthesis ${ }^{[3]}$ using Rink Amide resin (loading $0.71 \mathrm{mmol} / \mathrm{g})$. The resin $(0.1 \mathrm{mmol})$ was swelled in DMF (peptide synthesis grade, $2 \mathrm{~mL}$ ) for 20 min in a peptide synthesis vessel prior synthesis. Coupling cycle consisted of the removal of Fmoc protecting group with a solution of piperidine in DMF $(20 \%, 2 \mathrm{~mL})$ for $10 \mathrm{~min}$ and then the mixture was filtered and the resin was washed with DMF ( $3 \times 2 \mathrm{~mL}, 1 \mathrm{~min})$. The amino acid coupling was carried out by treatment with a solution of $\alpha$ amino acids (4 equiv), $N$-HBTU (3.95 equiv) in DMF (2 mL), which was mixed with DIEA (0.195 M solution in DMF, 1.2 equiv) $1 \mathrm{~min}$ before the addition and the resulting mixture was shaken by bubbling Ar for 15 min. Finally, the resin was washed with DMF $(3 \times 2 \mathrm{~mL}, 1 \mathrm{~min})$. The efficiency of each amino acid coupling and deprotection was monitored employing the TNBS test ${ }^{[4]}$. 
Once the linear peptide was finished, two different ending protocols were used:

A) Acetylation: the acetylation capping of N-terminal group was performed by standard Fmoc removal conditions (20\% piperidine in DMF) followed by treatment with a solution of acetic anhydride and 2,6lutidine $(1: 1,1 \mathrm{~mL})$ for $30 \mathrm{~min}$.

B) Linker coupling: after Fmoc cleavage with piperidine/DMF (20\%, $2 \mathrm{~mL})$, the linear peptide was treated with a solution of N-Fmoc-6-aminohexanoic acid (4 equiv), $N$-HBTU (3.95 equiv) and DIEA (0.195 M solution in DMF, 1.2 equiv) in DMF.

The resin was washed with DCM (2 x $2 \mathrm{~mL}, 5 \mathrm{~min})$, and the Mtt protecting group was selectively removed by mechanical shaking of the resin with a mixture of DCM/HFIP/TFE/TIS (6.5:2:1:0.5, 2 x $2 \mathrm{~mL}, 2 \mathrm{~h})$. Finally, the mixture was filtered and the resin was washed with DCM $(2 \times 2 \mathrm{~mL}, 2 \mathrm{~min})$ and DMF (2 mL, $20 \mathrm{~min})$. A solution of [(tert-butoxycarbonyl)aminooxy]acetic acid (2.5 equiv per free amine) and $N$-HATU (2.5 equiv) in DMF (1 $\mathrm{mL}$ ) was added to the resin followed by the dropwise addition of a solution of DIEA (4 equiv) in DMF (0.5 mL). The resin was shaken by bubbling Ar for $30 \mathrm{~min}$ and finally washed with DMF ( 3 x $2 \mathrm{~mL}, 2 \mathrm{~min})$ and DCM ( $3 \mathrm{x}$ $2 \mathrm{~mL}, 2 \mathrm{~min})$.

\section{General protocol for $\mathbf{N}$-terminal functionalization}

Fluorescently labelled peptides, the Fmoc-protecting group of the previously attached linker was removed by using a solution of piperidine in DMF $(20 \%, 4 \mathrm{~mL})$ for $15 \mathrm{~min}$ and the resin was washed with DMF $(3 \times 3 \mathrm{~mL})$. The coupling was carried out by the addition of a solution of 5(6)-Carboxytetramethylrhodamine succinimidyl ester (1 equiv) and DIEA (0.195 M, 1 equiv) in DMF ( $2 \mathrm{~mL})$ and the mixture was stirred by bubbling Ar for 30 min. Finally, the resin was washed with DMF $(3 \times 3 \mathrm{~mL})$ and DCM $(3 \times 3 \mathrm{~mL})$.

Ox-Dex terminating peptide, the Fmoc-protecting group of the linker was removed by using a solution of piperidine in DMF $(20 \%, 4 \mathrm{~mL})$ during $15 \mathrm{~min}$ and the resin was washed with DMF $(3 \times 3 \mathrm{~mL})$. A solution of Ox-Dex (3 equiv), $N$-HATU (2.9 equiv) and DIEA (0.195 M, 3 equiv) in DMF ( $2 \mathrm{~mL})$ was added and the mixture was shaken by bubbling Ar for 30 min. Finally, the resin was washed with DMF $(3 \times 3 \mathrm{~mL})$ and DCM $(3 \times 3$ $\mathrm{mL})$.

\section{General protocol for peptide cleavage}

Finally, peptides were deprotected and cleaved from the resin by standard TFA cleavage procedure at rt by using TFA/DCM/ $\mathrm{H}_{2} \mathrm{O} /$ TIS (90:5:2.5:2.5, $1 \mathrm{~mL}$ per $70 \mathrm{mg}$ of resin) for $2 \mathrm{~h}$. Then, the mixture was filtered, washed with TFA $(1 \mathrm{~mL})$ and the peptide was precipitated with ice-cold $\mathrm{Et}_{2} \mathrm{O}(25 \mathrm{~mL})$. The precipitate was centrifuged and dissolved in $\mathrm{H}_{2} \mathrm{O}(5 \mathrm{~mL})$.

Peptides were obtained following the previously described procedure, and were treated with the different ligands without purification. 


\section{General protocol for ligand coupling}

A solution of peptide $\left(\mathrm{R}^{1} \mathbf{P}(\mathrm{Ox})_{2}\right)$ in $\mathrm{H}_{2} \mathrm{O}(5 \mathrm{mM})$ was reacted with a solution of corresponding ligands (2 equiv per alkoxyamine) [1- $\alpha$-formylmethyl-mannopyranoside or acetone] in $\mathrm{H}_{2} \mathrm{O}(120 \mathrm{mM})$ for $5 \mathrm{~min}$. Then, peptides were purified by RP-HPLC for removing the ligand excess.

The purification was carried by a C18 RP-HPLC [Phenomenex Luna C18(2) 100A column, $\mathrm{H}_{2} \mathrm{O}(0.1 \%$ TFA)/ $\mathrm{CH}_{3} \mathrm{CN}(0.1 \%$ TFA) 95:5 $\rightarrow 5: 95(0 \rightarrow 5 \mathrm{~min}), 95: 5 \rightarrow 5: 95(5 \rightarrow 35 \mathrm{~min})]$ with a binary gradient of Solvent $A$ and Solvent $B$, the collected fractions were lyophilized and stored at $-20{ }^{\circ} \mathrm{C}$. Purity and identity were confirmed by analytical HPLC, ${ }^{1} \mathrm{H}-\mathrm{NMR}$ and low and high resolution mass spectrometry.

\section{Synthesis of peptides}

\section{Synthesis of AcP(Man)}

Following the general protocol of the SPPS for synthesizing an acetylated peptide with two mannoses, $\mathrm{AcP}(\mathrm{Man})_{2}$ was obtained after RP-HPLC purification [Phenomenex Luna C18(2) 100A column, $\mathrm{H}_{2} \mathrm{O}(0.1 \%$ TFA)/ $\mathrm{CH}_{3} \mathrm{CN}(0.1 \%$ TFA) $95: 5 \rightarrow 5: 95(0 \rightarrow 5 \mathrm{~min}), 95: 5 \rightarrow 5: 95(5 \rightarrow 35 \mathrm{~min})]$ with an overall yield of $28 \%$ and 99.3\% purity. $R_{\mathrm{t}} 3.8 \mathrm{~min}$ (Fig. S16) [RP-HPLC Agilent SB-C18 column, $\mathrm{H}_{2} \mathrm{O}(0.1 \% \mathrm{TFA}) / \mathrm{CH}_{3} \mathrm{CN}(0.1 \% \mathrm{TFA})$ 95:5 $\rightarrow 5: 95(0 \rightarrow 5 \mathrm{~min})] .{ }^{1} \mathbf{H}$ NMR $\left(300 \mathrm{MHz}, \mathrm{D}_{2} \mathrm{O}, \delta\right): 7.77(\mathrm{t}, J=5.3 \mathrm{~Hz}, 1 \mathrm{H}), 7.17(\mathrm{t}, J=3.9 \mathrm{~Hz}, 1 \mathrm{H}), 4.93(\mathrm{~s}$, 2H), $4.59(\mathrm{~s}, 4 \mathrm{H}), 4.45-4.22(\mathrm{~m}, 17 \mathrm{H}), 4.07-3.64(\mathrm{~m}, 12 \mathrm{H}), 3.33-3.16(\mathrm{~m}, 16 \mathrm{H}), 2.07(\mathrm{~s}, 3 \mathrm{H}), 1.98-1.32(\mathrm{~m}, 51 \mathrm{H})$, 1.03-0.82 (m, 30H). MS (ESI, $\left.\mathrm{H}_{2} \mathrm{O}\right): 1300\left(19,[\mathrm{M}+2 \mathrm{H}+2 \mathrm{TFA}]^{2+}\right), 1243\left(21,[\mathrm{M}+2 \mathrm{H}+\mathrm{TFA}]^{2+}\right), 1187(23$, $\left.[\mathrm{M}+2 \mathrm{H}]^{2+}\right), 867\left(42,[\mathrm{M}+3 \mathrm{H}+2 \mathrm{TFA}]^{3+}\right), 827\left(67,[\mathrm{M}+3 \mathrm{H}+\mathrm{TFA}]^{3+}\right), 791\left(100,[\mathrm{M}+3 \mathrm{H}]^{3+}\right), 593\left(38,[\mathrm{M}+4 \mathrm{H}]^{4+}\right)$. HRMS (ESI): Calcd for $\mathrm{C}_{100} \mathrm{H}_{188} \mathrm{~N}_{36} \mathrm{O}_{30}$ : 1186.7139; found: $1186.7141\left([\mathrm{M}+2 \mathrm{H}]^{2+}\right)$.

\section{Synthesis of $\operatorname{TmP}(\operatorname{Man})_{2}$}

Following the general protocol of the SPPS for synthesizing a TAMRA labelled peptide with two mannoses, $\operatorname{TmP}(\mathrm{Man})_{2}$ was obtained after RP-HPLC purification [Phenomenex Luna C18(2) 100A column, $\mathrm{H}_{2} \mathrm{O}(0.1 \%$ TFA)/ $\mathrm{CH}_{3} \mathrm{CN}(0.1 \%$ TFA) 95:5 $\rightarrow 5: 95(0 \rightarrow 5 \mathrm{~min}), 95: 5 \rightarrow 5: 95(5 \rightarrow 35 \mathrm{~min})]$ with an overall yield of $6 \%$ and $100 \%$ purity. $R_{\mathrm{t}} 4.1 \mathrm{~min}$ (Fig. S17) [RP-HPLC Agilent SB-C18 column, $\mathrm{H}_{2} \mathrm{O}\left(0.1 \%\right.$ TFA)/ $\mathrm{CH}_{3} \mathrm{CN}(0.1 \%$ TFA) 95:5 $\rightarrow 5: 95(0 \rightarrow 5 \mathrm{~min})] .{ }^{1} \mathbf{H}$ NMR $\left(500 \mathrm{MHz}, \mathrm{D}_{2} \mathrm{O}, \delta\right): 8.21(\mathrm{~s}, 1 \mathrm{H}), 7.92(\mathrm{~d}, J=8.1 \mathrm{~Hz}, 1 \mathrm{H}), 7.58(\mathrm{~m}, 1 \mathrm{H}), 7.36$ $(\mathrm{d}, J=8.1 \mathrm{~Hz}, 1 \mathrm{H}), 7.11(\mathrm{t}, J=9.9 \mathrm{~Hz}, 2 \mathrm{H}), 6.97(\mathrm{~m}, 1 \mathrm{H}), 6.83(\mathrm{~d}, J=9.6 \mathrm{~Hz}, 2 \mathrm{H}), 6.75(\mathrm{~s}, 2 \mathrm{H}), 4.80-4.73(\mathrm{~m}$, 2H), $4.68(\mathrm{~s}, 4 \mathrm{H}), 4.40(\mathrm{~d}, J=24.1 \mathrm{~Hz}, 4 \mathrm{H}), 4.28-3.96(\mathrm{~m}, 13 \mathrm{H}), 3.87-3.24(\mathrm{~m}, 12 \mathrm{H}), 3.13(\mathrm{~s}, 12 \mathrm{H}), 3.10-2.95$ (m, 16H), 2.91-2.80 (m, 2H), $2.25(\mathrm{t}, J=7.1 \mathrm{~Hz}, 2 \mathrm{H}), 1.79-1.11(\mathrm{~m}, 57 \mathrm{H}), 0.87-0.67(\mathrm{~m}, 30 \mathrm{H})$. MS (ESI, $\left.\mathrm{H}_{2} \mathrm{O}\right): 1657$ $\left(7,[\mathrm{M}+2 \mathrm{H}+4 \mathrm{TFA}]^{2+}\right), 1599\left(17,[\mathrm{M}+2 \mathrm{H}+3 \mathrm{TFA}]^{2+}\right), 1542\left(15,[\mathrm{M}+2 \mathrm{H}+\mathrm{TFA}]^{2+}\right), 1027\left(100,[\mathrm{M}+3 \mathrm{H}+2 \mathrm{TFA}]^{3+}\right)$, $989\left(99,[\mathrm{M}+3 \mathrm{H}+\mathrm{TFA}]^{3+}\right), 743\left(62,[\mathrm{M}+4 \mathrm{H}+\mathrm{TFA}]^{4+}\right), 716\left(53,[\mathrm{M}+4 \mathrm{H}]^{4+}\right) . \quad$ HRMS (ESI): Calcd for $\mathrm{C}_{129} \mathrm{H}_{217} \mathrm{~N}_{39} \mathrm{O}_{34}$ : 1428.3209 ; found: $1428.3220\left([\mathrm{M}+2 \mathrm{H}]^{2+}\right)$. 
Following the general protocol of the SPPS for synthesizing an acetylated peptide with one mannose, and using Alloc protected Lysine, AcP(Alloc)(Man) was obtained after RP-HPLC purification [Phenomenex Luna C18(2) $100 \mathrm{~A}$ column, $\mathrm{H}_{2} \mathrm{O}(0.1 \% \mathrm{TFA}) / \mathrm{CH}_{3} \mathrm{CN}(0.1 \% \mathrm{TFA})$ 95:5 $\left.\rightarrow 5: 95(0 \rightarrow 5 \mathrm{~min}), 95: 5 \rightarrow 5: 95(5 \rightarrow 35 \mathrm{~min})\right]$ with an overall yield of $15 \%$ and $100 \%$ purity. $R_{\mathrm{t}} 4.1$ min (Fig. S18) [RP-HPLC Agilent SB-C18 column, $\mathrm{H}_{2} \mathrm{O}(0.1 \%$ TFA)/ $\mathrm{CH}_{3} \mathrm{CN}(0.1 \%$ TFA) 95:5 $\rightarrow 5: 95(0 \rightarrow 5 \mathrm{~min})] .{ }^{1} \mathbf{H}$ NMR $\left(300 \mathrm{MHz}, \mathrm{D}_{2} \mathrm{O}, \delta\right): 7.62(\mathrm{t}, J=5.3 \mathrm{~Hz}, 1 \mathrm{H}), 7.02$ $(\mathrm{t}, J=3.7 \mathrm{~Hz}, 1 \mathrm{H}), 5.90-5.73(\mathrm{~m}, 1 \mathrm{H}), 5.23-5.06(\mathrm{~m}, 2 \mathrm{H}), 4.78(\mathrm{~s}, 1 \mathrm{H}), 4.48-4.39(\mathrm{~m}, 5 \mathrm{H}), 4.31-4.04(\mathrm{~m}, 15 \mathrm{H})$, 3.89-3.46 (m, 6H), 3.15-2.95 (m, 16H), $1.92(\mathrm{~s}, 3 \mathrm{H}), 1.78-1.12(\mathrm{~m}, 51 \mathrm{H})$, 0.87-0.70 (m, 30H). MS (ESI, $\left.\mathrm{H}_{2} \mathrm{O}\right)$ : $1260\left(18, \quad[\mathrm{M}+2 \mathrm{H}+3 \mathrm{TFA}]^{2+}\right), \quad 1203 \quad\left(27, \quad[\mathrm{M}+2 \mathrm{H}+2 \mathrm{TFA}]^{2+}\right), \quad 1147 \quad\left(20, \quad[\mathrm{M}+2 \mathrm{H}+\mathrm{TFA}]^{2+}\right), \quad 803 \quad(38$, $\left.[\mathrm{M}+3 \mathrm{H}+2 \mathrm{TFA}]^{3+}\right), 763\left(100,[\mathrm{M}+3 \mathrm{H}+\mathrm{TFA}]^{3+}\right), 727\left(42,[\mathrm{M}+3 \mathrm{H}]^{3+}\right), 574\left(10,[\mathrm{M}+4 \mathrm{H}+\mathrm{TFA}]^{4+}\right), 547(27$, $\left.[\mathrm{M}+4 \mathrm{H}]^{4+}\right)$. HRMS (ESI): Calcd for $\mathrm{C}_{94} \mathrm{H}_{175} \mathrm{~N}_{35} \mathrm{O}_{24}: 1090.6868$; found: $1090.6871\left([\mathrm{M}+2 \mathrm{H}]^{2+}\right)$.

Synthesis of TmP(Alloc)(Man)

Following the general protocol of the SPPS for synthesizing a TAMRA labelled peptide with one mannose, and using Alloc protected Lysine, TmP(Alloc)(Man) was obtained after RP-HPLC purification [Phenomenex Luna C18(2) 100A column, $\mathrm{H}_{2} \mathrm{O}(0.1 \% \mathrm{TFA}) / \mathrm{CH}_{3} \mathrm{CN}(0.1 \%$ TFA) $95: 5 \rightarrow 5: 95$ (0 $\rightarrow 5 \mathrm{~min}), 95: 5 \rightarrow 5: 95$ (5 $\left.\left.\rightarrow 35 \mathrm{~min}\right)\right]$ with an overall yield of $10 \%$ and $98.4 \%$ purity. $R_{\mathrm{t}} 4.3$ min (Fig. S19) [RP-HPLC Agilent SB-C18 column, $\mathrm{H}_{2} \mathrm{O}$ $(0.1 \% \mathrm{TFA}) / \mathrm{CH}_{3} \mathrm{CN}(0.1 \% \mathrm{TFA})$ 95:5 $\left.\rightarrow 5: 95(0 \rightarrow 5 \mathrm{~min})\right] .{ }^{1} \mathbf{H}$ NMR $\left(300 \mathrm{MHz}, \mathrm{D}_{2} \mathrm{O}, \delta\right): 8.24(\mathrm{~s}, 1 \mathrm{H}), 8.08$ $7.87(\mathrm{~m}, 2 \mathrm{H}), 7.55(\mathrm{~m}, 1 \mathrm{H}), 7.03(\mathrm{~s}, 2 \mathrm{H}), 6.88-6.61(\mathrm{~m}, 3 \mathrm{H}), 5.71(\mathrm{~m}, 2 \mathrm{H}), 5.07(\mathrm{~m}, 3 \mathrm{H}), 4.52-4.30(\mathrm{~m}, 4 \mathrm{H}), 4.29$ $(\mathrm{s}, 2 \mathrm{H}), 4.26-3.92(\mathrm{~m}, 13 \mathrm{H}), 3.86-3.44(\mathrm{~m}, 6 \mathrm{H}), 3.30(\mathrm{~m}, 2 \mathrm{H}), 3.09(\mathrm{~s}, 12 \mathrm{H}), 3.08(\mathrm{~s}, 16 \mathrm{H}), 2.22(\mathrm{~m}, 2 \mathrm{H}), 1.96-$ $1.12(\mathrm{~m}, 57 \mathrm{H}), 0.95-0.59(\mathrm{~m}, 30 \mathrm{H}) . \mathbf{M S}\left(\mathrm{ESI}, \mathrm{H}_{2} \mathrm{O}\right): 965\left(43,[\mathrm{M}+3 \mathrm{H}+2 \mathrm{TFA}]^{3+}\right), 927\left(100,[\mathrm{M}+3 \mathrm{H}+\mathrm{TFA}]^{3+}\right), 668$ $\left(40,[\mathrm{M}+4 \mathrm{H}]^{4+}\right), 533\left(10,[\mathrm{M}+5 \mathrm{H}]^{5+}\right)$. HRMS (ESI): Calcd for $\mathrm{C}_{123} \mathrm{H}_{204} \mathrm{~N}_{38} \mathrm{O}_{28}$ : 888.5326; found: 888.5330 $\left([\mathrm{M}+3 \mathrm{H}]^{3+}\right)$.

Synthesis of AcP(Acetone) $)_{2}$

Following the general protocol of the SPPS for synthesizing an acetylated peptide capped with acetone, $\mathrm{AcP}(\text { Acetone })_{2}$ was obtained after RP-HPLC purification [Phenomenex Luna C18(2) 100A column, $\mathrm{H}_{2} \mathrm{O}(0.1 \%$ TFA)/ $\mathrm{CH}_{3} \mathrm{CN}(0.1 \%$ TFA) 95:5 $\rightarrow 5: 95(0 \rightarrow 5 \mathrm{~min}), 95: 5 \rightarrow 5: 95(5 \rightarrow 35 \mathrm{~min})]$ with an overall yield of $4 \%$ and $100 \%$ purity. $R_{\mathrm{t}} 4.3 \mathrm{~min}$ (Fig. S20) [RP-HPLC Agilent SB-C18 column, $\mathrm{H}_{2} \mathrm{O}(0.1 \% \mathrm{TFA}) / \mathrm{CH}_{3} \mathrm{CN}(0.1 \%$ TFA) 95:5 $\rightarrow 5: 95(0 \rightarrow 5 \mathrm{~min})] .{ }^{1} \mathbf{H}$ NMR $\left(300 \mathrm{MHz}, \mathrm{D}_{2} \mathrm{O}, \delta\right): 4.36(\mathrm{~s}, 4 \mathrm{H}), 4.27-4.05(\mathrm{~m}, 13 \mathrm{H}), 3.20-3.00(\mathrm{~m}, 16 \mathrm{H})$, $1.92(\mathrm{~s}, 3 \mathrm{H}), 1.83(\mathrm{~s}, 6 \mathrm{H}), 1.76(\mathrm{~s}, 6 \mathrm{H}), 1.71-1.17(\mathrm{~m}, 51 \mathrm{H}), 0.85-0.69(\mathrm{~m}, 30 \mathrm{H}) ;$ MS (ESI, $\left.\mathrm{H}_{2} \mathrm{O}\right): 1193(30$, $\left.[\mathrm{M}+2 \mathrm{H}+3 \mathrm{TFA}]^{2+}\right), 1133\left(39,[\mathrm{M}+2 \mathrm{H}+2 \mathrm{TFA}]^{2+}\right), 1077\left(23,[\mathrm{M}+2 \mathrm{H}+\mathrm{TFA}]^{2+}\right), 757\left(30,[\mathrm{M}+3 \mathrm{H}+3 \mathrm{TFA}]^{3+}\right), 720$ $\left(100,[\mathrm{M}+3 \mathrm{H}+\mathrm{TFA}]^{3+}\right), 680\left(61,[\mathrm{M}+3 \mathrm{H}]^{3+}\right), 513\left(30,[\mathrm{M}+4 \mathrm{H}]^{4+}\right)$. HRMS (ESI): Calcd for $\mathrm{C}_{90} \mathrm{H}_{172} \mathrm{~N}_{36} \mathrm{O}_{18}$ : 1022.6820; found: $1022.6820\left([\mathrm{M}+2 \mathrm{H}]^{2+}\right)$. 
Following the general protocol of the SPPS for synthesizing a TAMRA labelled peptide capped with acetone, $\operatorname{TmP}(\text { Acetone })_{2}$ was obtained after RP-HPLC purification [Phenomenex Luna C18(2) $100 \mathrm{~A}$ column, $\mathrm{H}_{2} \mathrm{O}(0.1 \%$ TFA $) / \mathrm{CH}_{3} \mathrm{CN}(0.1 \%$ TFA) 95:5 $\rightarrow 5: 95(0 \rightarrow 5 \mathrm{~min}), 95: 5 \rightarrow 5: 95(5 \rightarrow 35 \mathrm{~min})]$ with an overall yield of $12 \%$ and 99.9\% purity. $R_{\mathrm{t}} 4.4$ min (Fig. S21) [RP-HPLC Agilent SB-C18 column, $\mathrm{H}_{2} \mathrm{O}(0.1 \% \mathrm{TFA}) / \mathrm{CH}_{3} \mathrm{CN}(0.1 \% \mathrm{TFA})$ 95:5 $\rightarrow 5: 95(0 \rightarrow 5 \mathrm{~min})] .{ }^{1} \mathbf{H}$ NMR $\left(300 \mathrm{MHz}, \mathrm{D}_{2} \mathrm{O}, \delta\right): 8.07-7.89(\mathrm{~m}, 2 \mathrm{H}), 7.55(\mathrm{~s}, 1 \mathrm{H}), 7.03(\mathrm{~d}, J=9.2 \mathrm{~Hz}$, 2H), 6.89-6.69 (m, 4H), 4.34 (d, J=7.9 Hz, 4H), 4.27-3.93 (m, 13H), 3.40-3.22 (m, 2H), 3.10 (s, 12H), 3.07-2.98 (m, 16H), 2.31-2.11 (m, 2H), 1.89-1.63 (m, 12H), 1.60-1.10 (m, 57H), 0.88-0.64 (m, 30H). MS (ESI, H $\left.\mathrm{H}_{2} \mathrm{O}\right): 1492$ $\left(8,[\mathrm{M}+2 \mathrm{H}+4 \mathrm{TFA}]^{2+}\right), 1434\left(10,[\mathrm{M}+2 \mathrm{H}+3 \mathrm{TFA}]^{2+}\right), 1376\left(8,[\mathrm{M}+2 \mathrm{H}+2 \mathrm{TFA}]^{2+}\right), 918\left(100,[\mathrm{M}+3 \mathrm{H}+2 \mathrm{TFA}]^{3+}\right)$, $881\left(100,[\mathrm{M}+3 \mathrm{H}+\mathrm{TFA}]^{3+}\right), 690\left(18,[\mathrm{M}+4 \mathrm{H}+2 \mathrm{TFA}]^{4+}\right), 662\left(40,[\mathrm{M}+4 \mathrm{H}+\mathrm{TFA}]^{4+}\right), 632\left(18,[\mathrm{M}+4 \mathrm{H}]^{4+}\right)$. HRMS (ESI): Calcd for $\mathrm{C}_{119} \mathrm{H}_{201} \mathrm{~N}_{39} \mathrm{O}_{22}$ : 1264.2902; found: $1264.2899\left([\mathrm{M}+2 \mathrm{H}]^{2+}\right)$.

Synthesis of $\operatorname{AcArg}_{2}(\operatorname{Man})_{2}$

Following the general protocol of the SPPS for synthesizing an acetylated tetrapeptide with two mannoses, $\operatorname{AcArg}_{2}(\mathrm{Man})_{2}$ was obtained after RP- HPLC purification [Phenomenex Luna C18(2) $100 \mathrm{~A}$ column, $\mathrm{H}_{2} \mathrm{O}(0.1 \%$ TFA) $/ \mathrm{CH}_{3} \mathrm{CN}(0.1 \%$ TFA) $95: 5 \rightarrow 5: 95(0 \rightarrow 5 \mathrm{~min}), 95: 5 \rightarrow 5: 95(5 \rightarrow 35 \mathrm{~min})]$ with an overall yield of $15 \%$ and $100 \%$ purity. $R_{\mathrm{t}} 3.1 \mathrm{~min}$ (Fig. S22) [RP-HPLC Agilent SB-C18 column, $\mathrm{H}_{2} \mathrm{O}(0.1 \% \mathrm{TFA}) / \mathrm{CH}_{3} \mathrm{CN}(0.1 \% \mathrm{TFA})$ 95:5 $\rightarrow 5: 95(0 \rightarrow 5 \mathrm{~min})] .{ }^{1} \mathrm{H}$ NMR $\left(300 \mathrm{MHz}, \mathrm{D}_{2} \mathrm{O}, \delta\right): 7.62(\mathrm{t}, J=5.3 \mathrm{~Hz}, 1 \mathrm{H}), 7.02(\mathrm{t}, J=3.9 \mathrm{~Hz}, 1 \mathrm{H}), 4.78(\mathrm{~s}$, 2H), 4.44 (s, 4H), 4.25-4.07 (m, 8H), 3.90-3.47 (m, 12H), 3.20-2.98 (m, 8H), 1.91 (s, 3H), 1.83-1.13 (m, 20H). MS (ESI, $\left.\mathrm{H}_{2} \mathrm{O}\right): 1183\left(17,[\mathrm{M}+\mathrm{H}]^{+}\right), 590\left(100,[\mathrm{M}+2 \mathrm{H}]^{2+}\right)$. HRMS (ESI): Calcd for $\mathrm{C}_{46} \mathrm{H}_{84} \mathrm{~N}_{15} \mathrm{O}_{21}: 1182.5963$; found: $1182.5961\left([\mathrm{M}+\mathrm{H}]^{+}\right)$.

Synthesis of $\operatorname{TmArg}_{2}(\mathrm{Man})_{2}$

Following the general protocol of the SPPS for synthesizing a TAMRA labelled tetrapeptide with two mannoses, $\operatorname{TmArg}_{2}(\mathrm{Man})_{2}$ was obtained after RP-HPLC purification [Phenomenex Luna C18(2) $100 \mathrm{~A}$ column, $\mathrm{H}_{2} \mathrm{O}(0.1 \%$ TFA)/ $\mathrm{CH}_{3} \mathrm{CN}(0.1 \%$ TFA) 95:5 $\rightarrow 5: 95(0 \rightarrow 5 \mathrm{~min}), 95: 5 \rightarrow 5: 95(5 \rightarrow 35 \mathrm{~min})]$ with an overall yield of $26 \%$ and $100 \%$ purity. $R_{\mathrm{t}} 3.8 \mathrm{~min}$ (Fig. S23) [RP-HPLC Agilent SB-C18 column, $\mathrm{H}_{2} \mathrm{O}(0.1 \% \mathrm{TFA}) / \mathrm{CH}_{3} \mathrm{CN}(0.1 \% \mathrm{TFA})$ 95:5 $\rightarrow 5: 95(0 \rightarrow 5 \mathrm{~min})] .{ }^{1} \mathbf{H}$ NMR $\left(300 \mathrm{MHz}, \mathrm{D}_{2} \mathrm{O}, \delta\right): 8.35(\mathrm{~d}, J=14.1 \mathrm{~Hz}, 1 \mathrm{H}), 7.99(\mathrm{t}, J=5.5 \mathrm{~Hz}, 1 \mathrm{H}), 7.56(\mathrm{t}$, $J=10.4 \mathrm{~Hz}, 1 \mathrm{H}), 7.43(\mathrm{~d}, J=7.8 \mathrm{~Hz}, 1 \mathrm{H}), 7.11-6.98(\mathrm{~m}, 2 \mathrm{H}), 6.95(\mathrm{~s}, 1 \mathrm{H}), 6.80(\mathrm{~d}, J=9.5 \mathrm{~Hz}, 2 \mathrm{H}), 6.64(\mathrm{~d}, J=$ $7.0 \mathrm{~Hz}, 2 \mathrm{H}), 4.73(\mathrm{~s}, 2 \mathrm{H}), 4.38(\mathrm{~s}, 4 \mathrm{H}), 4.22-3.99(\mathrm{~m}, 4 \mathrm{H}), 3.85-3.33(\mathrm{~m}, 12 \mathrm{H}), 3.10(\mathrm{~s}, 12 \mathrm{H}), 3.08-2.98(\mathrm{~m}, 12 \mathrm{H})$, $2.86(\mathrm{t}, J=7.5 \mathrm{~Hz}, 2 \mathrm{H}), 2.24(\mathrm{t}, J=7.0 \mathrm{~Hz}, 2 \mathrm{H}), 1.81-1.12(\mathrm{~m}, 26 \mathrm{H}) . \mathbf{M S}\left(\mathrm{ESI}, \mathrm{H}_{2} \mathrm{O}\right): 834\left(100,[\mathrm{M}+2 \mathrm{H}]^{2+}\right), 556$ $\left(95,[\mathrm{M}+3 \mathrm{H}]^{3+}\right)$. HRMS (ESI): Calcd for $\mathrm{C}_{75} \mathrm{H}_{114} \mathrm{~N}_{18} \mathrm{O}_{25}: 833.4088$; found: $833.4096\left([\mathrm{M}+2 \mathrm{H}]^{2+}\right)$.

Synthesis of $\operatorname{TmArg}_{6} \mathrm{Gly}_{5}(\mathrm{Man})_{2}$

Following the general protocol of the SPPS for synthesizing a TAMRA labelled peptide with two mannoses, $\mathrm{TmArg}_{6} \mathrm{Gly}_{5}(\mathrm{Man})_{2}$ was obtained after RP-HPLC purification [Phenomenex Luna C18(2) 100A column, $\mathrm{H}_{2} \mathrm{O}$ 
$\left.(0.1 \% \mathrm{TFA}) / \mathrm{CH}_{3} \mathrm{CN}(0.1 \% \mathrm{TFA}) 95: 5 \rightarrow 5: 95(0 \rightarrow 5 \mathrm{~min}), 95: 5 \rightarrow 5: 95(5 \rightarrow 35 \mathrm{~min})\right]$ with an overall yield of $9 \%$ and $100 \%$ purity. $R_{\mathrm{t}} 3.4 \mathrm{~min}$ (Fig. S24) [RP-HPLC Agilent SB-C18 column, $\mathrm{H}_{2} \mathrm{O}(0.1 \% \mathrm{TFA}) / \mathrm{CH}_{3} \mathrm{CN}(0.1 \%$ TFA) 95:5 $\rightarrow 5: 95(0 \rightarrow 5 \mathrm{~min})] .{ }^{1} \mathbf{H}$ NMR $\left(500 \mathrm{MHz}, \mathrm{D}_{2} \mathrm{O}, \delta\right): 8.42(\mathrm{~s}, 1 \mathrm{H}), 8.02(\mathrm{~s}, 1 \mathrm{H}), 7.66-7.49(\mathrm{~m}, 1 \mathrm{H}), 7.41$ (s, 1H), 7.09-6.88 (m, 3H), $6.71(\mathrm{~s}, 2 \mathrm{H}), 6.29(\mathrm{~s}, 2 \mathrm{H}), 4.77(\mathrm{~s}, 2 \mathrm{H}), 4.74(\mathrm{~s}, 4 \mathrm{H}), 4.46-4.30(\mathrm{~m}, 4 \mathrm{H}), 4.27-4.04(\mathrm{~m}$, $10 \mathrm{H}), 3.98-3.73(\mathrm{~m}, 16 \mathrm{H}), 3.75-3.45(\mathrm{~m}, 12 \mathrm{H}), 3.37$ (d, J=5.3 Hz, 2H), 3.17-3.01 (m, 12H), $2.98(\mathrm{~s}, 8 \mathrm{H}), 2.24(\mathrm{~s}$, 2H), 1.85-1.10 (m, 42H). MS (ESI, $\left.\mathrm{H}_{2} \mathrm{O}\right): 1402\left(7,[\mathrm{M}+2 \mathrm{H}+2 \mathrm{TFA}]^{2+}\right), 973\left(42,[\mathrm{M}+3 \mathrm{H}+3 \mathrm{TFA}]^{3+}\right), 936(100$, $\left.[\mathrm{M}+3 \mathrm{H}+2 \mathrm{TFA}]^{3+}\right), 898\left(65,[\mathrm{M}+3 \mathrm{H}+\mathrm{TFA}]^{3+}\right), 702\left(60,[\mathrm{M}+4 \mathrm{H}+2 \mathrm{TFA}]^{4+}\right), 674\left(95,[\mathrm{M}+4 \mathrm{H}+\mathrm{TFA}]^{4+}\right), 645(35$, $\left.[\mathrm{M}+4 \mathrm{H}]^{4+}\right), 516\left(45,[\mathrm{M}+5 \mathrm{H}]^{5+}\right)$. HRMS (ESI): Calcd for $\mathrm{C}_{109} \mathrm{H}_{177} \mathrm{~N}_{39} \mathrm{O}_{34}$ : 1288.1651; found: 1288.1655 $\left([\mathrm{M}+2 \mathrm{H}]^{2+}\right)$.

Synthesis of $\operatorname{TmArg}_{6}(\text { Man })_{2}$

Following the general protocol of the SPPS for synthesizing a TAMRA labelled peptide with two mannoses, $\operatorname{TmArg}_{6}(\mathrm{Man})_{2}$ was obtained after RP-HPLC purification [Phenomenex Luna C18(2) 100A column, $\mathrm{H}_{2} \mathrm{O}(0.1 \%$ TFA) $/ \mathrm{CH}_{3} \mathrm{CN}(0.1 \%$ TFA) 95:5 $\rightarrow 5: 95(0 \rightarrow 5 \mathrm{~min}), 95: 5 \rightarrow 5: 95(5 \rightarrow 35 \mathrm{~min})]$ with an overall yield of $9 \%$ and $100 \%$ purity. $R_{\mathrm{t}} 3.4 \mathrm{~min}$ (Fig. S25) [RP-HPLC Agilent SB-C18 column, $\mathrm{H}_{2} \mathrm{O}(0.1 \% \mathrm{TFA}) / \mathrm{CH}_{3} \mathrm{CN}(0.1 \% \mathrm{TFA})$ 95:5 $\rightarrow 5: 95(0 \rightarrow 5 \mathrm{~min})] .{ }^{1} \mathbf{H}$ NMR $\left(300 \mathrm{MHz}, \mathrm{D}_{2} \mathrm{O}, \delta\right): 8.41(\mathrm{~s}, 1 \mathrm{H}), 7.99(\mathrm{~d}, J=8.5 \mathrm{~Hz}, 1 \mathrm{H}), 7.57-7.29(\mathrm{~m}, 2 \mathrm{H})$, 7.00-6.85 (m, 3H), $6.68(\mathrm{~d}, J=9.3 \mathrm{~Hz}, 2 \mathrm{H}), 6.33(\mathrm{~s}, 2 \mathrm{H}), 4.84-4.66(\mathrm{~m}, 2 \mathrm{H}), 4.70-4.65(\mathrm{~m}, 4 \mathrm{H}), 4.32(\mathrm{~d}, J=15.0$ $\mathrm{Hz}, 4 \mathrm{H}), 4.17-3.91(\mathrm{~m}, 8 \mathrm{H}), 3.88-3.37(\mathrm{~m}, 12 \mathrm{H}), 3.34-3.24(\mathrm{~m}, 2 \mathrm{H}), 2.98(\mathrm{~s}, 12 \mathrm{H}), 2.96(\mathrm{~s}, 16 \mathrm{H}), 2.23-2.08$ (m, 2H), 1.77-1.03 (m, 42H). MS (ESI, $\left.\mathrm{H}_{2} \mathrm{O}\right): 840\left(90,[\mathrm{M}+3 \mathrm{H}+2 \mathrm{TFA}]^{3+}\right), 803\left(100,[\mathrm{M}+3 \mathrm{H}+\mathrm{TFA}]^{3+}\right), 765(30$, $\left.[\mathrm{M}+3 \mathrm{H}]^{3+}\right), 629\left(30,[\mathrm{M}+4 \mathrm{H}+2 \mathrm{TFA}]^{4+}\right), 602\left(25,[\mathrm{M}+4 \mathrm{H}+\mathrm{TFA}]^{4+}\right)$. HRMS (ESI): Calcd for $\mathrm{C}_{99} \mathrm{H}_{162} \mathrm{~N}_{34} \mathrm{O}_{29}$ : 1145.6119; found: $1145.6118\left([\mathrm{M}+2 \mathrm{H}]^{2+}\right)$.

Synthesis of DexP(Man $)_{2}$

Following the general protocol of the SPPS for synthesizing an Dex labelled peptide with two mannoses, DexP(Man $)_{2}$ was obtained after RP-HPLC purification [Phenomenex Luna C18(2) 100A column, $\mathrm{H}_{2} \mathrm{O}(0.1 \%$ TFA)/ $\mathrm{CH}_{3} \mathrm{CN}(0.1 \%$ TFA) $95: 5 \rightarrow 5: 95(0 \rightarrow 5 \mathrm{~min}), 95: 5 \rightarrow 5: 95(5 \rightarrow 35 \mathrm{~min})]$ with an overall yield of $5 \%$ and 99.6\% purity. $R_{\mathrm{t}} 4.2$ min (Fig. S26) [RP-HPLC Agilent SB-C18 column, $\mathrm{H}_{2} \mathrm{O}(0.1 \% \mathrm{TFA}) / \mathrm{CH}_{3} \mathrm{CN}(0.1 \% \mathrm{TFA})$ 95:5 $\rightarrow 5: 95(0 \rightarrow 5 \mathrm{~min})] .{ }^{1} \mathbf{H}$ NMR $\left(300 \mathrm{MHz}, \mathrm{D}_{2} \mathrm{O}, \delta\right): 7.62(\mathrm{~s}, 1 \mathrm{H}), 7.38(\mathrm{~d}, J=10.4 \mathrm{~Hz}, 1 \mathrm{H}), 7.00(\mathrm{~s}, 1 \mathrm{H}), 6.27$ $(\mathrm{d}, J=9.9 \mathrm{~Hz}, 1 \mathrm{H}), 6.07(\mathrm{~s}, 1 \mathrm{H}), 4.77(\mathrm{~s}, 2 \mathrm{H}), 4.43(\mathrm{~s}, 8 \mathrm{H}), 4.13(\mathrm{~m}, 13 \mathrm{H}), 3.87-3.44(\mathrm{~m}, 12 \mathrm{H}), 3.23(\mathrm{~s}, 2 \mathrm{H}), 3.15-$ $2.90(\mathrm{~m}, 16 \mathrm{H}), 2.84(\mathrm{~m}, 2 \mathrm{H}), 2.26(\mathrm{~m}, 2 \mathrm{H}), 2.03-1.11(\mathrm{~m}, 70 \mathrm{H}), 0.93-0.62(\mathrm{~m}, 36 \mathrm{H})$. MS (ESI, $\left.\mathrm{H}_{2} \mathrm{O}\right): 1573(18$, $\left.[\mathrm{M}+2 \mathrm{H}+3 \mathrm{TFA}]^{2+}\right), 1517\left(20,[\mathrm{M}+2 \mathrm{H}+2 \mathrm{TFA}]^{2+}\right), 1049\left(22,[\mathrm{M}+3 \mathrm{H}+3 \mathrm{TFA}]^{3+}\right), 1011\left(90[\mathrm{M}+3 \mathrm{H}+2 \mathrm{TFA}]^{3+}\right), 974$ $\left(100,[\mathrm{M}+3 \mathrm{H}+\mathrm{TFA}]^{3+}\right), 938\left(50,[\mathrm{M}+3 \mathrm{H}]^{3+}\right)$. HRMS (ESI): Calcd for $\mathrm{C}_{125} \mathrm{H}_{222} \mathrm{FN}_{37} \mathrm{O}_{34}: 1402.3371$; found: $1402.3376\left([\mathrm{M}+2 \mathrm{H}]^{2+}\right)$.

Synthesis of CFArg 8

For the preparation of the control peptide $\mathrm{CFArg}_{8}$, the carboxyfluorescein was coupled in the amino group of a lysine Mtt localized at the end of the peptide sequence. Therefore, following the general protocol of the SPPS for 
growing the peptide, the Mtt protecting group was selectively removed by mechanically stirring the resin with a mixture of DCM/HFIP/TFE/TIS (6.5:2:1:0.5, $2 \times 1 \mathrm{~mL}$ per $70 \mathrm{mg}$ of resin) for $2 \mathrm{~h}$. Finally, the mixture was filtered and the resin was washed with DCM $(2 \times 2 \mathrm{~mL}, 2 \mathrm{~min})$ and DMF (2 mL, $20 \mathrm{~min})$. Then, a solution of $5(6)$-carboxyfluorescein (2 equiv) and $N$-HBTU (2 equiv) in DMF (1 mL) was added to the vessel followed by the drop wise addition of DIEA (4 equiv). The resulting mixture was shaken by bubbling Ar for 30 min and finally the filtered resin was washed with DMF (3 x $2 \mathrm{ml}, 2 \mathrm{~min})$ and DCM (3 x $2 \mathrm{ml}, 2 \mathrm{~min})$ (Fig. S10).

$\mathrm{CFArg}_{8}$ was obtained after RP-HPLC purification [Phenomenex Luna C18(2) 100A column, $\mathrm{H}_{2} \mathrm{O}$ (0.1\% TFA)/ $\mathrm{CH}_{3} \mathrm{CN}(0.1 \%$ TFA) 95:5 $\rightarrow$ 5:95 $(0 \rightarrow 5 \mathrm{~min}), 95: 5 \rightarrow 5: 95(5 \rightarrow 35 \mathrm{~min})]$ with an overall yield of $11 \%$ and $100 \%$ purity. $R_{\mathrm{t}} 3.2 \mathrm{~min}$ (Fig. S27) [RP-HPLC Agilent SB-C18 column, $\mathrm{H}_{2} \mathrm{O}(0.1 \% \mathrm{TFA}) / \mathrm{CH}_{3} \mathrm{CN}(0.1 \% \mathrm{TFA})$ 95:5 $\rightarrow 5: 95(0 \rightarrow 5 \mathrm{~min})] .{ }^{1} \mathbf{H}$ NMR $\left(500 \mathrm{MHz}, \mathrm{D}_{2} \mathrm{O}, \delta\right): 8.16(\mathrm{~d}, J=1.8 \mathrm{~Hz}, 1 \mathrm{H}), 7.93(\mathrm{t}, J=7.9 \mathrm{~Hz}, 1 \mathrm{H}), 7.58(\mathrm{~s}$, $1 \mathrm{H}), 7.36(\mathrm{~d}, J=7.9 \mathrm{~Hz}, 1 \mathrm{H}), 7.17-7.06(\mathrm{~m}, 2 \mathrm{H}), 6.86-6.77(\mathrm{~m}, 1 \mathrm{H}), 6.72(\mathrm{td}, J=9.3$ and $1.8 \mathrm{~Hz}, 1 \mathrm{H}), 6.60(\mathrm{dd}, J$ $=9.2$ and $2.4 \mathrm{~Hz}, 1 \mathrm{H}), 4.24-3.86(\mathrm{~m}, 9 \mathrm{H}), 3.32(\mathrm{~m}, 2 \mathrm{H}), 3.12-2.87(\mathrm{~m}, 16 \mathrm{H}), 1.88(\mathrm{~d}, J=10.2 \mathrm{~Hz}, 3 \mathrm{H}), 1.76-1.16$ $(\mathrm{m}, 38 \mathrm{H}) . \mathbf{M S}\left(\mathrm{ESI}, \mathrm{H}_{2} \mathrm{O}\right): 675\left(50,[\mathrm{M}+3 \mathrm{H}+2 \mathrm{TFA}]^{3+}\right), 638\left(100,[\mathrm{M}+3 \mathrm{H}+\mathrm{TFA}]^{3+}\right), 599\left(45,[\mathrm{M}+3 \mathrm{H}]^{3+}\right), 477(50$, $\left.[\mathrm{M}+4 \mathrm{H}+\mathrm{TFA}]^{4+}\right), 450\left(58,[\mathrm{M}+4 \mathrm{H}]^{4+}\right), 360\left(17,[\mathrm{M}+5 \mathrm{H}]^{5+}\right)$. HRMS (ESI): Calcd for $\mathrm{C}_{77} \mathrm{H}_{125} \mathrm{~N}_{35} \mathrm{O}_{16}: 898.0008$; found: $898.0016\left([\mathrm{M}+2 \mathrm{H}]^{2+}\right)$.

Synthesis of $\operatorname{AcP}(\operatorname{Biot})_{2}$

For the preparation of the biotinylated peptide, D-(+)-Biotin was coupled in the amino group of the lysines Mtt localized at the peptidic sequence. Therefore, following the general protocol of the SPPS for growing the peptide, the Mtt protecting group was selectively removed by mechanically stirring the resin with a mixture of DCM/HFIP/TFE/TIS (6.5:2:1:0.5, 2 × $1 \mathrm{~mL}$ per $70 \mathrm{mg}$ of resin) for $2 \mathrm{~h}$. Finally, the mixture was filtered and the resin was washed with DCM ( 2 x $2 \mathrm{~mL}, 2 \mathrm{~min})$ and DMF (2 mL, $20 \mathrm{~min})$. Then, a solution of D-(+)-Biotin (2 .5 equiv) and N-HATU (2.5 equiv) in DMF $(1 \mathrm{~mL})$ was added to the vessel followed by the drop wise addition of DIEA (4 equiv). The resulting mixture was shaken by bubbling Ar for $30 \mathrm{~min}$ and finally the filtered resin was washed with DMF (3 x 2 ml, 2 min) and DCM (3 x 2 ml, 2 min) (Fig. S11).

$\operatorname{AcP}(\text { Biot })_{2}$ was obtained after RP-HPLC purification [Phenomenex Luna C18(2) 100A column, $\mathrm{H}_{2} \mathrm{O}(0.1 \%$ TFA)/ $\mathrm{CH}_{3} \mathrm{CN}(0.1 \%$ TFA) 95:5 $\rightarrow 5: 95(0 \rightarrow 5 \mathrm{~min}), 95: 5 \rightarrow 5: 95(5 \rightarrow 35 \mathrm{~min})]$ with an overall yield of $11 \%$ and $100 \%$ purity. $R_{\mathrm{t}} 4.1 \mathrm{~min}$ (Fig. S28) [RP-HPLC Agilent SB-C18 column, $\mathrm{H}_{2} \mathrm{O}(0.1 \% \mathrm{TFA}) / \mathrm{CH}_{3} \mathrm{CN}(0.1 \% \mathrm{TFA})$ 95:5 $\rightarrow 5: 95(0 \rightarrow 5 \mathrm{~min})] .{ }^{1} \mathbf{H}$ NMR $\left(500 \mathrm{MHz}, \mathrm{D}_{2} \mathrm{O}, \delta\right): 4.52-4.39(\mathrm{~m}, 2 \mathrm{H}), 4.34-4.22(\mathrm{~m}, 2 \mathrm{H}), 4.22-3.83(\mathrm{~m}$, $13 \mathrm{H}), 3.22-2.95(\mathrm{~m}, 20 \mathrm{H}), 2.90-2.74(\mathrm{~m}, 2 \mathrm{H}), 2.69-2.53(\mathrm{~m}, 2 \mathrm{H}), 2.10(\mathrm{~s}, 3 \mathrm{H}), 1.97-1.88(\mathrm{~m}, 2 \mathrm{H}), 1.88-1.14(\mathrm{~m}$, $63 \mathrm{H}), 0.84-0.65(\mathrm{~m}, 30 \mathrm{H})$. MS (ESI, $\left.\mathrm{H}_{2} \mathrm{O}\right): 1362\left(10,[\mathrm{M}+2 \mathrm{H}+4 \mathrm{TFA}]^{2+}\right), 1306\left(32,[\mathrm{M}+2 \mathrm{H}+3 \mathrm{TFA}]^{2+}\right), 1249(30$, $\left.[\mathrm{M}+2 \mathrm{H}+2 \mathrm{TFA}]^{2+}\right), 1191\left(7,[\mathrm{M}+2 \mathrm{H}+\mathrm{TFA}]^{2+}\right), 870\left(18,[\mathrm{M}+3 \mathrm{H}+3 \mathrm{TFA}]^{3+}\right), 832\left(80,[\mathrm{M}+3 \mathrm{H}+2 \mathrm{TFA}]^{3+}\right), 795(100$ $\left.[\mathrm{M}+3 \mathrm{H}+\mathrm{TFA}]^{3+}\right), 756\left(35,[\mathrm{M}+3 \mathrm{H}]^{3+}\right), 624\left(20,[\mathrm{M}+4 \mathrm{H}+2 \mathrm{TFA}]^{4+}\right), \quad 596\left(25,[\mathrm{M}+4 \mathrm{H}+\mathrm{TFA}]^{4+}\right), 567 \quad(40$, $\left.[\mathrm{M}+4 \mathrm{H}]^{4+}\right)$. HRMS (ESI): Calcd for $\mathrm{C}_{100} \mathrm{H}_{186} \mathrm{~N}_{38} \mathrm{O}_{18} \mathrm{~S}_{2}$ : 1135.7120 ; found: $1135.7119\left([\mathrm{M}+2 \mathrm{H}]^{2+}\right)$.

\section{Preparation of Dexamethasone labelled Concanavalin A}


Dexamethasone-NHS was prepared by the reaction of Ox-Dex ${ }^{\mathrm{S} 2}(0.106 \mathrm{mmol})$ with N-Hydroxysuccinimide $(1.5$ equiv) in DMF, using EDC (1 equiv) and DMAP (cat.) for $4 \mathrm{~h}$. The DMF was removed by rotary evaporation and the oil obtained was dried. The compound was washed with $1 \mathrm{M}$ solution of $\mathrm{HCl}$ and after that with a saturated solution of $\mathrm{NaHCO}_{3}$. Purification by silica gel column chromatography (DCM/MeOH, 99:1) provided final product with an overall yield of $35 \%$.

${ }^{1}$ H NMR $\left(500 \mathrm{MHz}, \mathrm{CDCl}_{3}, \delta\right): 7.22(\mathrm{~d}, J=10.1 \mathrm{~Hz}, 1 \mathrm{H}), 6.32(\mathrm{dd}, J=10.1,1.9 \mathrm{~Hz}, 1 \mathrm{H}), 6.12(\mathrm{~s}, 1 \mathrm{H}), 4.37(\mathrm{~d}, J$ $=8.1 \mathrm{~Hz}, 1 \mathrm{H}), 3.22(\mathrm{~s}, 1 \mathrm{H}), 3.12-2.97(\mathrm{~m}, 1 \mathrm{H}), 2.84(\mathrm{~s}, 4 \mathrm{H}), 2.63(\mathrm{td}, J=13.8,13.0,6.1 \mathrm{~Hz}, 1 \mathrm{H}), 2.49-2.17(\mathrm{~m}$, $4 \mathrm{H}), 1.87-1.72(\mathrm{~m}, 3 \mathrm{H}), 1.63-1.56(\mathrm{~m}, 1 \mathrm{H}), 1.55(\mathrm{~s}, 3 \mathrm{H}), 1.35-1.28(\mathrm{~m}, 2 \mathrm{H}), 1.22(\mathrm{~s}, 3 \mathrm{H}), 1.07(\mathrm{~d}, J=7.1 \mathrm{~Hz}, 3 \mathrm{H})$. ${ }^{13}$ C NMR (500 MHz, $\left.\mathrm{CDCl}_{3}, \delta\right): 186.56$ (q), 168.40 (q), 166.04 (q), 152.12 (CH), $129.81(\mathrm{CH}), 125.13(\mathrm{CH})$, 101.02 (q), 99.62 (q), 86.46 (q), $71.99(\mathrm{CH}), 48.62$ (q), 48.17 (q), $42.96(\mathrm{CH}), 37.01(\mathrm{CH}), 35.88\left(\mathrm{CH}_{2}\right), 34.32$ (CH), $32.35\left(\mathrm{CH}_{2}\right), 30.99\left(\mathrm{CH}_{2}\right), 29.70\left(\mathrm{CH}_{2}\right), 25.67\left(\mathrm{CH}_{2}\right), 22.90\left(\mathrm{CH}_{3}\right), 16.70\left(\mathrm{CH}_{3}\right), 14.57\left(\mathrm{CH}_{3}\right)$. (Fig. S29).

HRMS (ESI): Calcd for $\mathrm{C}_{25} \mathrm{H}_{31} \mathrm{FNO}_{7}$ : 476.2082; found: 476.2079.

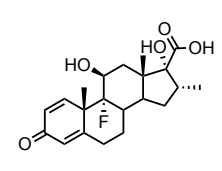

Ox-Dex

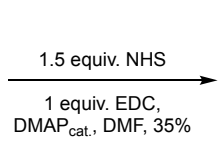

DMAP $_{\text {cat. }}$, DMF, $35 \%$

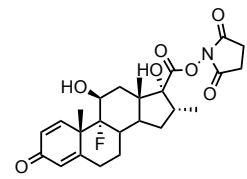

DexNHS

Synthesis of ConA-Dex

ConA-Dex was prepared by the reaction of Concanavalin A (3 mg/mL) with Dexamethasone-NHS (50 equiv) in $\mathrm{NaHCO}_{3}$ buffer ( $\mathrm{pH}$ ) at room temperature for $2 \mathrm{~h}$. The resulting solution was dialysed overnight in HKR buffer. To quantify the number of dexamethasones per Concanavalin A the absorbance of the mixture was measured using a NanoDrop UV-Vis Spectrophotometer. Absorbance values at $242 \mathrm{~nm}$ (maximum absorbance for dexamethasone) and $280 \mathrm{~nm}$ (maximum absorbance for the protein) were measured for various dilutions of the dialysed ConA-Dex, and several known concentrations of ConA or dexamethasone. Data in the linear range were analysed using the following system of equations:

$$
\begin{aligned}
& A_{242}^{\text {ConA-Dex }}=x \cdot A_{242}^{\text {ConA }}+y \cdot A_{242}^{\text {Dex }} \\
& A_{280}^{\text {ConA-Dex }}=x \cdot A_{280}^{\text {ConA }}+y \cdot A_{280}^{\text {Dex }}
\end{aligned}
$$

Where the values $x$ and $y$ were used to estimate the concentration of each component in ConA-Dex by multiplying the concentration of pure ConA or dexamethasone by $x$ or $y$ respectively, and the extent of labelling was calculated as the ratio between dexamethasone and ConA concentrations. A value of around 16 Dex per ConA tetramer was obtained.

\section{General Procedure for Circular Dichroism}


Circular dichroism measurements were carried out using the following settings: acquisition range: $300-190 \mathrm{~nm}$; band width: $1.0 \mathrm{~nm}$; accumulation: 3 scans; data pitch: $1 \mathrm{~nm}$; CD scale $200 \mathrm{mdeg} / 1.0 \mathrm{dOD}$; D.I.T. (Data Integration Time): $1 \mathrm{~s}$; scanning mode: continuous; scanning speed: $200 \mathrm{~nm} / \mathrm{min}$. Measurements were done from $10{ }^{\circ} \mathrm{C}$ to $60{ }^{\circ} \mathrm{C}$ (data interval: $10{ }^{\circ} \mathrm{C}$; temp. gradient $5{ }^{\circ} \mathrm{C} / \mathrm{min}$ ) in a quartz cell of $0.2 \mathrm{~cm}$ path length at a final volume of $0.5 \mathrm{~mL}$ (HKR buffer or TFE) with a final peptide concentration of $200 \mu \mathrm{M}$.

For the measurements in liposomes, samples were prepared by drying under reduced pressure L- $\alpha$ phosphatidylcholine $\left(8.5 \mu \mathrm{L}, 100 \mathrm{mg} / \mathrm{mL}\right.$ solution in $\left.\mathrm{CHCl}_{3}\right)$ and peptide $(325 \mu \mathrm{L}, 200 \mu \mathrm{M})$ in $\mathrm{TFE}$ to obtain a ratio lipid/peptide of 18:1. Lipids were suspended in HKR buffer $(650 \mu \mathrm{L})$ and sonicated for 45 min until a clear solution was obtained. Spectra were recorded in a $0.2 \mathrm{~cm}$ path length quartz cell.

The results are expressed as the mean residue molar ellipticity $[\theta]_{M R t}$ with units of degrees $\cdot \mathrm{cm}^{2} \cdot \mathrm{dmol}^{-1}$ and calculated using the equation $\mathrm{S} 1$,

$$
[\theta]_{\text {MRt }}=\frac{100 \cdot \theta}{C \cdot l \cdot \text { No. of residues }}
$$

where $\theta$ is the ellipticity (mdeg), $C$ is the peptide concentration (M) and $l$ is the cell path length (cm).

$$
[\theta] \%=\frac{\theta M R t_{222}-2340}{30300} \times 10
$$

Formula to calculate the percent of helicity in where the molar ellipticity at $222 \mathrm{~nm}$ is an absolute value.

\section{Cells Lines and Culture}

HeLa cells were incubated at $37{ }^{\circ} \mathrm{C} / 5 \% \mathrm{CO}_{2} / 95 \%$ humidity in an INCO 108 incubator (Memmert) with Dulbecco's Modified Eagle's Medium (4500 mg/L glucose, L-glutamine, sodium pyruvate and sodium bicarbonate; Sigma-Aldrich), supplemented with 10\% fetal bovine serum (Sigma-Aldrich) and 1\% of PenicillinStreptomycin-Glutamine Mix (Fisher).

\section{Cell transport experiments in HepG2 cells}

Internalization experiments in HepG2 cells were done as described for HeLa cells (see Methods in the manuscript). In the case of streptavidin, incubation time was increased to $5 \mathrm{~h}$.

\section{Cell viability: MTT Assay}

Cell viability was established by a standard MTT assay (Fig. S7 and S8). One day before the assay, a suspension of HeLa or HepG2 cells was plated in 96-well tissue culture plates (Costar 96 Flat Bottom Transparent Polystyrol) by adding $100 \mu \mathrm{L}(150.000 \mathrm{cells} / \mathrm{mL})$ per well. The next day, the medium was aspirated and cells 
were incubated with different concentrations of peptide and peptide/protein complexes diluted in HKR (50 $\mu \mathrm{L} /$ well). After $30 \mathrm{~min}$ of incubation at $37^{\circ} \mathrm{C}$, the medium was aspirated and replaced by fresh medium (DMEM) containing $10 \%$ FBS $(100 \mu \mathrm{L})$. Control cells were given only cell culture medium (100 $\mu \mathrm{L}$ final medium). The viability was measured by quantifying the cellular ability to reduce the water-soluble tetrazolium dye 3-(4,5dimethyl-2-thiazolyl)-2,5-diphenyl tetrazolium bromide (MTT) to its insoluble formazan salt as follows. MTT (5 $\mathrm{mg} / \mathrm{mL}$ in PBS, $10 \mu \mathrm{L} /$ well) was added to the wells and the cells were further incubated for $6 \mathrm{~h}$. The supernatant was carefully removed and the water-insoluble formazan salt was dissolved in DMSO (100 $\mu \mathrm{L} / \mathrm{well})$. The absorbance was measured at $570 \mathrm{~nm}$ using a microplate reader (Infinite F200pro, Tecan). Data points were collected in triplicate and expressed as normalized values for untreated control cells (100\%).

\section{Propidium Iodide Assay}

Cell viability was established by a standard PI assay (Fig. S7 and S8). One day before the assay, a suspension of HeLa or HepG2 cells was plated in 96-well tissue culture plates (Costar 96 Flat Bottom Transparent Polystyrol) by adding $100 \mu \mathrm{L}(150.000$ cells $/ \mathrm{mL})$ per well. The next day, the medium was aspirated and cells were incubated with different concentrations of peptide and peptide/protein complexes diluted in DMEM (50 $\mu \mathrm{L} /$ well). After 30 min of incubation at $37{ }^{\circ} \mathrm{C}$, the medium was aspirated; cells were washed with fresh medium and then $100 \mu \mathrm{L}$ of trypsin were added in each well and cells were incubated for $15 \mathrm{~min}$ at $37^{\circ} \mathrm{C}$. After this, $100 \mu \mathrm{L}$ of a solution of 2\% FBS and $5 \mathrm{mM}$ EDTA in PBS containing PI $(0.25 \mu \mathrm{g} / \mathrm{mL})$ were added and the plate was incubated for $5 \mathrm{~min}$

in the dark. Samples were analysed on a Guava EasyCyte ${ }^{\mathrm{TM}}$ cytometer. Propidium iodide was measured by excitation at $532 \mathrm{~nm}$ and collecting emission at 695/50 nm. Data points were collected in triplicate and analysis was performed with InCyte software included in GuavaSoft 3.2 (Millipore).

\section{Quantification of the uptake by fluorometry}

For internalization assays, a modification of the quantification of CPP uptake by fluorometry protocol described in Holm et al. ${ }^{[5]}$ was used. Briefly, semiconfluent monolayers of HeLa cells seeded the day before were washed twice with HKR before incubation with $4 \mu \mathrm{M}$ of TAMRA labelled peptides, with $\mathrm{TmP}(\mathrm{Man})_{2} / \mathrm{ConA}$ or with $\mathrm{AcP}(\mathrm{Man})_{2} / \mathrm{ConA}_{\mathrm{FITC}}$ complexes (previously prepared by co-incubation for $7 \mathrm{~min} \mathrm{rt}$ ) diluted in the same buffer for $30 \mathrm{~min}$ at $37^{\circ} \mathrm{C}$ (unless otherwise stated). Then, cells were washed twice with HKR and trypsinized, and after the addition of $1 \mathrm{~mL}$ of HKR, centrifuged for $5 \mathrm{~min}$ at $1000 \mathrm{~g}$. The resultant pellets were lysed by incubation in aqueous solution of $\mathrm{NaOH}(0.1 \mathrm{M})$ at $4{ }^{\circ} \mathrm{C}$ for $60 \mathrm{~min}$ and frozen until analysis.

Where indicated, cells were pretreated for $30 \mathrm{~min}$ before the incubation of the peptide and during the incubation with the following inhibitors: Wortmannin $(200 \mathrm{nM})$, chlorpromazine $(30 \mu \mathrm{M})$, methyl- $\beta$-cyclodextrin $(5 \mathrm{mM})$, EIPA $(50 \mu \mathrm{M})$, ammonium chloride $(50 \mathrm{mM})$, chloroquine $(100 \mu \mathrm{M})$ or heparin $(5 \mu \mathrm{g} / \mathrm{mL})$. For the incubation at low temperature, cells were placed on ice $15 \mathrm{~min}$ before the incubation with the peptides, and ice-cold solutions were used for the washes and incubation. 
Fluorescence levels of the lysates were measured using a microplate reader (Infinite F200Pro, Tecan), both for TAMRA ( $\left.\lambda_{\text {ex }} 560 \mathrm{~nm}, \lambda_{\mathrm{em}} 610 \mathrm{~nm}\right)$ and fluorescein $\left(\lambda_{\mathrm{ex}} 485 \mathrm{~nm}, \lambda_{\mathrm{em}} 535 \mathrm{~nm}\right.$ ) labelled compounds, and the concentration of the peptides or ConA was calculated by comparison to a standard curve. After neutralization with a volume of an aqueous solution of $\mathrm{HCl}(0.1 \mathrm{M})$, protein concentration in the lysates was determined using a Coomassie (Bradford) protein assay kit following the manufacturer instructions, and measuring the absorbance at $570 \mathrm{~nm}$ (Infinite F200Pro, Tecan). The uptake was calculated as pmol of peptide/mg of total protein, and normalized to the uptake in untreated cells in the case of the inhibition studies.

\section{Glucocorticoid assay}

The ability of the peptide to reach the cytosol was determined with a glucocorticoid induced GFP translocation assay $(\mathrm{GIGT})^{[6]}$. In this assay, a GFP protein fused to the steroid binding domain of the glucocorticoid receptor (GR) accumulates in the nucleus of the cell in response to dexamethasone binding, so the translocation ratio (the ratio between the nuclear and cytoplasmic fluorescence) can be used as an indicator of the presence of dexamethasone-labelled peptides in the cytosol (Fig. S9).

HeLa cells grown in four chamber glass bottom dishes were transfected with the plasmid pK7-GR-GFP (a gift from Ian Macara ${ }^{[7]}$, Addgene plasmid \#15534) using Lipofectamine 2000 and, 24 h post-transfection, cells were washed with HKR and incubated for 30 min with Hoechst $33342(1 \mu \mathrm{M})$, and endocytosis inhibitors where indicated, at the following concentrations: chlorpromazine $(50 \mu \mathrm{M})$, methyl- $\beta$-cyclodextrin $(5 \mathrm{mM})$, Wortmannin (200 $\mathrm{nM})$, chloroquine $(100 \mu \mathrm{M}), \mathrm{NH}_{4} \mathrm{Cl}(50 \mathrm{mM})$, heparin $(5 \mu \mathrm{g} / \mathrm{mL})$ or EIPA $(50 \mu \mathrm{M})$. Cells were then incubated for $1 \mathrm{~h}$ with $\operatorname{DexP}(\operatorname{Man})_{2}(4 \mu \mathrm{M})$, in the presence or absence of unlabelled ConA (30 nM), with dexamethasone $(1 \mu \mathrm{M})$ (as positive control) or just with HKR (as negative control) and immediately imaged. To study the cytosolic release of ConA-Dex, cells were incubated with $7 \mathrm{nM}$ of Dex-labelled ConA (equivalent to around $100 \mathrm{nM}$ Dexamethasone) previously incubated with $4 \mu \mathrm{M}$ of $\mathrm{AcP}(\mathrm{Man})_{2}$. As controls, cells were incubated with the same amount of ConA-Dex in the absence of peptide or after incubation for 20 min with $1 \mu \mathrm{g}$ of Lipofectamine 2000. Twenty to thirty images of each sample were acquired with an Andor Zyla 4.2 digital camera mounted on a Nikon Eclipse Ti-E microscope at 60x magnification and the translocation ratio (the ratio of the median intensities of GFP in the nucleus and in the $2 \mu \mathrm{m}$ wide surrounding region) was calculated with CellProfiler ${ }^{[8]}$ as follows. Nuclei were identified as Hoechst stained objects using the three-class thresholding Otsu method and the cytoplasmic region was defined as the $2 \mu \mathrm{m}$ surrounding area. To ensure a better separation of the cytoplasmic and nuclear region, nuclei were shrunk $0.5 \mu \mathrm{m}$ before measuring object intensity. Cells falling below the $20 \%$ of the maximum intensity of the image were considered untransfected and discarded for the analysis. A total of 40 to 80 cells were analyzed for each sample.

Statistical analysis of the data was performed with $\mathrm{R}$ software ${ }^{\mathrm{S}[9]}$. Results were subjected to pairwise two-tailed Student's t-test and p-values were adjusted using Bonferroni's correction. 


\section{Time-lapse videos}

For time-lapse experiments, HeLa cells incubated with the peptide/protein complexes were placed in an incubator chamber at $37^{\circ} \mathrm{C}$ on a Nikon Eclipse Ti-E inverted microscope. The acquisition of the images was controlled with NIS-Elements software (Nikon), using the indicated time intervals. Videos were assembled using ImageJ.

\section{Gel electrophoresis}

To study protein degradation, HeLa cells were incubated with the mixtures of ConA (FITC- or biotin-labelled) and $\mathrm{AcP}(\mathrm{Man})_{2}$ for $30 \mathrm{~min}$ in $\mathrm{HKR}$ at $37^{\circ} \mathrm{C}$. Cells were washed with $\mathrm{HKR}$, trypsinized and centrifuged for 5 min at $1000 \mathrm{~g}, 4{ }^{\circ} \mathrm{C}$. Pellets were re-suspended in Laemmli buffer 1x $(60 \mathrm{mM}$ Tris- $\mathrm{HCl} \mathrm{pH}$ 6.8, $2 \%$ SDS, $10 \%$ glycerol, $5 \%$ 2-mercaptoethanol, $0.0010 \%$ bromophenol blue) and boiled for $5 \mathrm{~min}$. Proteins were separated on $12.5 \%$ SDS-PAGE gels.

Gels containing FITC-labelled protein were directly imaged under UV light in a Gel Doc system (Bio-Rad), and then stained with Coomassie blue to ensure similar amounts of protein were loaded in each lane. For the detection of the biotinylated protein, proteins were transferred to a PVDF membrane (Immobilon-P, Millipore), blocked with $5 \%$ BSA in PBS with $0.05 \%$ Tween-20 for $1 \mathrm{~h}$ and incubated with $4 \mu \mathrm{g} / \mathrm{mL}$ of Streptavidin 488 diluted in blocking solution. After several washes, bands were detected under UV light using a Gel Doc system.

\section{Atomic Force Microscopy (AFM).}

Standard AFM measurements (Fig. S15) were conducted in ambient atmosphere at room temperature. Shortly before mica deposition, samples were prepared by incubating a $2 \mu \mathrm{M}$ and $4 \mu \mathrm{M}$ solution of $\mathrm{AcP}(\mathrm{Man})_{2}$ with a 30 $\mathrm{nM}$ solution of ConA in HKR buffer, for 10 min. For AFM imaging, $10 \mu \mathrm{L}$ of the sample were dropped onto freshly exfoliated mica and after 10 min the mica was thoroughly washed with Milli-Q water, and dried under nitrogen flow. 


\section{Supporting Figures for Characterization}

A)

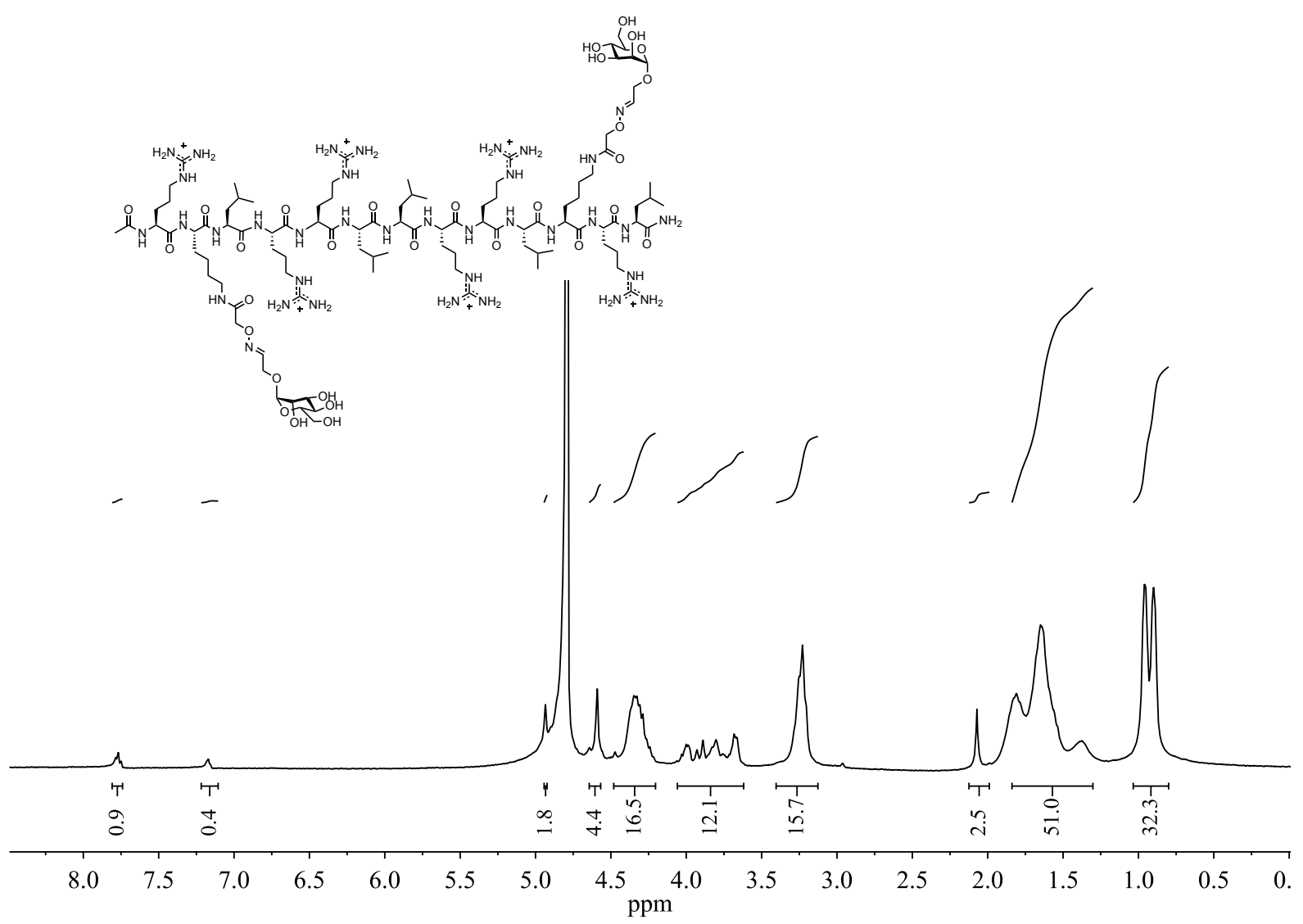

B)
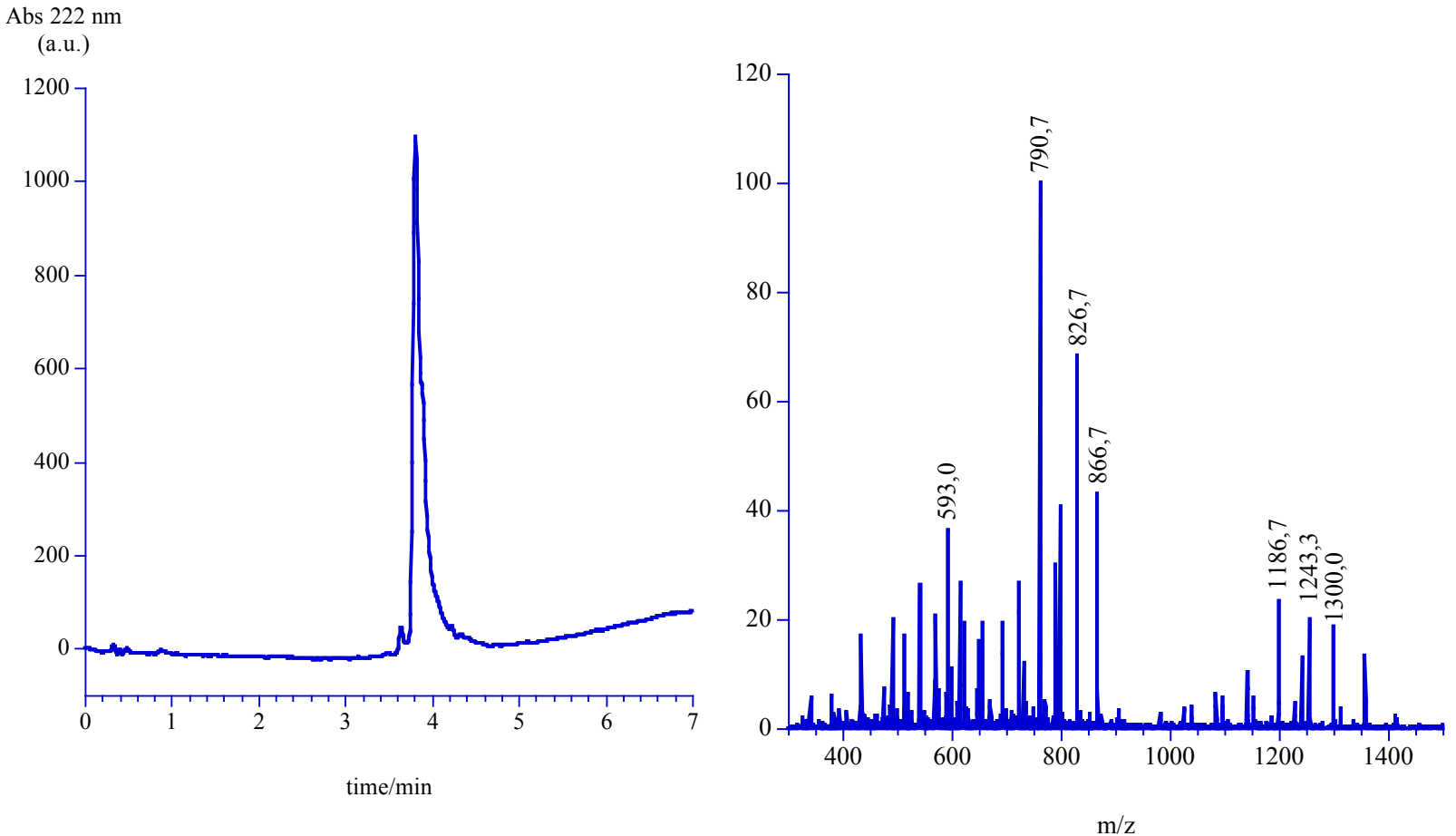

Figure S16. A) ${ }^{1} \mathrm{H}-\mathrm{NMR}$ spectra in $\mathrm{D}_{2} \mathrm{O}$ of $\mathrm{AcP}(\mathrm{Man})_{2}$. B) RP-HPLC [Agilent SB-C18 column, $\mathrm{H}_{2} \mathrm{O}(0.1 \%$ $\mathrm{TFA}) / \mathrm{CH}_{3} \mathrm{CN}(0.1 \%$ TFA) 95:5 $\rightarrow 5: 95(0 \rightarrow 5 \mathrm{~min})]\left(R_{\mathrm{t}} 3.8 \mathrm{~min}\right)$ and ESI-MS for AcP(Man $)_{2}$. 
A)

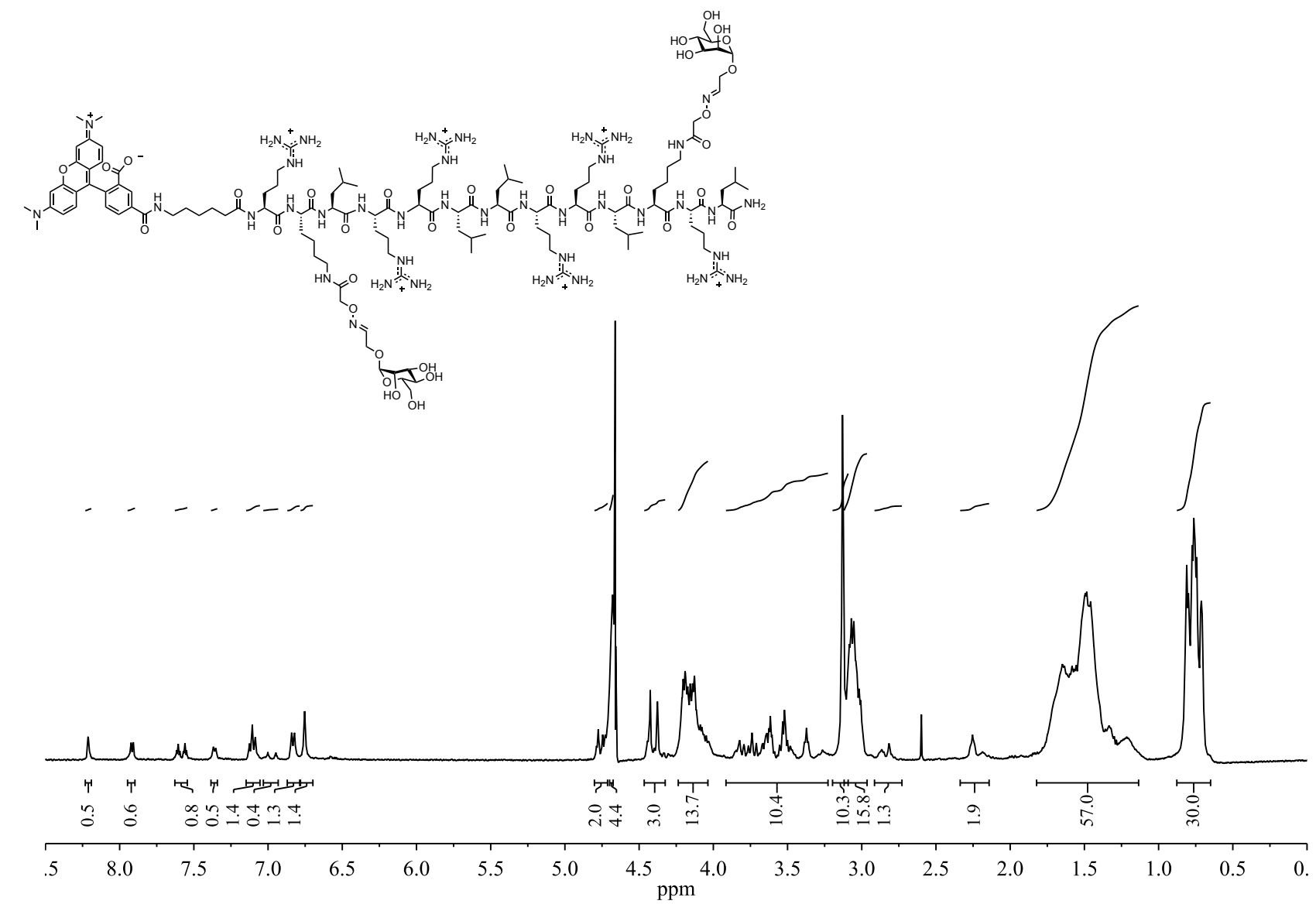

B)
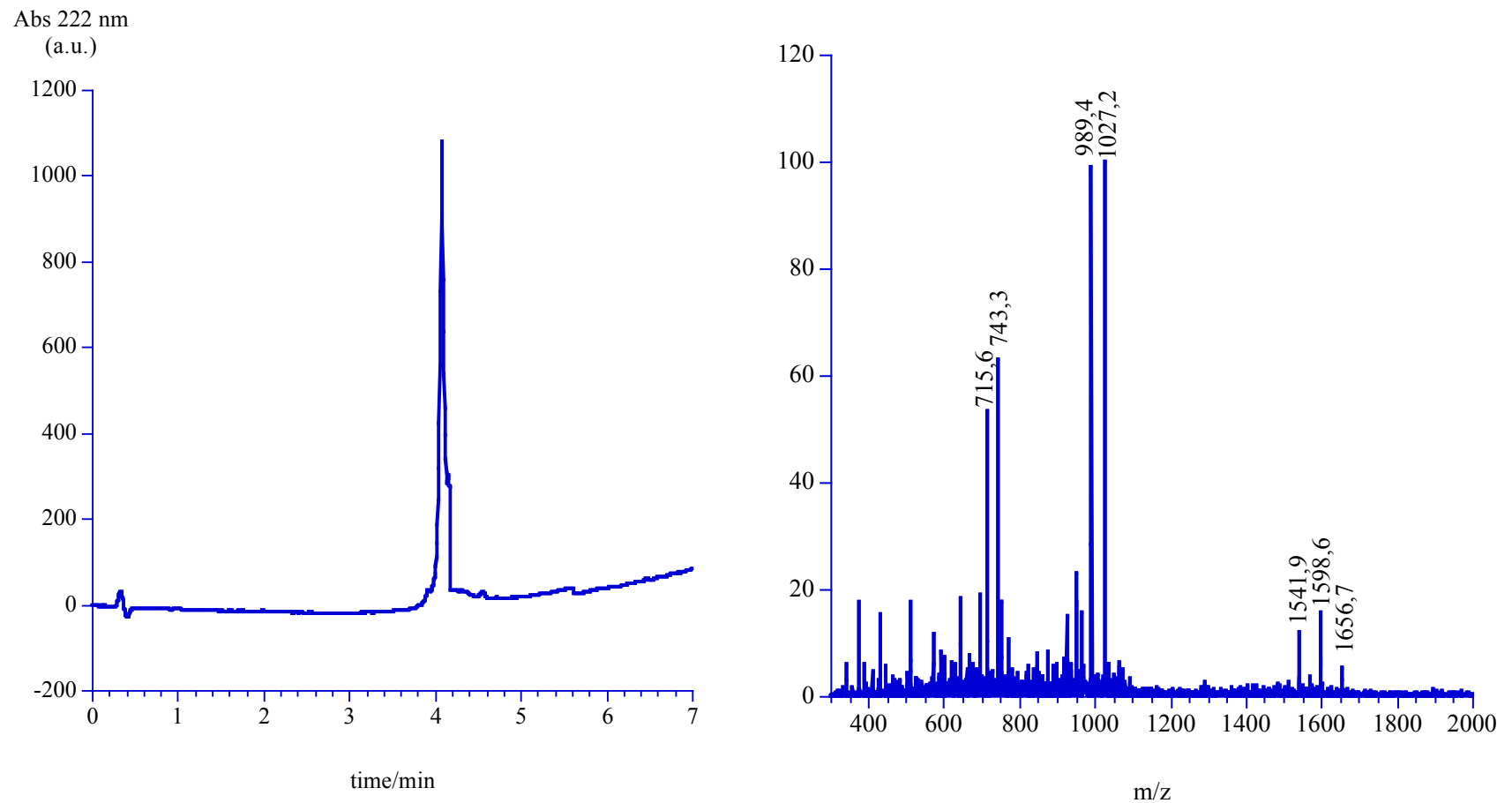

Figure S17. A) ${ }^{1} \mathrm{H}-\mathrm{NMR}$ spectra in $\mathrm{D}_{2} \mathrm{O}$ of TmP(Man) $)_{2}$. B) RP-HPLC [Agilent SB-C18 column, $\mathrm{H}_{2} \mathrm{O}(0.1 \%$ TFA $) / \mathrm{CH}_{3} \mathrm{CN}(0.1 \%$ TFA) 95:5 $\rightarrow 5: 95(0 \rightarrow 5 \mathrm{~min})]\left(R_{\mathrm{t}} 4.1 \mathrm{~min}\right)$ and ESI-MS for TmP(Man $)_{2}$. 

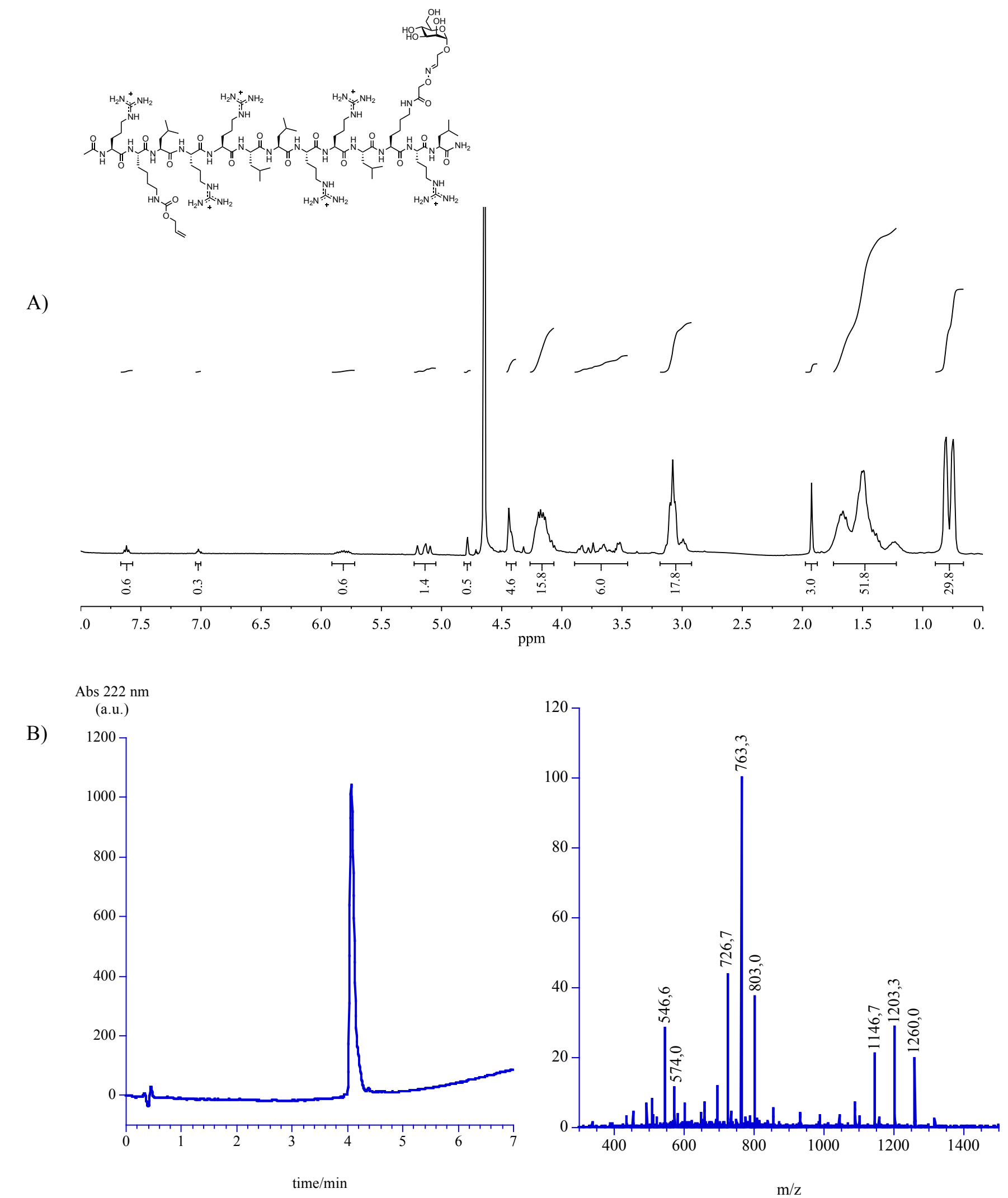

Figure S18. A) ${ }^{1} \mathrm{H}-\mathrm{NMR}$ spectra in $\mathrm{D}_{2} \mathrm{O}$ of AcP(Alloc)(Man). B) RP-HPLC [Agilent SB-C18 column, $\mathrm{H}_{2} \mathrm{O}$ $(0.1 \% \mathrm{TFA}) / \mathrm{CH}_{3} \mathrm{CN}(0.1 \% \mathrm{TFA})$ 95:5 $\left.\rightarrow 5: 95(0 \rightarrow 5 \mathrm{~min})\right]\left(R_{\mathrm{t}} 4.1 \mathrm{~min}\right)$ and ESI-MS for AcP(Alloc)(Man). 


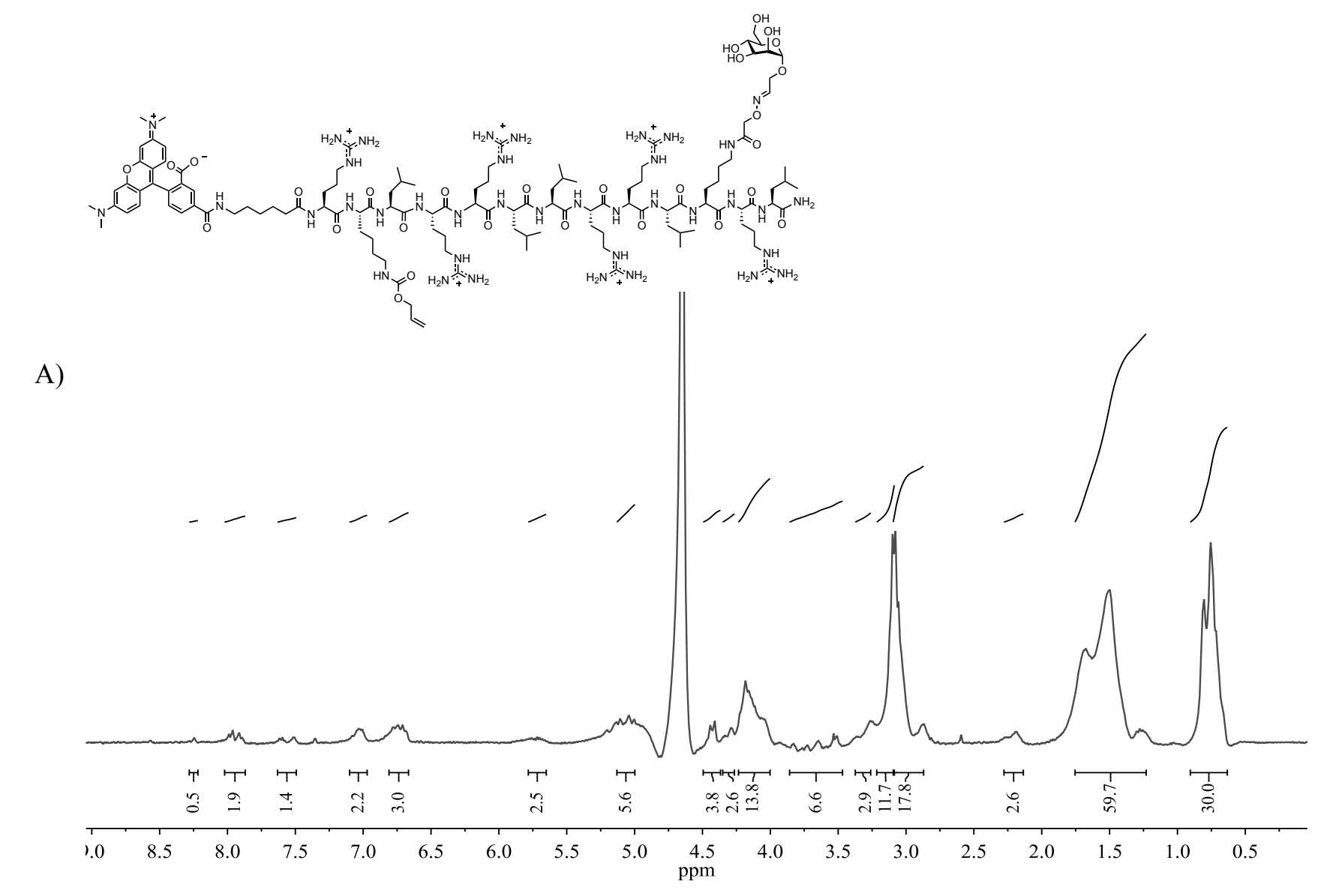

B) $\operatorname{Abs} 222 \mathrm{~nm}$
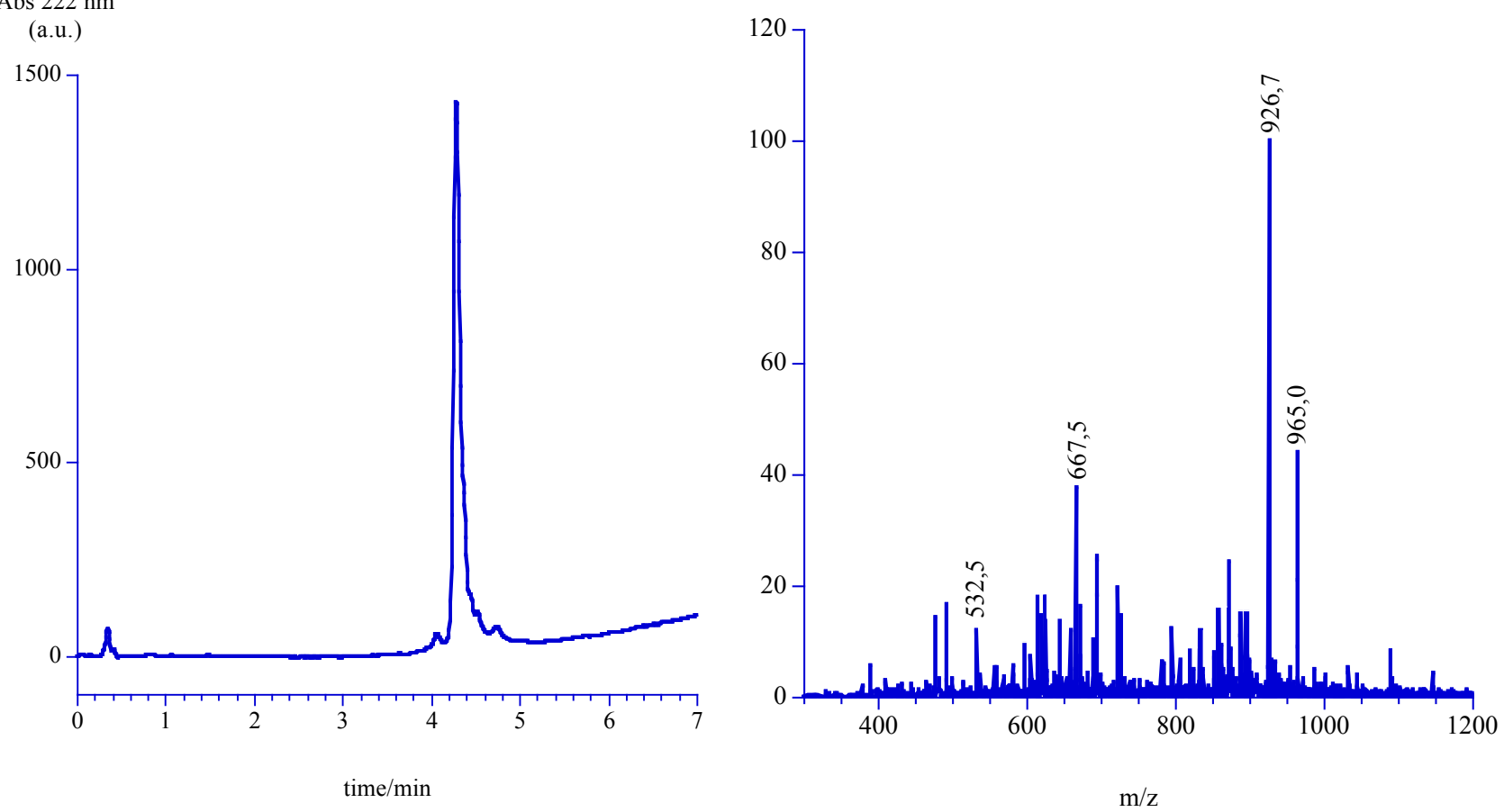

Figure S19. A) ${ }^{1} \mathrm{H}-\mathrm{NMR}$ spectra in $\mathrm{D}_{2} \mathrm{O}$ of $\mathrm{TmP}\left(\right.$ Alloc)(Man). B) RP-HPLC [Agilent SB-C18 column, $\mathrm{H}_{2} \mathrm{O}$ $(0.1 \% \mathrm{TFA}) / \mathrm{CH}_{3} \mathrm{CN}(0.1 \% \mathrm{TFA})$ 95:5 $\left.\rightarrow 5: 95(0 \rightarrow 5 \mathrm{~min})\right]\left(R_{\mathrm{t}} 4.3 \mathrm{~min}\right)$ and ESI-MS for TmP(Alloc)(Man). 

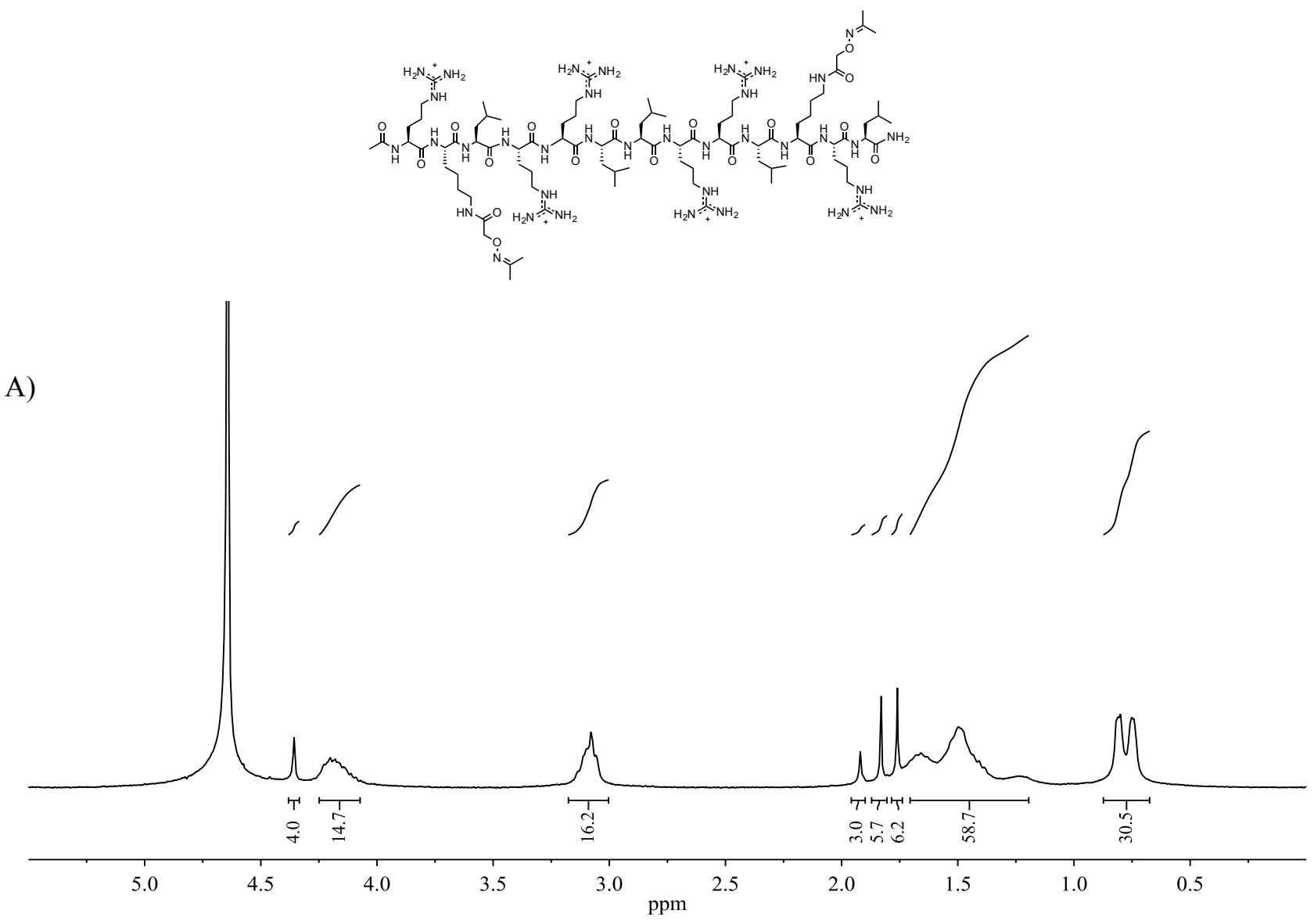

B) $\quad \operatorname{Abs} 222 \mathrm{~nm}$
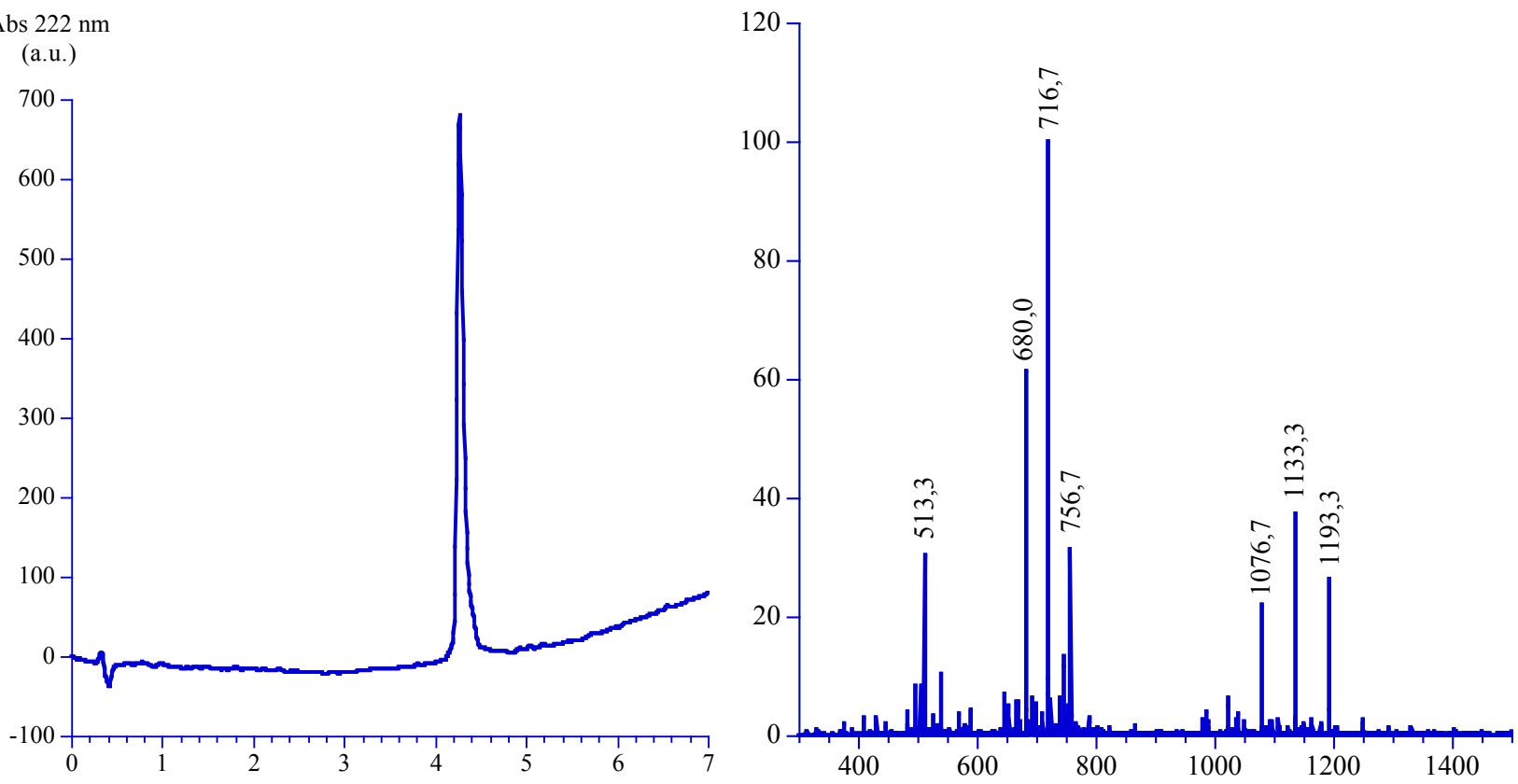

time/min

$\mathrm{m} / \mathrm{z}$

Figure S20. A) ${ }^{1} \mathrm{H}-\mathrm{NMR}$ spectra in $\mathrm{D}_{2} \mathrm{O}$ of $\mathrm{AcP}(\text { Acetone })_{2}$. B) RP-HPLC [Agilent SB-C18 column, $\mathrm{H}_{2} \mathrm{O}(0.1 \%$ TFA)/ $\mathrm{CH}_{3} \mathrm{CN}(0.1 \%$ TFA) 95:5 $\rightarrow 5: 95(0 \rightarrow 5 \mathrm{~min})]\left(R_{\mathrm{t}} 4.3 \mathrm{~min}\right)$ and ESI-MS for AcP(Acetone $)_{2}$. 
A)
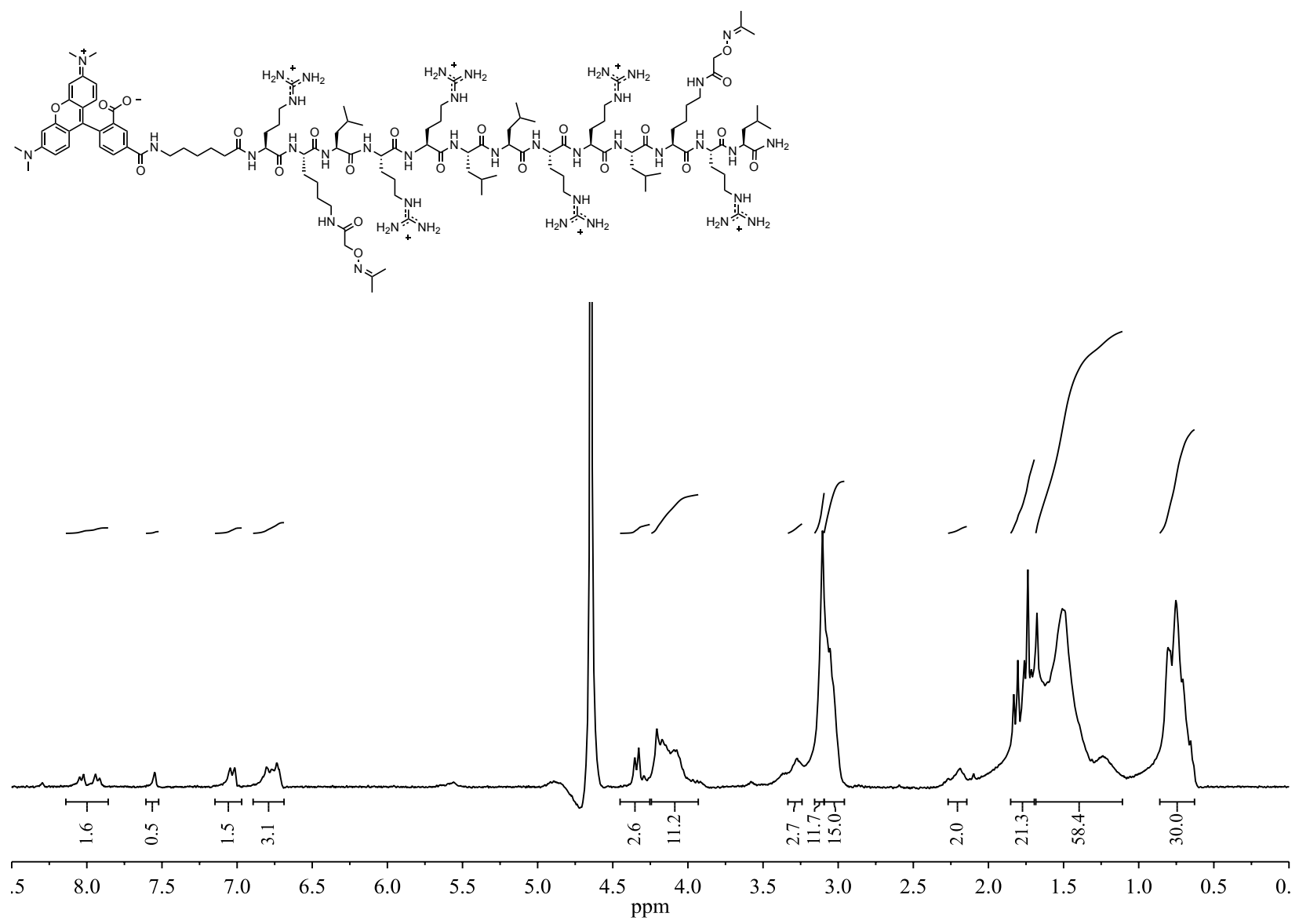

B) $\quad$ Abs $222 \mathrm{~nm}$
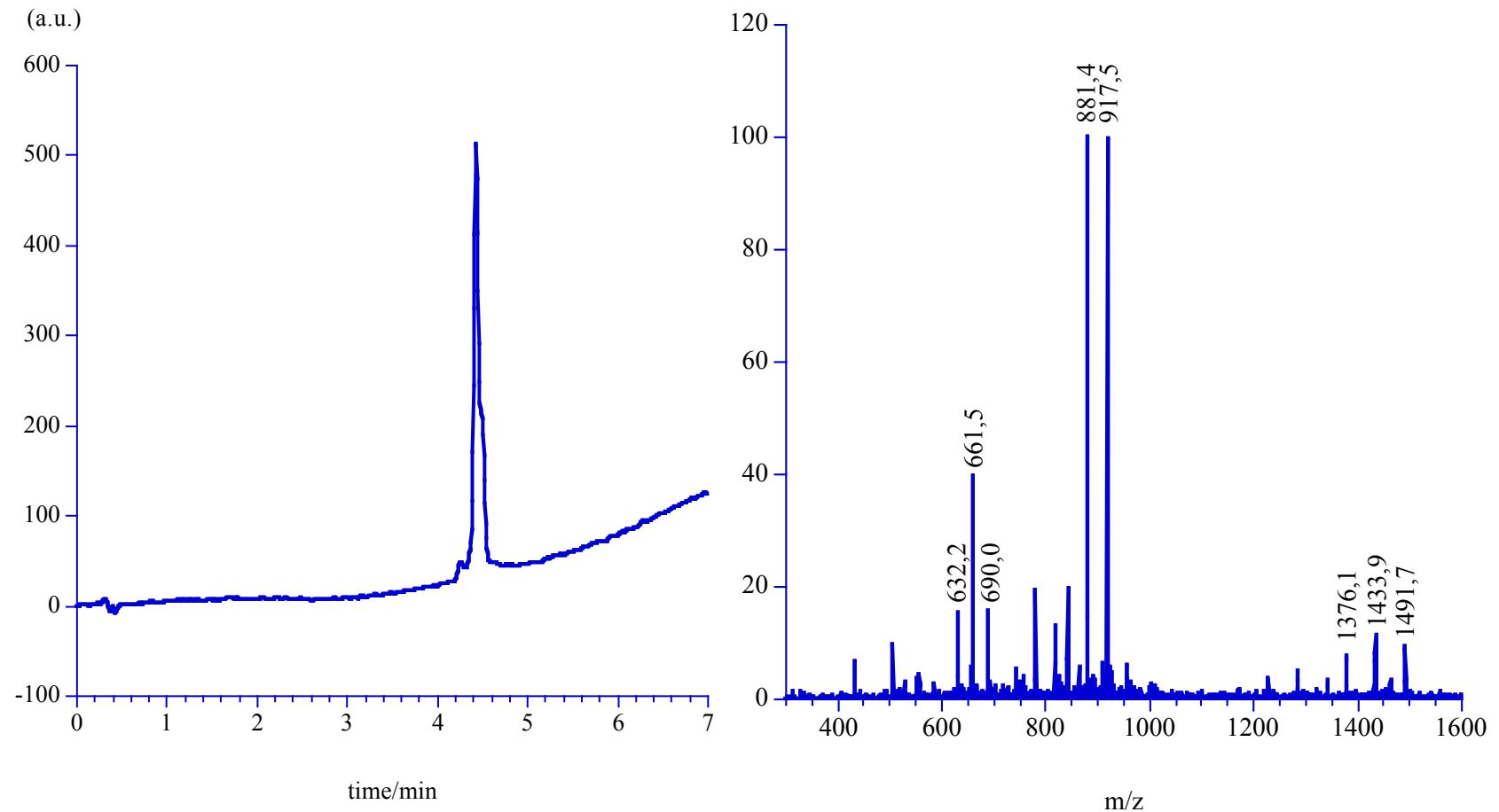

Figure S21. A) ${ }^{1} \mathrm{H}-\mathrm{NMR}$ spectra in $\mathrm{D}_{2} \mathrm{O}$ of TmP(Acetone) $)_{2}$. B) RP-HPLC [Agilent SB-C18 column, $\mathrm{H}_{2} \mathrm{O}(0.1 \%$ TFA)/ $\mathrm{CH}_{3} \mathrm{CN}(0.1 \%$ TFA) 95:5 $\rightarrow 5: 95(0 \rightarrow 5 \mathrm{~min})]\left(R_{\mathrm{t}} 4.4 \mathrm{~min}\right)$ and ESI-MS for TmP(Acetone $)_{2}$. 


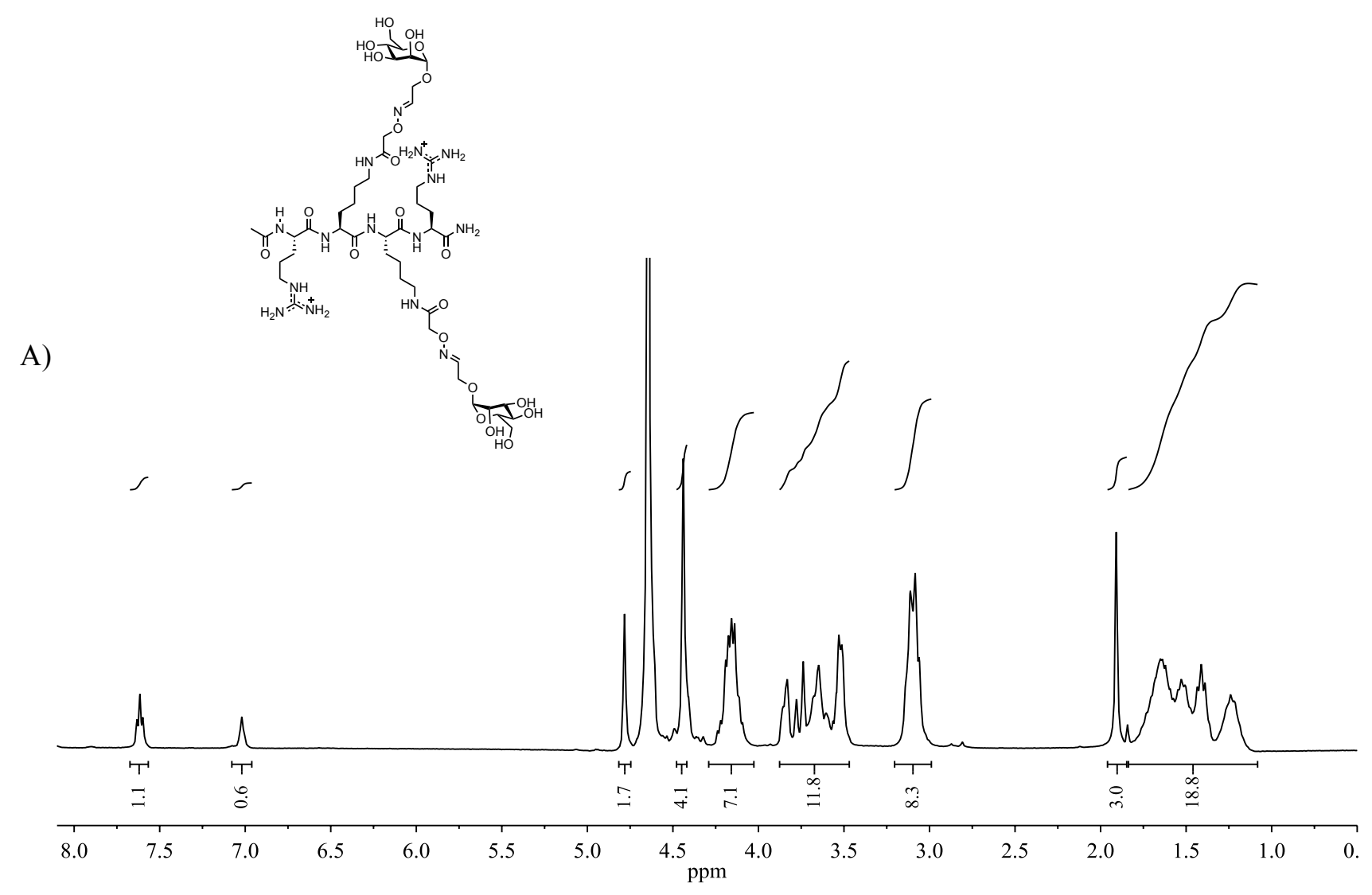

B) $\operatorname{Abs} 222 \mathrm{~nm}$
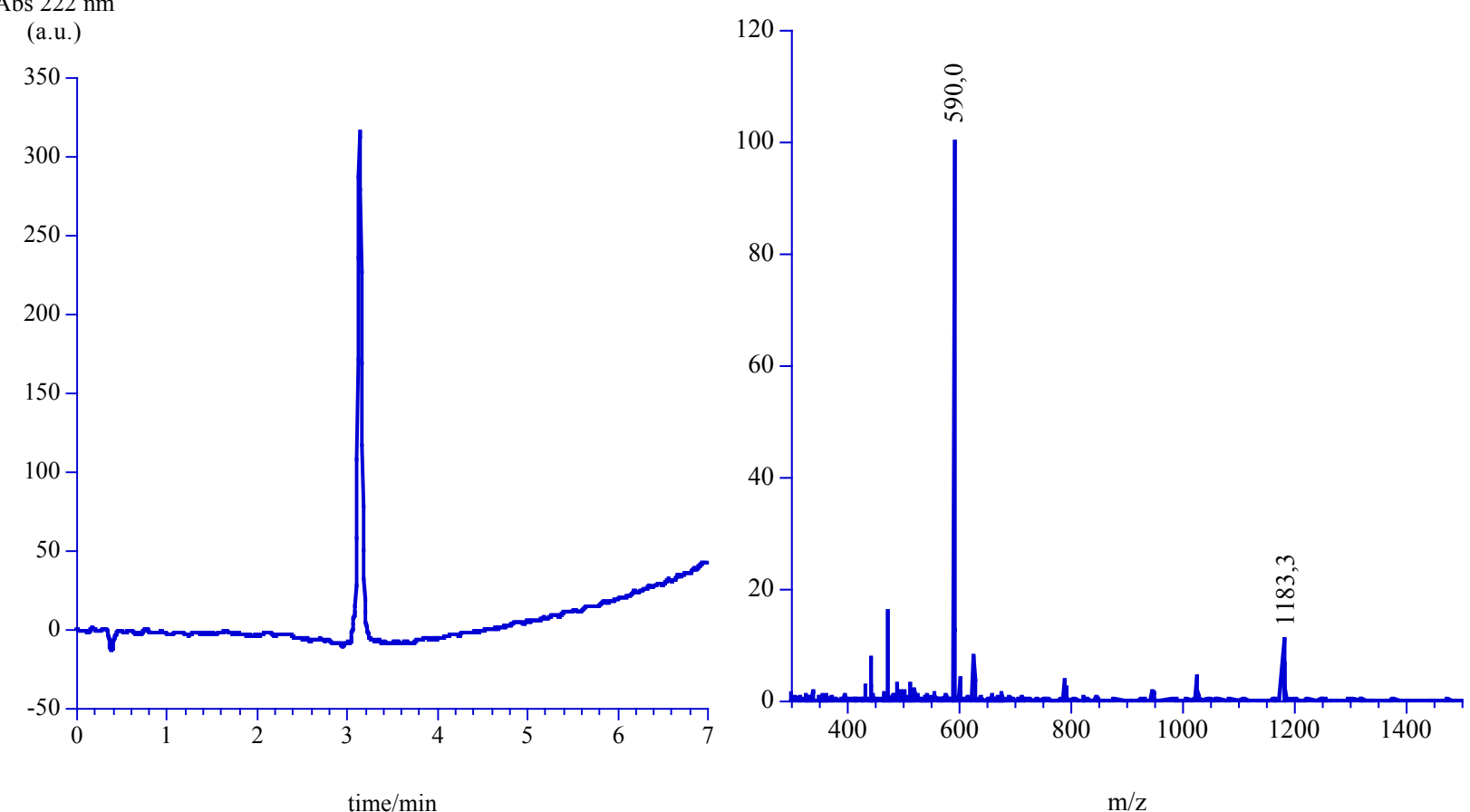

Figure S22. A) ${ }^{1} \mathrm{H}-\mathrm{NMR}$ spectra in $\mathrm{D}_{2} \mathrm{O}$ of $\mathrm{AcArg}_{2}(\mathrm{Man})_{2}$. B) RP-HPLC [Agilent SB-C18 column, $\mathrm{H}_{2} \mathrm{O}(0.1 \%$ $\mathrm{TFA}) / \mathrm{CH}_{3} \mathrm{CN}(0.1 \%$ TFA) 95:5 $\rightarrow 5: 95(0 \rightarrow 5 \mathrm{~min})]\left(R_{\mathrm{t}} 3.1 \mathrm{~min}\right)$ and ESI-MS for $\mathrm{AcArg}_{2}(\mathrm{Man})_{2}$. 


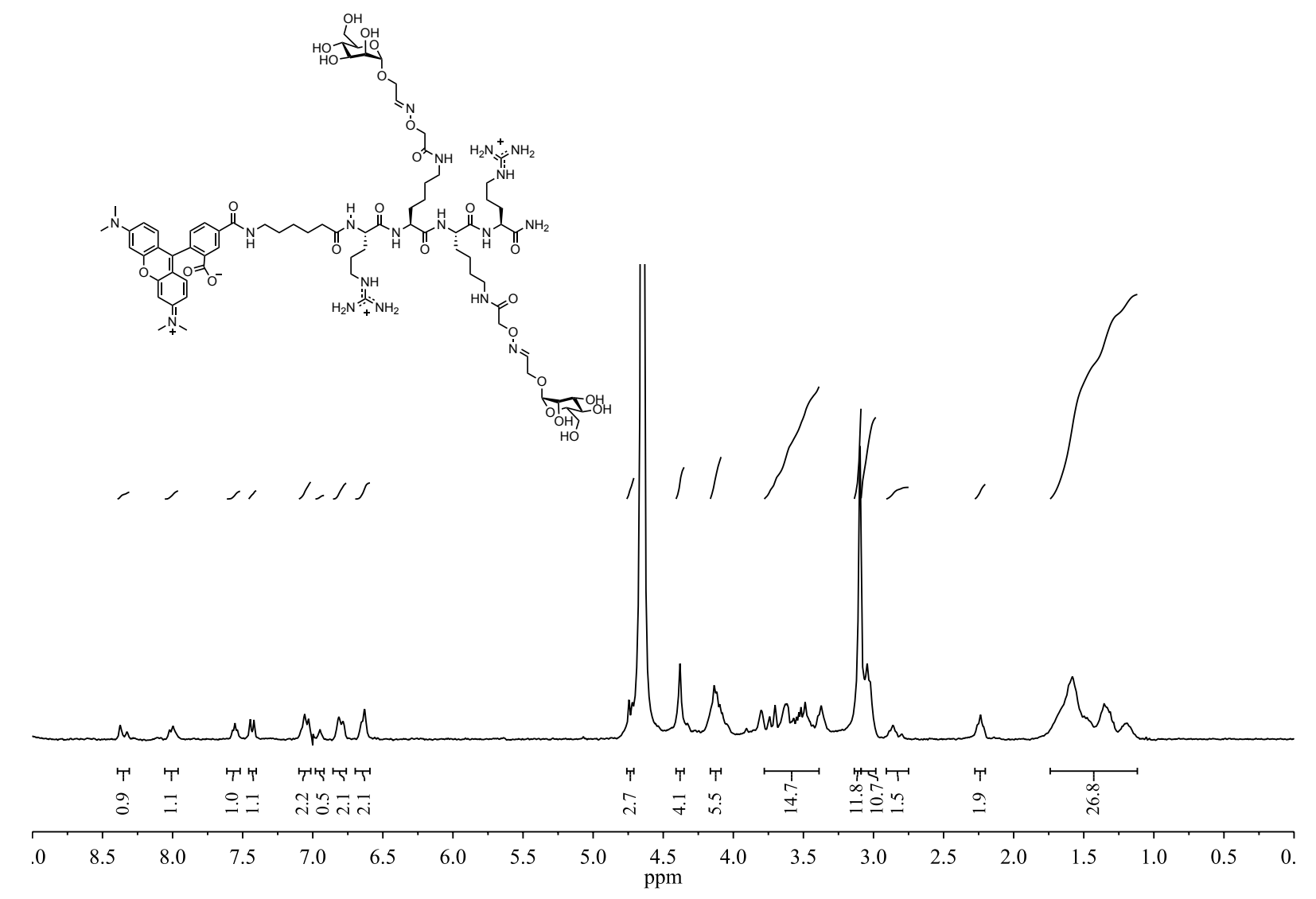

A)

B) Abs $222 \mathrm{~nm}$
(a.u.)
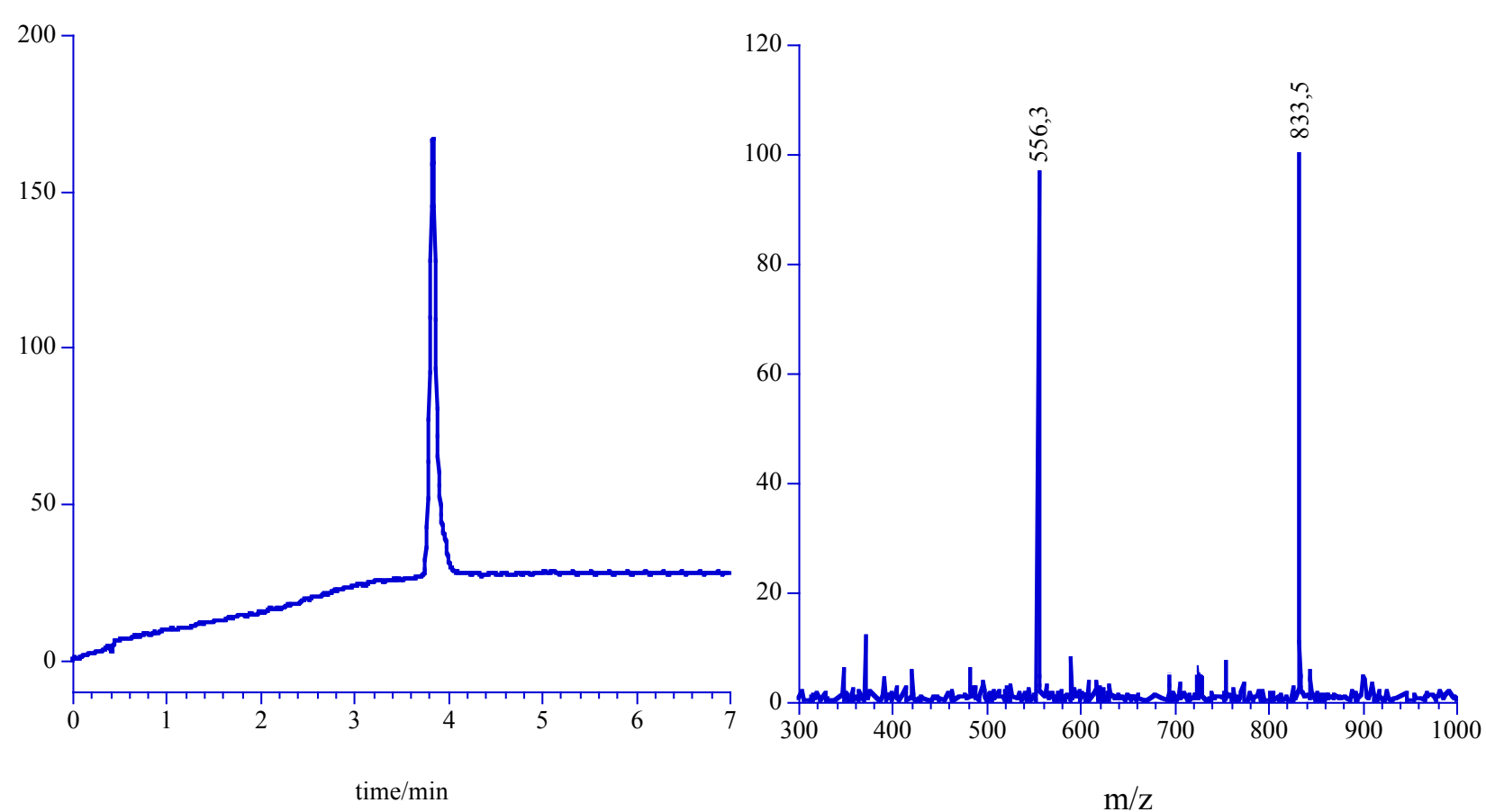

Figure S23. A) ${ }^{1} \mathrm{H}-\mathrm{NMR}$ spectra in $\mathrm{D}_{2} \mathrm{O}$ of $\operatorname{TmArg}_{2}(\mathrm{Man})_{2}$. B) RP-HPLC [Agilent SB-C18 column, $\mathrm{H}_{2} \mathrm{O}(0.1 \%$ $\mathrm{TFA}) / \mathrm{CH}_{3} \mathrm{CN}(0.1 \%$ TFA) 95:5 $\rightarrow 5: 95(0 \rightarrow 5 \mathrm{~min})]\left(R_{\mathrm{t}} 3.8 \mathrm{~min}\right)$ and ESI-MS for $\operatorname{TmArg}_{2}(\mathrm{Man})_{2}$. 
A)

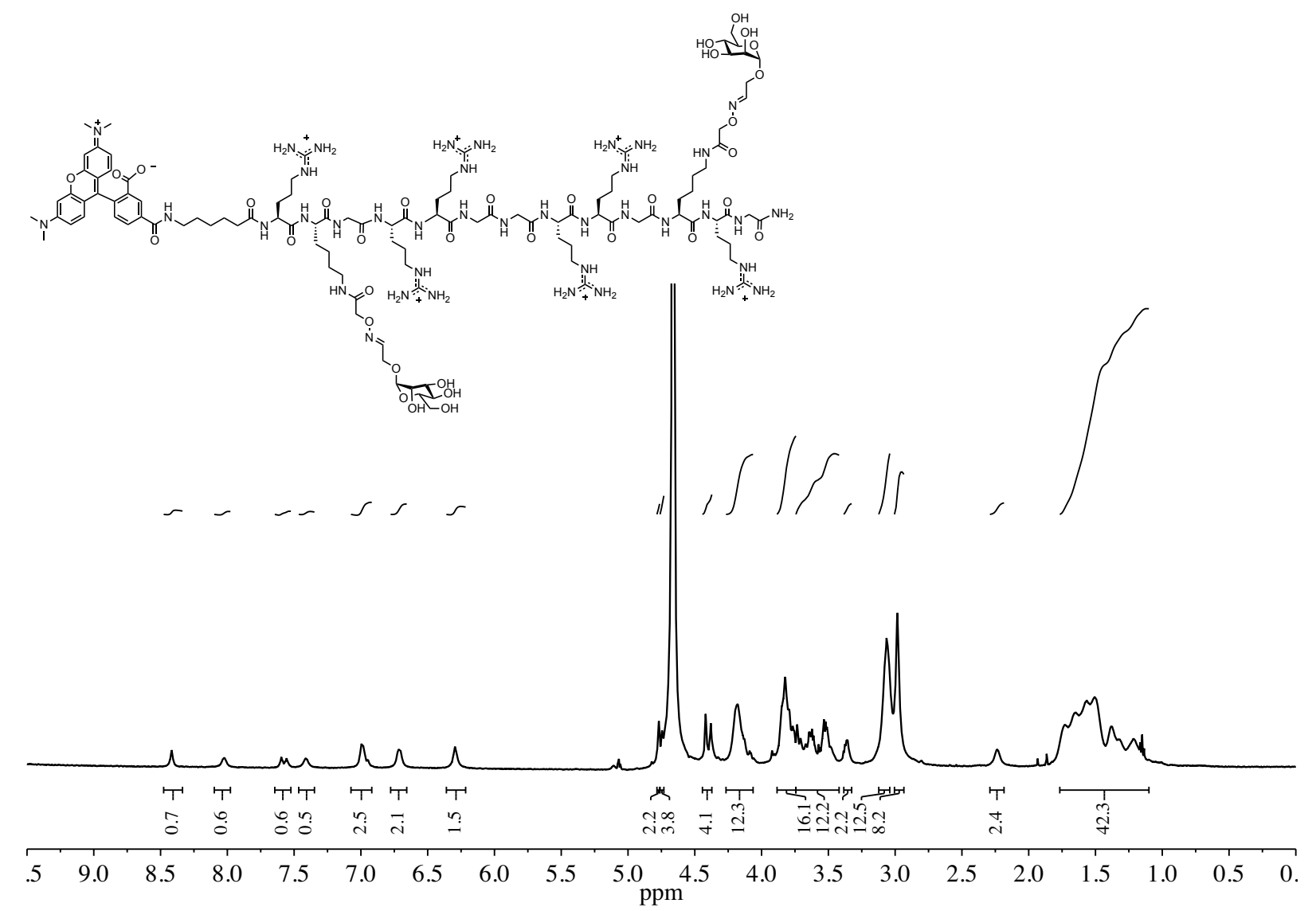

B) $\underset{\text { Abs } 222 \mathrm{~nm}}{\text { (a. u.) }}$
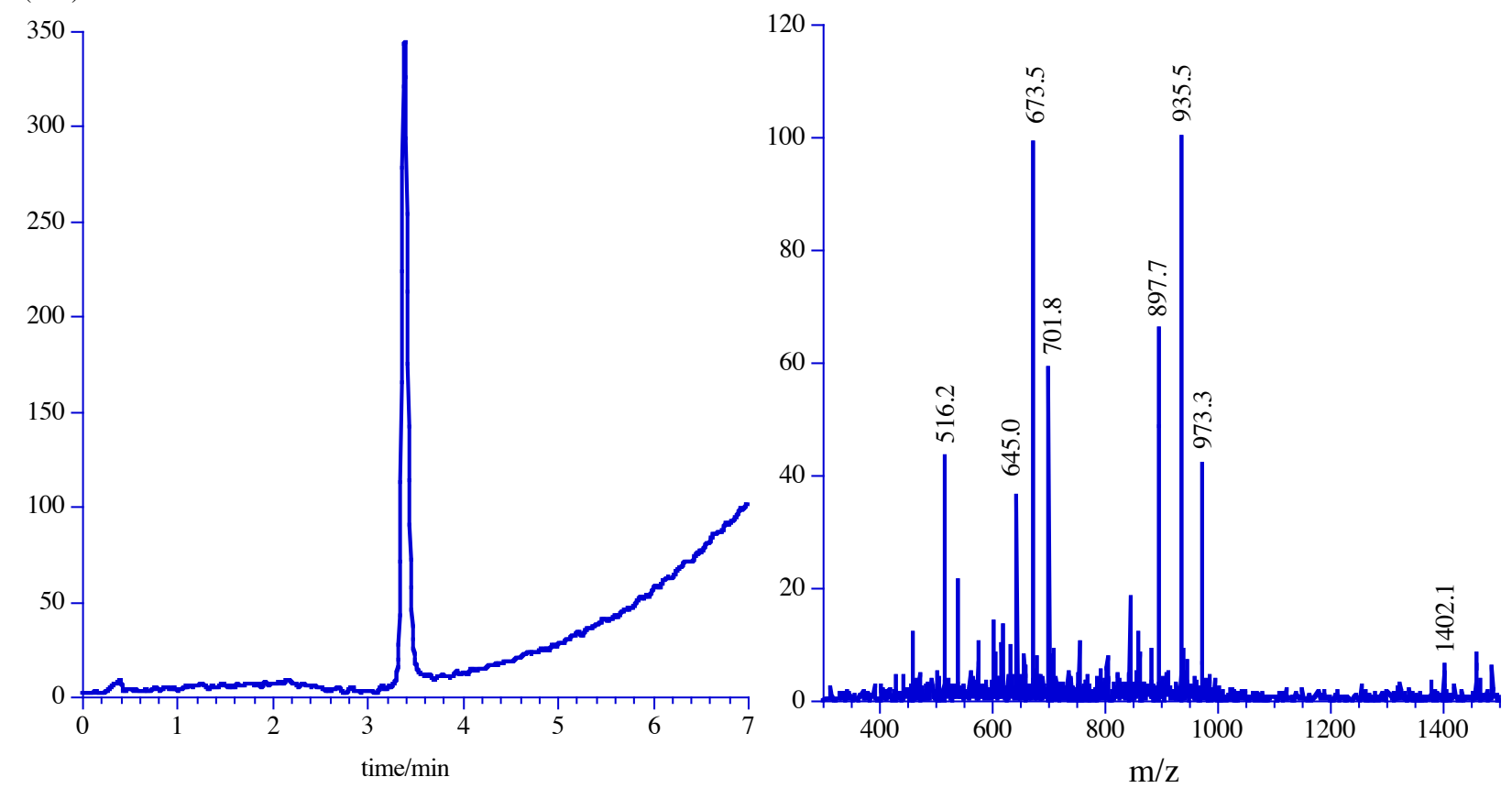

Figure S24. A) ${ }^{1} \mathrm{H}-\mathrm{NMR}$ spectra in $\mathrm{D}_{2} \mathrm{O}$ of $\mathrm{TmArg}_{6} \mathrm{Gly}_{5}(\mathrm{Man})_{2}$. B) RP-HPLC [Agilent SB-C18 column, $\mathrm{H}_{2} \mathrm{O}$ $(0.1 \% \mathrm{TFA}) / \mathrm{CH}_{3} \mathrm{CN}(0.1 \% \mathrm{TFA})$ 95:5 $\left.\rightarrow 5: 95(0 \rightarrow 5 \mathrm{~min})\right]\left(R_{\mathrm{t}} 3.4 \mathrm{~min}\right)$ and ESI-MS for TmArg ${ }_{6} \mathrm{Gly}_{5}(\mathrm{Man})_{2}$. 
A)
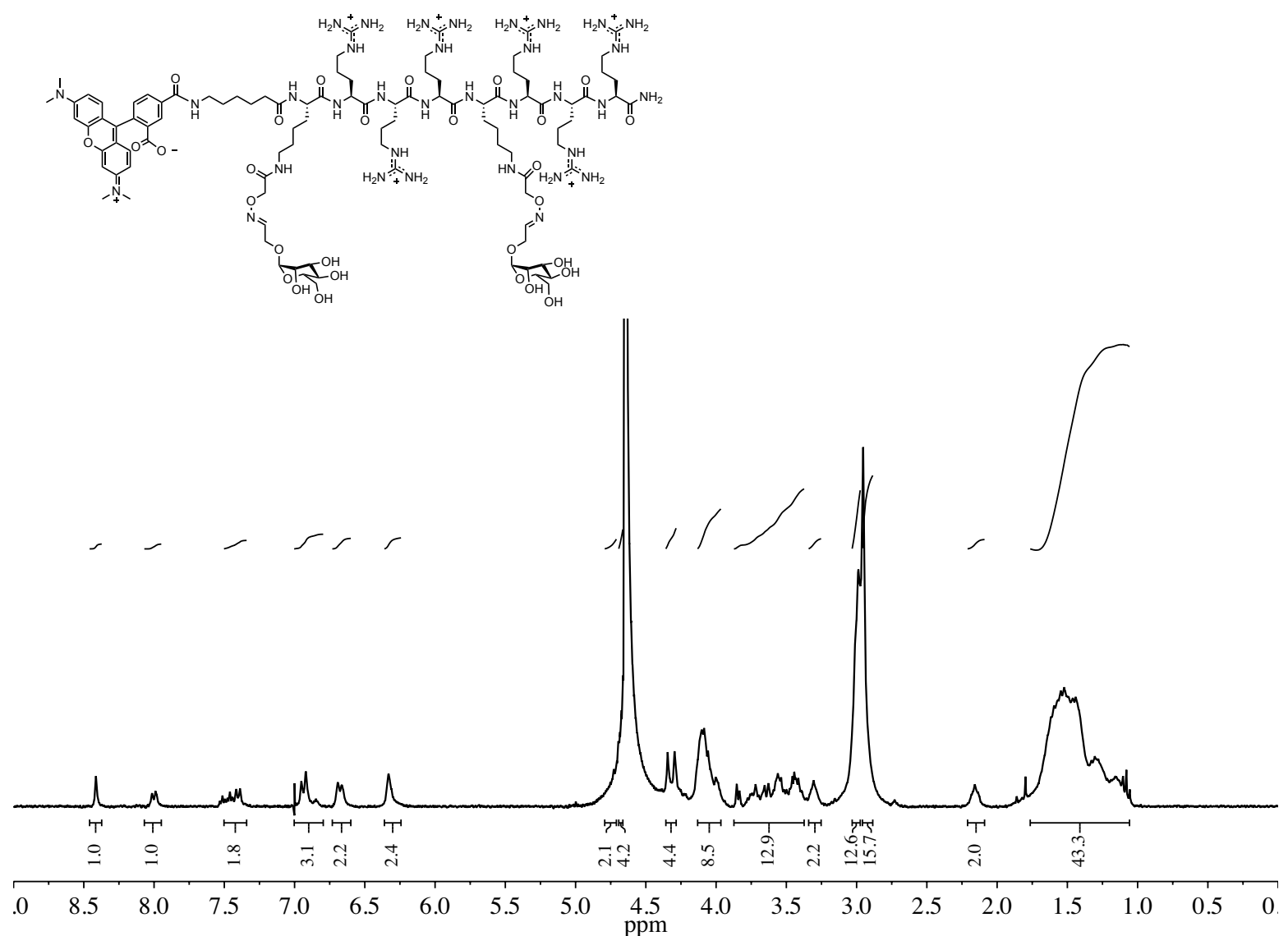

B)

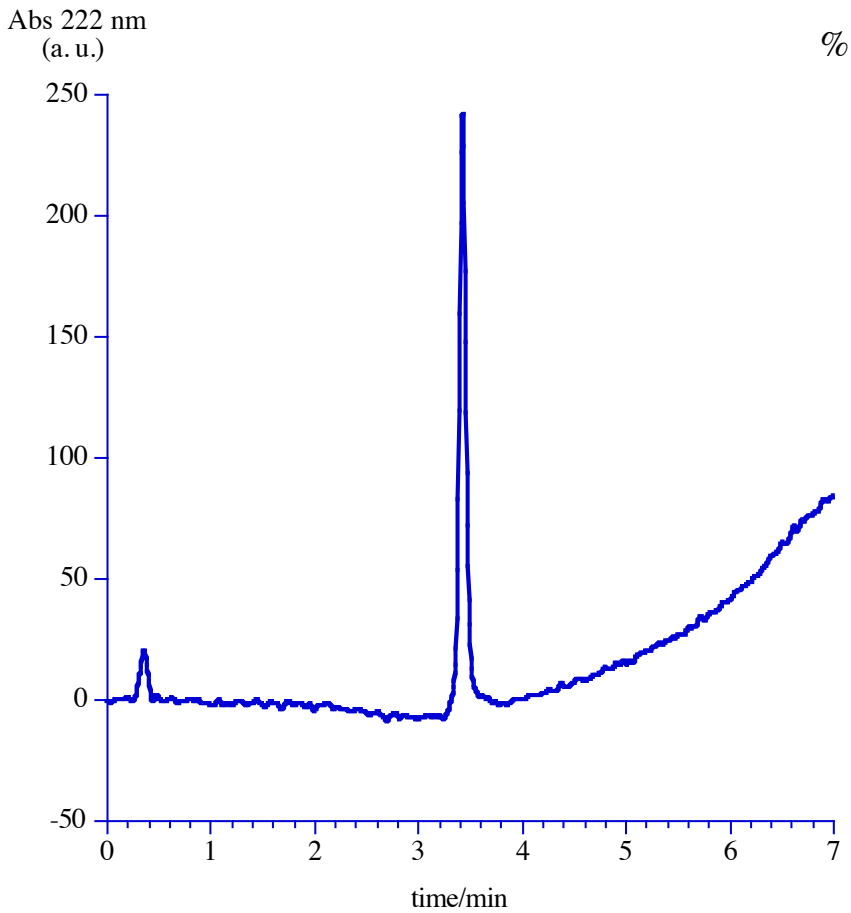

$\%$ Abundance

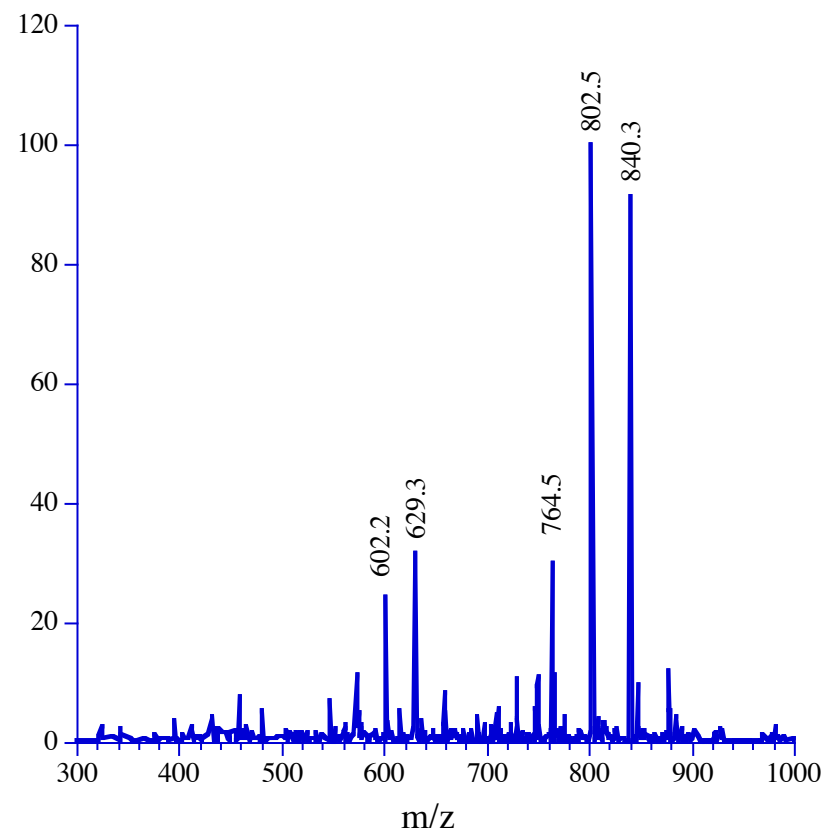

Figure S25. A) ${ }^{1} \mathrm{H}-\mathrm{NMR}$ spectra in $\mathrm{D}_{2} \mathrm{O}$ of $\operatorname{TmArg}_{6}(\mathrm{Man})_{2}$. B) RP-HPLC [Agilent SB-C18 column, $\mathrm{H}_{2} \mathrm{O}(0.1 \%$ TFA) $/ \mathrm{CH}_{3} \mathrm{CN}(0.1 \%$ TFA) 95:5 $\rightarrow 5: 95(0 \rightarrow 5 \mathrm{~min})]\left(R_{\mathrm{t}} 3.4 \mathrm{~min}\right)$ and ESI-MS for $\operatorname{TmArg}_{6}(\mathrm{Man})_{2}$. 
A)

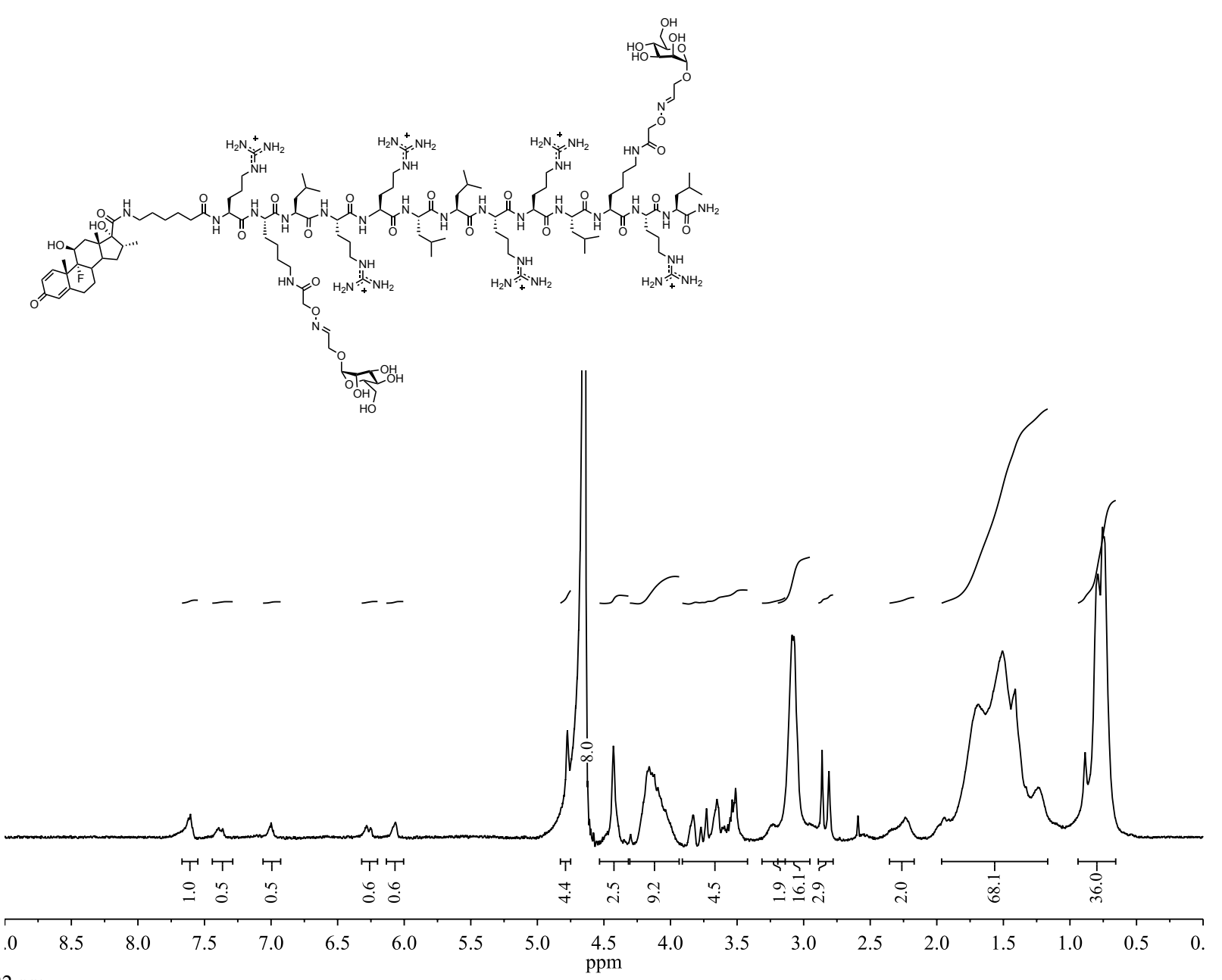

\begin{abstract}
B)
\end{abstract} Abs $222 \mathrm{~nm}$
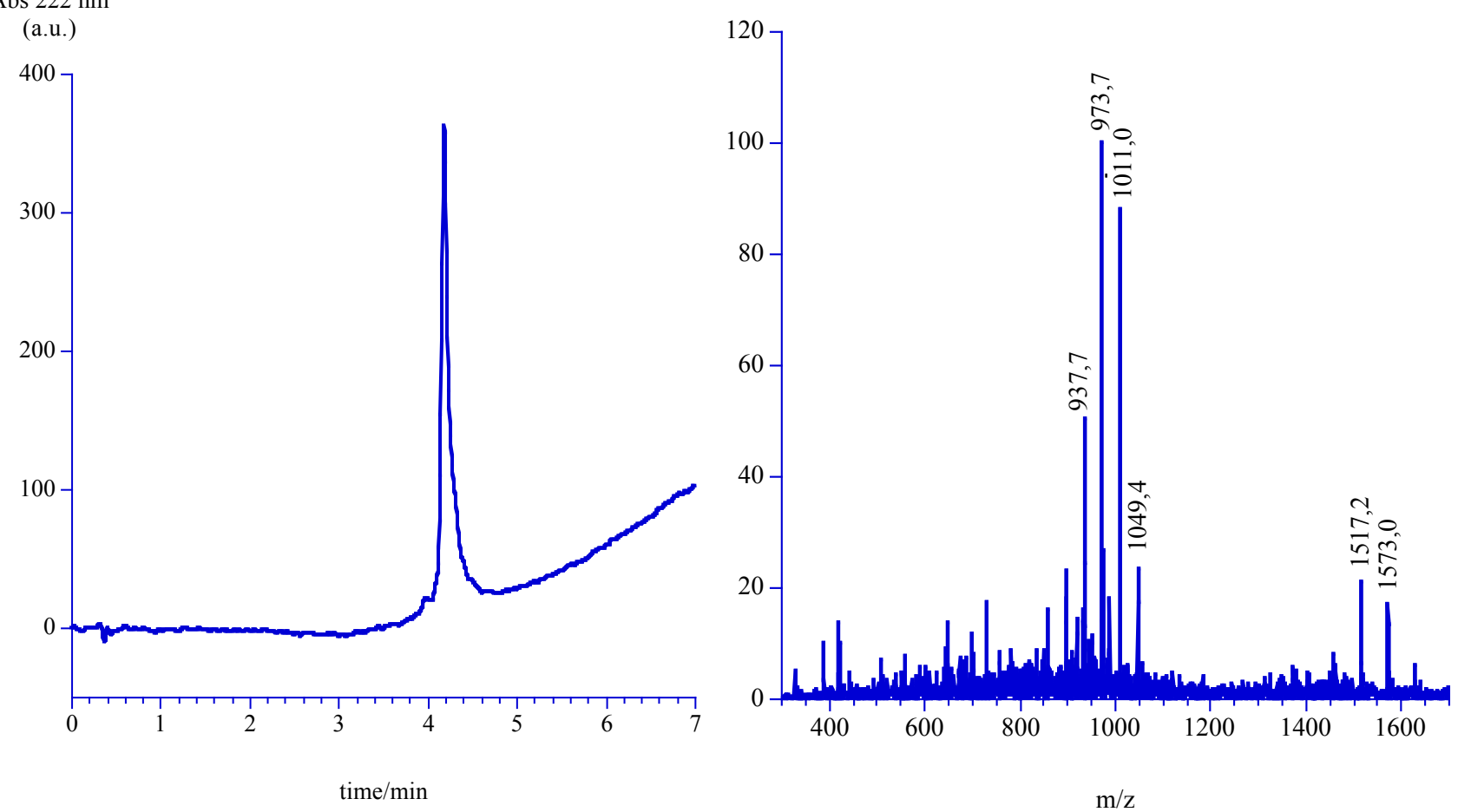

Figure S26. A) ${ }^{1} \mathrm{H}-\mathrm{NMR}$ spectra in $\mathrm{D}_{2} \mathrm{O}$ of DexP(Man) $)_{2}$. B) RP-HPLC [Agilent SB-C18 column, $\mathrm{H}_{2} \mathrm{O}(0.1 \%$ TFA $) / \mathrm{CH}_{3} \mathrm{CN}(0.1 \%$ TFA) 95:5 $\rightarrow 5: 95(0 \rightarrow 5 \mathrm{~min})]\left(R_{\mathrm{t}} 4.2 \mathrm{~min}\right)$ and ESI-MS for DexP(Man $)_{2}$. 


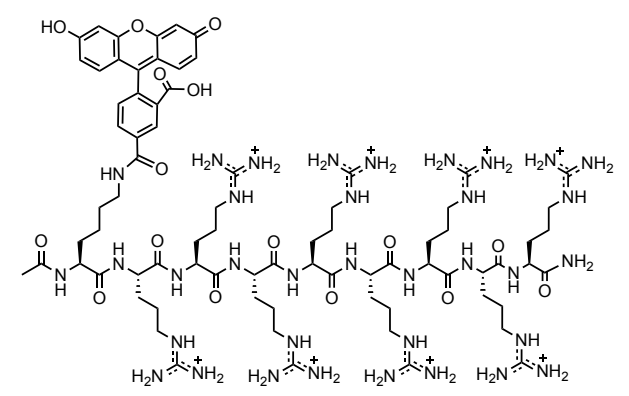

A)

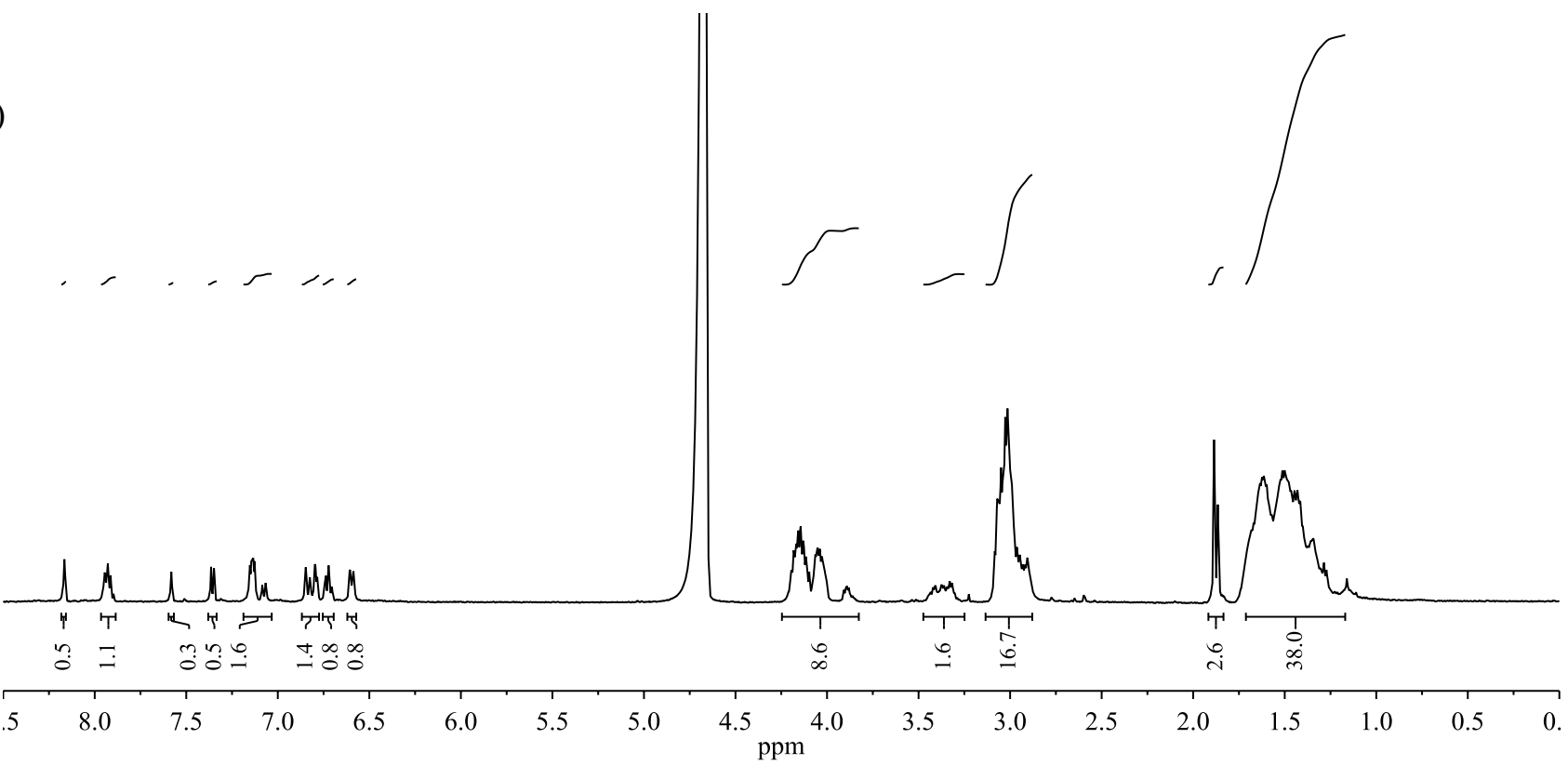

Abs $222 \mathrm{~nm}$

B) (a.u.)
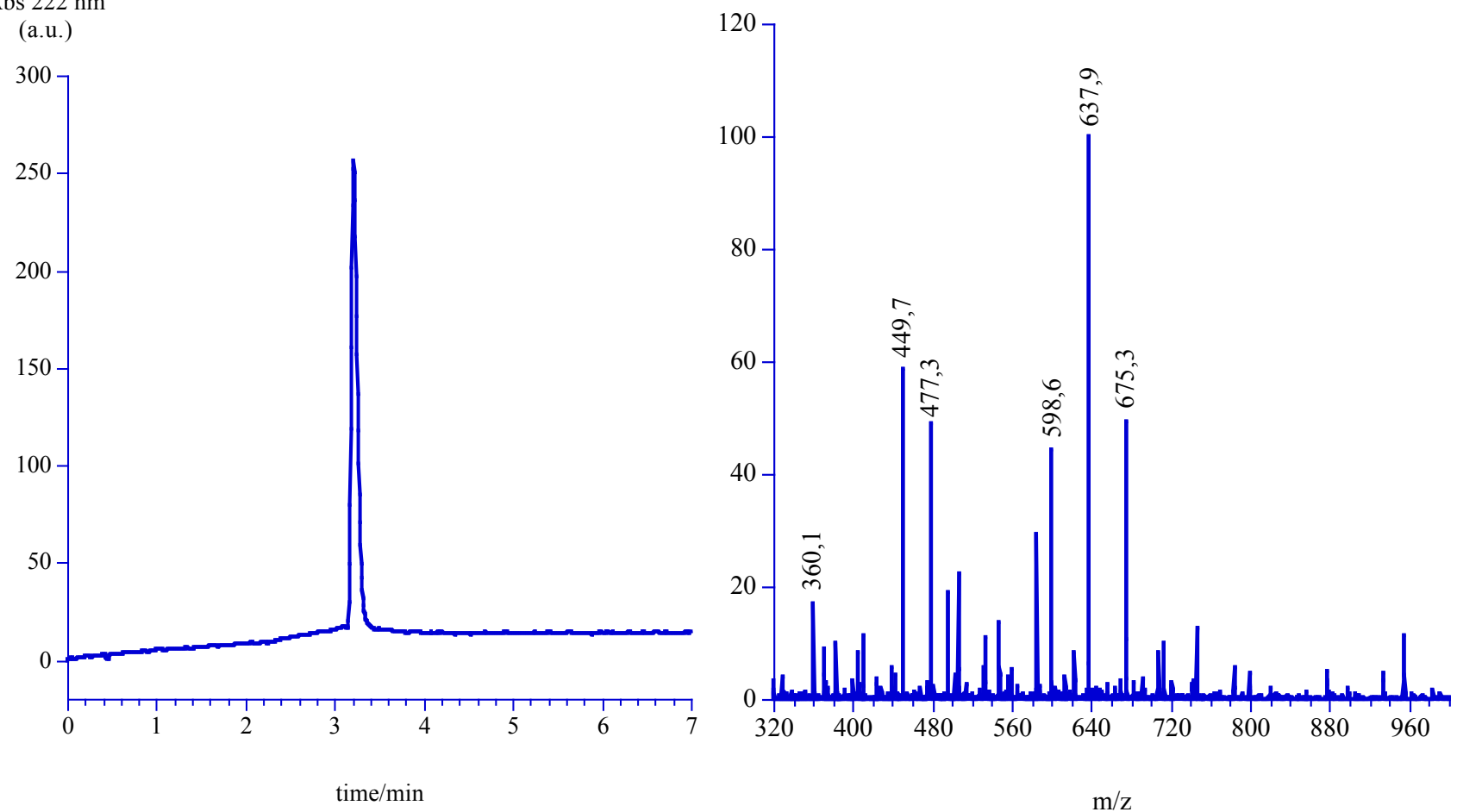

Figure S27. A) ${ }^{1} \mathrm{H}-\mathrm{NMR}$ spectra in $\mathrm{D}_{2} \mathrm{O}$ of $\mathrm{CFArg}_{8}$. B) RP-HPLC [Agilent SB-C18 column, $\mathrm{H}_{2} \mathrm{O}(0.1 \%$ TFA)/ $\mathrm{CH}_{3} \mathrm{CN}(0.1 \%$ TFA) 95:5 $\rightarrow 5: 95(0 \rightarrow 5 \mathrm{~min})]\left(R_{\mathrm{t}} 3.2 \mathrm{~min}\right)$ and ESI-MS for CFArg 8 . 


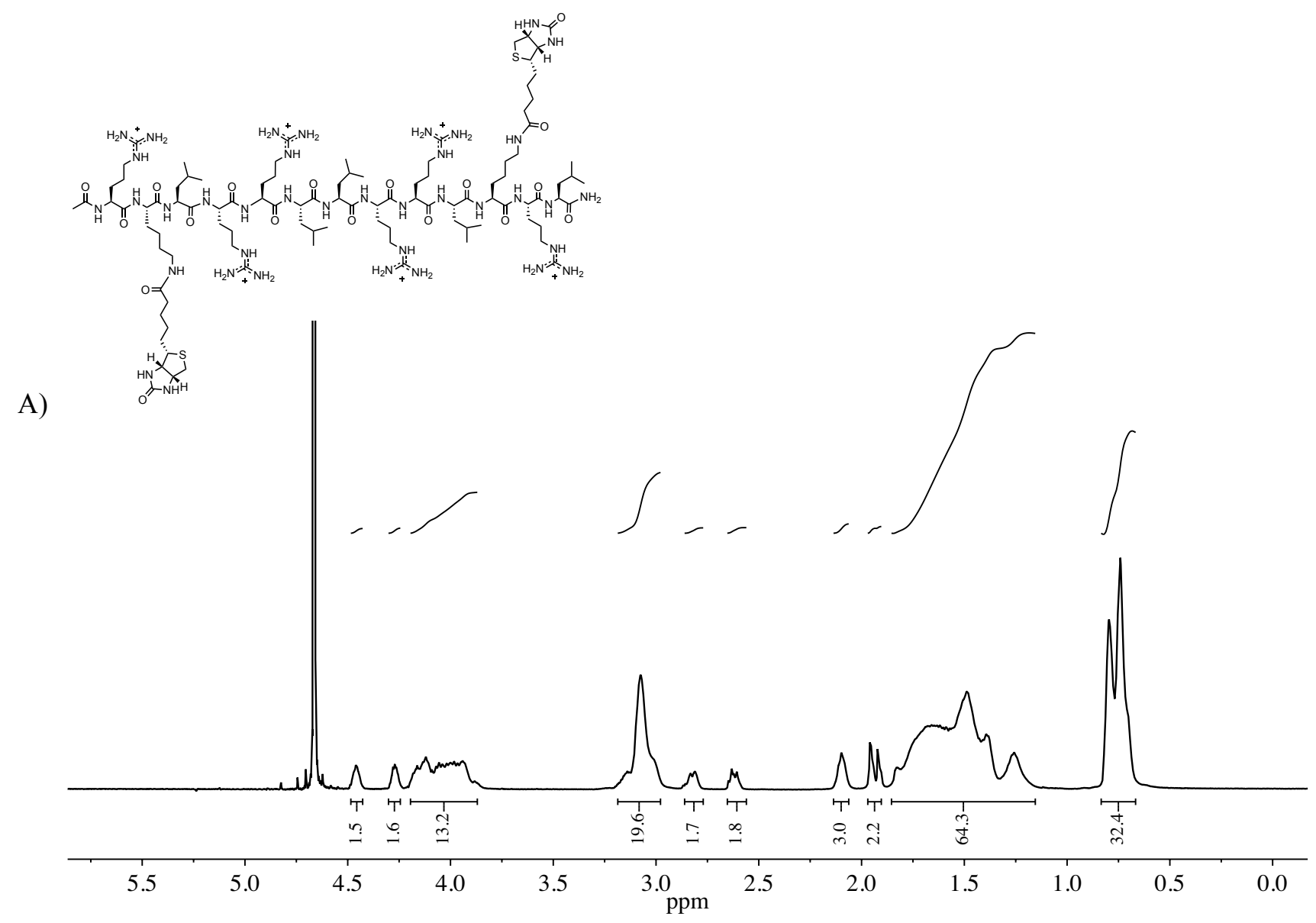

B)
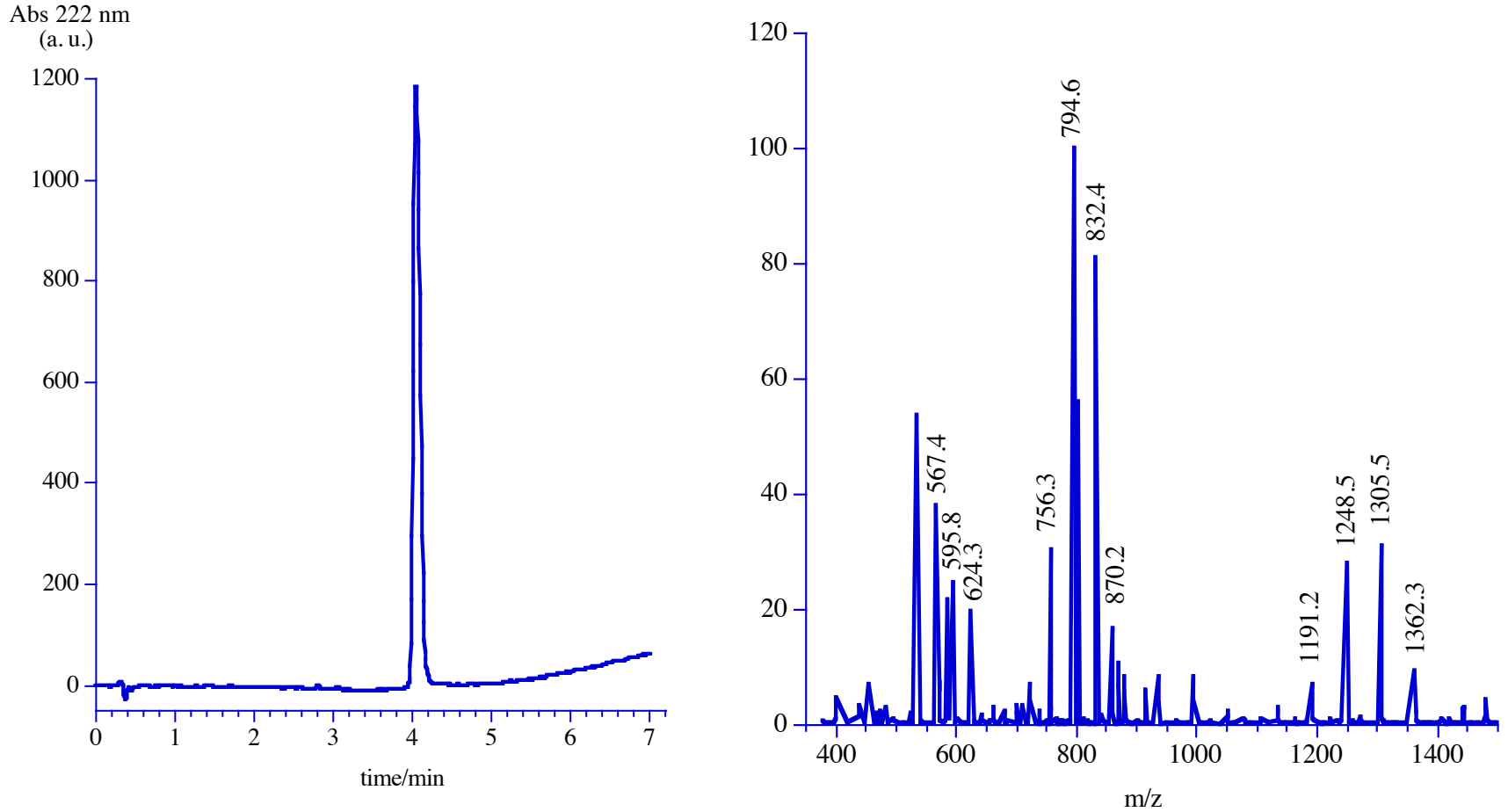

Figure S28. A) ${ }^{1} \mathrm{H}-\mathrm{NMR}$ spectra in $\mathrm{D}_{2} \mathrm{O}$ of $\left.\mathrm{AcP}(\mathrm{Biot})_{2} \mathrm{~B}\right)$ RP-HPLC [Agilent SB-C18 column, $\mathrm{H}_{2} \mathrm{O}(0.1 \%$ TFA $) /$ $\mathrm{CH}_{3} \mathrm{CN}(0.1 \% \mathrm{TFA})$ 95:5 $\left.\rightarrow 5: 95(0 \rightarrow 5 \mathrm{~min})\right]\left(R_{\mathrm{t}} 4.1 \mathrm{~min}\right)$ and ESI-MS for $\mathrm{AcP}(\mathrm{Biot})_{2}$. 

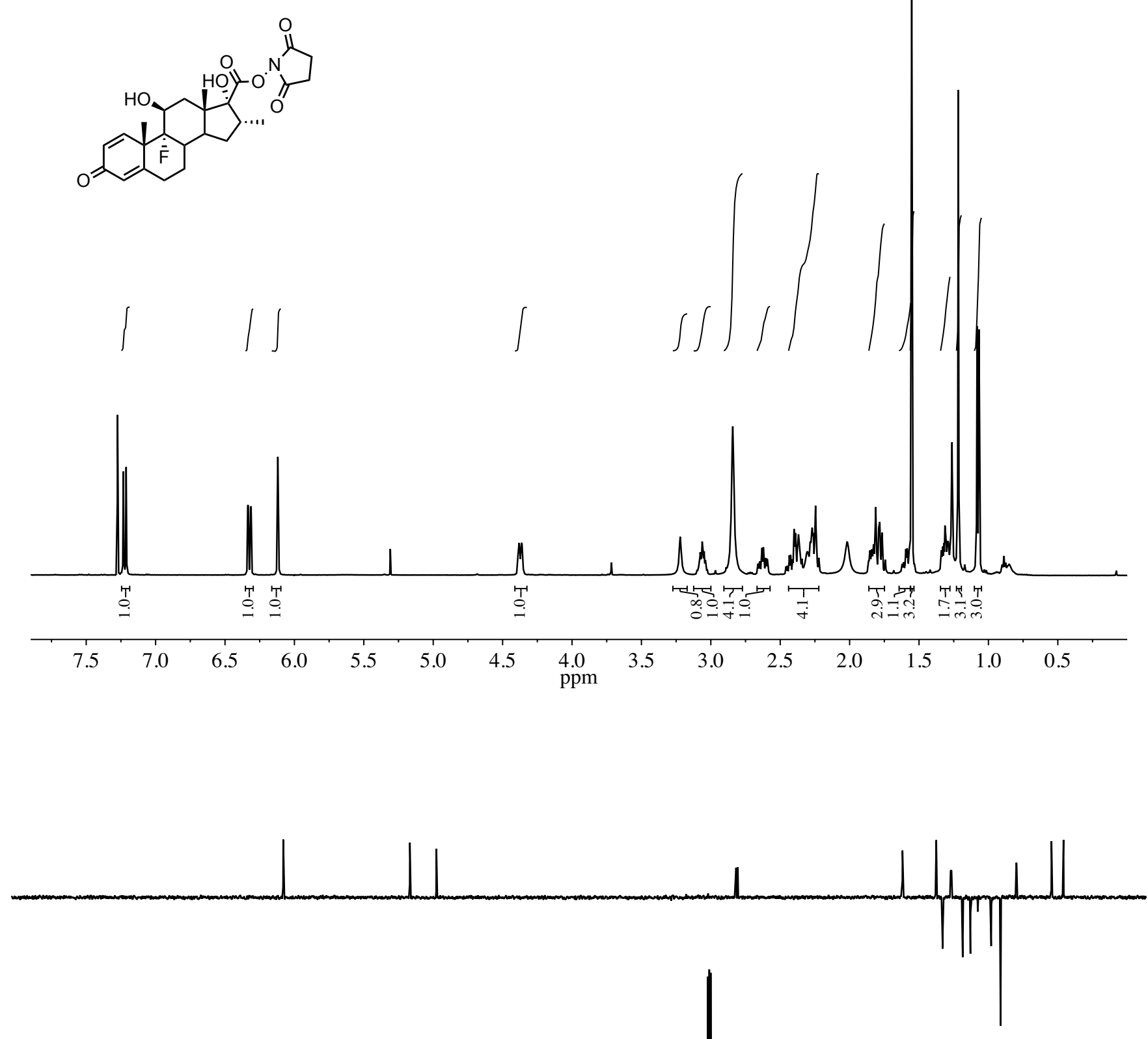

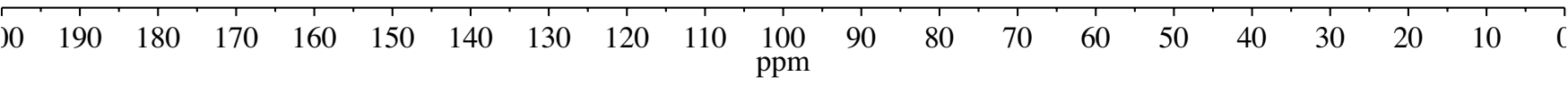

Figure S29. ${ }^{1} \mathrm{H}-\mathrm{NMR}$, DEPT and ${ }^{13} \mathrm{C}-\mathrm{NMR}$ spectra in $\mathrm{CDCl}_{3}$ of DexNHS. 


\section{Supporting References}

[1] W. Yao, Y. Jiao, J. Luo, M. Du, L. Zong, Int. J. Biol. Macromol. 2012, 50, 821-825.

[2] M. V Govindan, B. Manz, 1980, 53, 47-53.

[3] R. Behrendt, P. White, J. Offer, J. Pept. Sci. 2016, 22, 4-27.

[4] C. Kay, O. E. Lorthioir, N. J. Parr, M. Congreve, S. C. McKeown, J. J. Scicinski, S. V Ley, Biotechnol. Bioeng. 2000, 71, 110-8.

[5] T. Holm, H. Johansson, P. Lundberg, M. Pooga, M. Lindgren, U. Langel, Nat. Protoc. 2006, 1, 1001-5.

[6] J. M. Holub, J. R. Larochelle, J. S. Appelbaum, A. Schepartz, Biochemistry 2013, 52, 9036-46.

[7] K. L. Carey, S. A. Richards, K. M. Lounsbury, I. G. Macara, J. Cell Biol. 1996, 133, 985-96.

[8] A. E. Carpenter, T. R. Jones, M. R. Lamprecht, C. Clarke, I. H. Kang, O. Friman, D. A. Guertin, J. H. Chang, R. A. Lindquist, J. Moffat, et al., Genome Biol. 2006, 7, R100.

[9] R Core Team, R: A Language and Environment for Statistical Computing, 2015. 